NISTIR 85-3273-12

(Rev. 4/97)

\title{
Energy Price Indices and Discount Factors for Life-Cycle Cost Analysis - April 1997
}

Annual Supplement to

iilsT Hanúbook 135 and

NBS Special Publication 709

QC

NO.85-3273

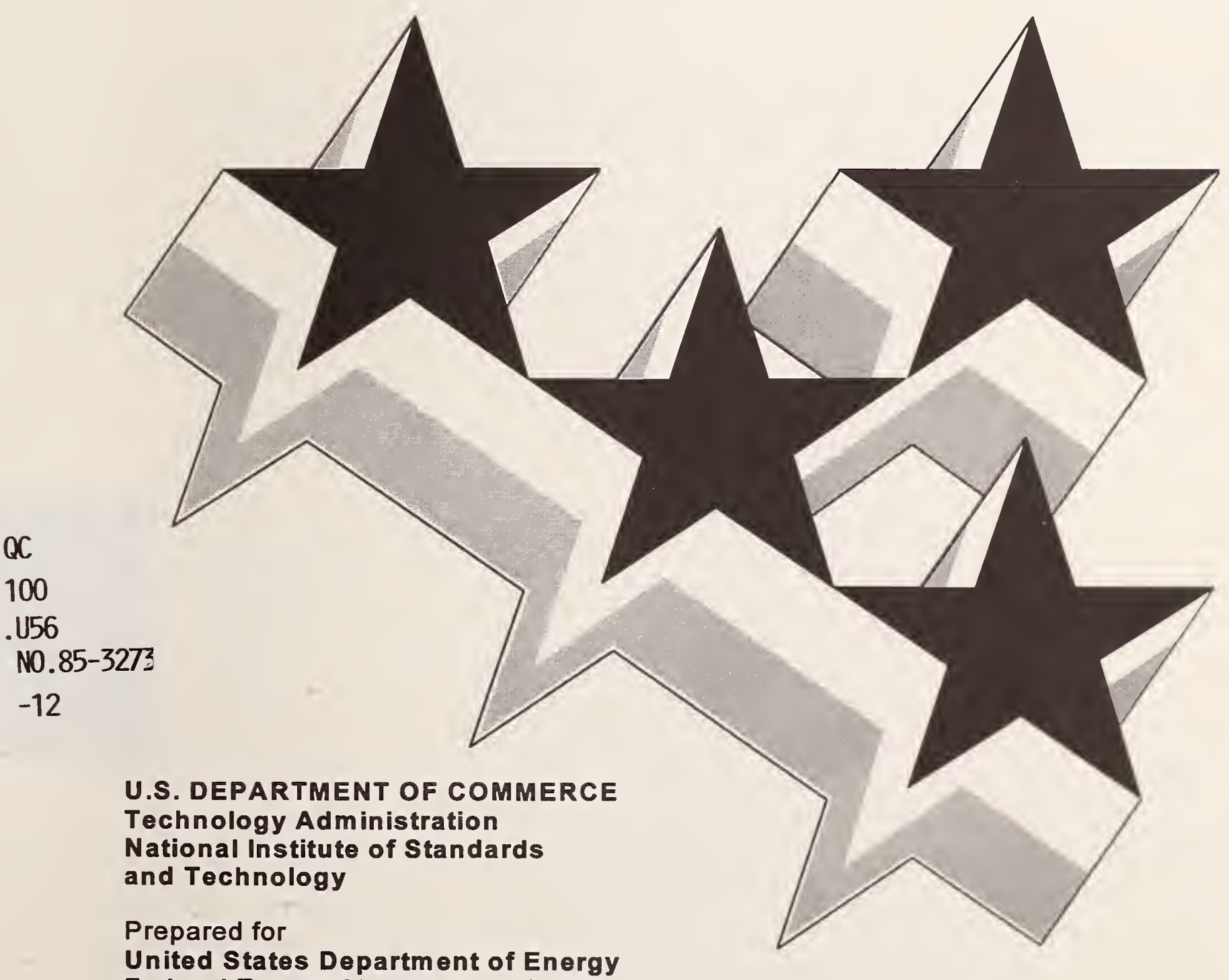

United States Department of Energy

Sieglinde K. Fuller

Federal Energy Management Program 



\section{ENERGY PRICE INDICES AND DISCOUNT FACTORS FOR LIFE-CYCLE COST ANALYSIS}

Annual Supplement to NIST Handbook 135 and NBS Special Publication 709

\section{April 1, 1997 to March 31, 1998}

Data for the Federal Methodology for Life-Cycle Cost Analysis, Title 10, CFR, Part 436, Subpart A;

and for the Energy Conservation Mandatory Performance Standards for New

Federal Residential Buildings, Title 10, CFR, Part 435

Sieglinde K. Fuller

Office of Applied Economics

\section{April 1997}

Building and Fire Research Laboratory

National Institute of Standards and Technology

Gaithersburg, Maryland 20899

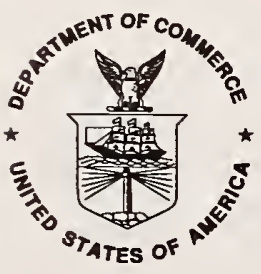

\section{U.S. Department of Commerce}

William A. Daley, Secretary

Technology Administration

Mary L. Good, Under Secretary for Technology

National Institute of Standards and Technology

Robert E. Hebner, Acting Director
Sponsored by:

The Federal Energy Management Program

U.S. Department of Energy

Washington, DC 20585 



\begin{abstract}
This is the April 1997 edition of energy price indices and discount factors for performing life-cycle cost analyses of energy and water conservation and renewable energy projects in federal facilities. It will be effective from April 1, 1997 to March 31, 1998. This publication supports the federal life-cycle costing methodology by updating the energy price projections and discount factors that are described, explained, and illustrated in NIST Handbook 135 (HB 135, Life-Cycle Costing Manual for the Federal Energy Management Program.) It supports private-sector life-cycle cost analysis by updating the energy price indices that are described, explained, and illustrated in NBS Special Publication 709 (SP 709). It also supports the Energy Conservation Mandatory Performance Standards for New Federal Residential Buildings (10 CFR 435) by providing a table of factors for updating appliance label values.
\end{abstract}




\section{PREFACE}

This is the April 1997 Annual Supplement to NIST Handbook 135, Life-Cycle Costing Manual for the Federal Energy Management Program. The annual supplement provides energy price indices and discount factors for use with the Federal Energy Management Program's procedures for life-cycle cost analysis, as established by the U.S. Department of Energy (DOE) in Subpart A of Part 436 of Title 10 of the Code of Federal Regulations (10 CFR Part 436, Subpart A), and amplified in NIST Handbook 135. These indices and factors are provided as an aid to implementing life-cycle cost evaluations of potential energy and water conservation and renewable energy investments in existing and new federally owned and leased buildings.

Historically, the Annual Supplement to NIST Handbook 135 has been published in October of each year for use throughout the following fiscal year. However, the energy price projections from DOE's Energy Information Administration (EIA) that serve as the basis of much of this report are released in January, and the discount rates from the Office of Management and Budget (OMB) Circular A-94 are released in February, so that much of the data in this report are out of date after only a few months of their intended life. As a result, DOE has now requested that NIST produce this Annual Supplement as soon as practical after the necessary data are available. This edition was prepared in April to supersede the FY97 edition released in October 1996. In future years NIST will continue to produce the Annual Supplement in April. This Annual Supplement is intended for use from April 1, 1997 to March 31, 1998. The April 1997 edition of the NIST BLCC program and related NIST software for LCC analysis are being released at the same time as this Annual Supplement, for use over the same time period. These software products are discussed on the next page.

At the request of a number of users, DOS text files of both the underlying EIA energy price projections and the tables in this Annual Supplement have been made available by NIST. For information on obtaining these files, contact the author by e-mail at sieglinde.fuller@nist.gov.

The life-cycle costing methods and procedures as set forth in 10 CFR, Part 436, Subpart A, are to be followed by all federal agencies, unless specifically exempted, in evaluating the cost effectiveness of potential energy and water conservation and renewable energy investments in federally owned and leased buildings.

As called for by legislation, the National Institute of Standards and Technology has provided technical assistance to the U.S. Department of Energy in the development and implementation of life-cycle costing methods and procedures. This is the second of a three-volume set which together provide the methods, data, and computational tools for life-cycle cost analysis of federal energy projects.

Included in the three-volume set for federal life-cycle cost analysis are the following:

Life-Cycle Costing Manual for the Federal Energy Management Program, National Institute of Standards and Technology, Handbook 135 (1995).

The manual is a guide to understanding life-cycle costing and related methods of economic analysis as they are applied to federal decisions, especially those subject to DOE 10 CFR 436 rules related to the economic analysis of energy and water conservation projects and renewable resource projects. It describes the required procedures and assumptions, defines and explains how to apply and interpret economic performance measures, gives examples of federal decision problems and their solutions, explains how to use the energy price indices and discount factors that are updated annually in the supplement, and 
provides worksheets and other computational aids and instructions for calculating the required measures. The 1995 edition of Handbook 135 is a complete revision of the 1987 edition, with updated information on the FEMP LCC requirements of 10 CFR 436.

(2) Energy Price Indices and Discount Factors for Life-Cycle Cost Analysis, Annual Supplement to NIST Handbook 135 and NBS Special Publication 709, National Institute of Standards and Technology, NISTIR 85-3273.

This report, which is updated annually, provides the current DOE discount rate, projected energy price indices, and corresponding discount factors needed to estimate the present value of future energy and nonenergy project-related costs. The energy price indices were provided by the Energy Information Administration of the U.S. Department of Energy. Request the latest edition when ordering. (This is the report that you are holding in your hands.)

NIST "Building Life-Cycle Cost" (BLCC) Computer Program, National Institute of Standards and Technology, NISTIR 4481 (User's Guide dated January 1995). Use version 4.5-97 for the period from April 1, 1997 to March 31, 1998.

The NIST Building Life-Cycle Cost program provides comprehensive economic analysis capabilities for the evaluation of proposed capital investments that are expected to reduce the long-term operating costs of buildings and building systems. The BLCC program is designed to run on IBM PC and compatible microcomputers in a MS-DOS environment. The BLCC program computes the LCC for project alternative, compares project alternatives in order to determine which has the lowest LCC, performs annual cash flow analysis, and computes net savings, the savings-to-investment ratio (SIR), and adjusted internal rate of return (AIRR) for project alternatives over their designated study period. BLCC can be used to perform economic analysis of capital investment projects undertaken by federal, state, and local government agencies, as well as by the private sector. BLCC (version 4.5-97) uses the same DOE/EIA energy price projections included in the Annual Supplement to Handbook 135. In its application to federal energy conservation and renewable energy projects, BLCC is consistent with NIST Handbook 135 (see \#1 above). In its application to non-energy projects, BLCC is consistent with OMB Circular A-94. In its application to private-sector and non-federal public-sector projects, BLCC is consistent with ASTM standards for building economics.

Included on the BLCC disk is the QuickBLCC program, a simplified version of BLCC which can be used to set up an analysis of multiple project alternatives. Also included is the DISCOUNT program (version 3.6-97), which can calculate present value, future value, and annual value factors for any discount rate and study period. DISCOUNT can access the DOE energy price projections included on the BLCC disk to compute the UPV* factors needed for federal LCC analyses of energy projects, consistent with the factors included in this report. Two additional programs, ERATES (for use with complex electricity rate schedules) and EMISS (for generating local air pollution emission factors in BLCC analyses) are also available with BLCC.

The U.S. Department of Energy was directed by legislation and executive order to make available to the private sector the methods, procedures, and related aids developed for federal use. In response to this directive, the National Institute of Standards and Technology, under sponsorship of the U.S. Department of Energy, published a life-cycle costing book for use by the private sector entitled Comprehensive Guide for Least-Cost Energy Decisions, NBS SP 709 (January 1987). The private sector guide is supported by the data provided here, as well as by the BLCC computer program. The BLCC program supersedes the 
NBSLCC program which is documented in SP 709. BLCC provides LCC computational support for private sector projects as well as for federal projects.

To order any of these publications and software products call:

Energy Efficiency and Renewable Energy Clearing House (800) DOE-EREN (800-363-3732)

or write or fax your order to:

U.S. Department of Energy

Federal Energy Management Program, EE-90

1000 Independence Avenue, S.W.

Washington, DC 20585-0121

Fax: 202-586-3000

BLCC and related LCC software may also be purchased from the following vendors:

FlowSoft

5 Oak Forest Court

Saint Charles, MO 63303

(314) 441-1022

Energy Information Services

P.O. Box 381

St. Johnsbury, VT 05819-0381

(802) 748-5148

or downloaded via Internet from the FEMP home page at http://www.eren.doe.gov/femp (click on icons Technical Assistance - Analytical Software Tools).

Workshops on the life-cycle costing method and energy analysis are conducted at locations around the country each year. The workshops include training and software for both BLCC and an energy analysis computer program called "A Simplified Energy Analysis Method" (ASEAM). A schedule of workshops can be obtained from DOE/FEMP at (202) 586-8017, Fax (202) 586-3000.

Three video training films in a series entitled "Least-Cost Energy Decisions for Buildings" have been prepared by NIST. These films include "Introduction to Life-Cycle Costing," "Uncertainty and Risk," and "Choosing Economic Evaluation Methods." The video films and companion workbooks can be ordered from Video Transfer, Inc., 5709-B Arundel Avenue, Rockville, MD 20852, Telephone (301) 881-0270, Fax (301) 770-9131.

Further information on the Federal Energy Management Program can be obtained from the Federal Energy Management Program Staff, Office of the Assistant Secretary for Energy Efficiency and Renewable Energy, U.S. Department of Energy. Please direct communication to: FEMP, CE 10.1, U.S. Department of Energy, 1000 Independence Avenue, SW, Washington, DC 20585. 


\section{ACKNOWLEDGMENTS}

The author wishes to thank Mr. Theodore Collins of the Federal Energy Management Program of the U.S. Department of Energy (DOE) for his continued support and direction of this work. Appreciation is extended to Mr. Art Andersen, Director of the Energy Demand and Integration Division, and Susan Shaw, Chief, and Paul Condis of the National Energy Modeling System Branch, DOE Energy Information Administration, for providing the energy price projections upon which this report is based. I am also grateful to Stephen R. Petersen, who previously prepared this publication, for his help and to Laurene Linsenmayer for her assistance in editing and producing this document. 


\section{CONTENTS}

Page

ABSTRACT $\ldots \ldots \ldots \ldots \ldots \ldots \ldots \ldots \ldots \ldots \ldots \ldots \ldots \ldots \ldots \ldots \ldots \ldots \ldots \ldots \ldots$

PREFACE $\ldots \ldots \ldots \ldots \ldots \ldots \ldots \ldots \ldots \ldots \ldots \ldots \ldots \ldots \ldots \ldots \ldots \ldots \ldots \ldots \ldots \ldots \ldots \ldots$

ACKNOWLEDGMENTS $\ldots \ldots \ldots \ldots \ldots \ldots \ldots \ldots \ldots \ldots \ldots \ldots \ldots \ldots \ldots \ldots$ vii

LIST OF TABLES $\ldots \ldots \ldots \ldots \ldots \ldots \ldots \ldots \ldots \ldots \ldots \ldots \ldots \ldots \ldots \ldots \ldots$

ABBREVIATIONS $\ldots \ldots \ldots \ldots \ldots \ldots \ldots \ldots \ldots \ldots \ldots \ldots \ldots \ldots \ldots \ldots \ldots \ldots \ldots \ldots \ldots \ldots$

INTRODUCTION $\ldots \ldots \ldots \ldots \ldots \ldots \ldots \ldots \ldots \ldots \ldots \ldots \ldots \ldots \ldots \ldots \ldots \ldots$

PART I: TABLES FOR FEDERAL LIFE-CYCLE COST ANALYSIS $\ldots \ldots \ldots \ldots . \ldots . . .3$

A. Single Present Value and Uniform Present Value Factors for Non-Fuel Costs . . . . . . 3

B. Modified Uniform Present Value Factors for Fuel Costs $\ldots \ldots \ldots \ldots \ldots \ldots \ldots \ldots \ldots$

B.1. FEMP Modified Uniform Present Value Factors . . . . . . . . . . . . . . 14

B.2. OMB Modified Uniform Present Value Factors $\ldots \ldots \ldots \ldots \ldots \ldots \ldots$

C. Projected Average Fuel Price Indices and Escalation Rates (Real) $\ldots \ldots \ldots \ldots$

D. Factors for Updating Appliance Label Values $\ldots \ldots \ldots \ldots \ldots \ldots \ldots \ldots \ldots$

PART II: ENERGY PRICE INDICES FOR PRIVATE SECTOR LCC ANALYSIS . . . . . . 44 


\section{LIST OF TABLES}

Page

A-1. $\quad$ SPV factors for finding the present value of future single costs (non-fuel) $\ldots \ldots \ldots 6$

A-2. UPV factors for finding the present value of future annually recurring uniform costs (non-

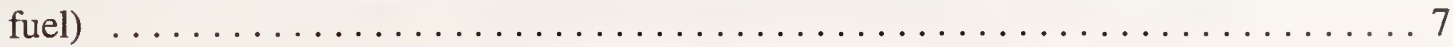

A-3a UPV* factors for finding the present value of annually recurring costs changing at at a constant escalation rate, DOE discount rate $(3.8 \%) \ldots \ldots \ldots \ldots \ldots$

A-3b UPV* factors for finding the present value of annually recurring costs changing at at a constant escalation rate, OMB short-term discount rate $(3.4 \%) \ldots \ldots \ldots$

A-3c UPV* factors for finding the present value of annually recurring costs changing at at a constant escalation rate, $\mathrm{OMB}$ long-term discount rate $(3.6 \%) \ldots \ldots \ldots \ldots$

Ba-1. $\quad$ FEMP UPV ${ }^{*}$ discount factors adjusted for fuel price escalation, by end-use sector and fuel type. Discount Rate $=3.8 \%$ (DOE). Census Region 1 (Connecticut, Maine, Massachusetts, New Hampshire, New Jersey, New York, Pennsylvania, Rhode Island, Vermont) . . 15

Ba-2. $\quad$ FEMP UPV* discount factors adjusted for fuel price escalation, by end-use sector and fuel type. Discount Rate $=3.8 \%$ (DOE). Census Region 2 (Illinois, Indiana, Iowa, Kansas, Michigan, Minnesota, Missouri, Nebraska, North Dakota, Ohio, South Dakota,

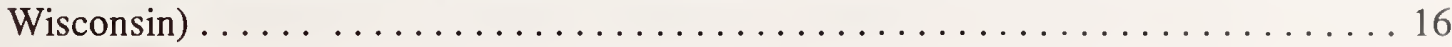

Ba-3. $\quad$ FEMP UPV* discount factors adjusted for fuel price escalation, by end-use sector and fuel type. Discount Rate $=3.8 \%$ (DOE). Census Region 3 (Alabama, Arkansas, Delaware, District of Columbia, Florida, Georgia, Kentucky, Louisiana, Maryland, Mississippi, North Carolina, Oklahoma, South Carolina, Tennessee, Texas, Virginia, West Virginia) . . . 17

Ba-4. FEMP UPV* discount factors adjusted for fuel price escalation, by end-use sector and fuel type. Discount Rate $=3.8 \%$ (DOE). Census Region 4 (Alaska, Arizona, California, Colorado, Hawaii, Idaho, Montana, Nevada, New Mexico, Oregon, Utah, Washington,

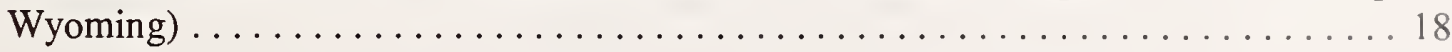

Ba-5. FEMP UPV* discount factors adjusted for fuel price escalation, by end-use sector and fuel

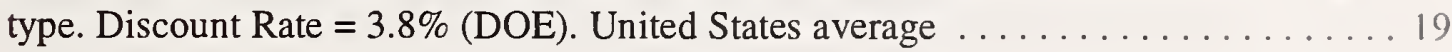

Bb-1. $\quad$ OMB UPV* discount factors adjusted for fuel price escalation, by end-use sector and fuel type. Discount Rate $=3.4 \%$ (years 1-10) and 3.6\% (years 11-30), (OMB Circular A-94). Census Region 1 (Connecticut, Maine, Massachusetts, New Hampshire, New Jersey, New York, Pennsylvania, Rhode Island, Vermont) 


\section{LIST OF TABLES (continued)}

Bb-2. $\quad$ OMB UPV* discount factors adjusted for fuel price escalation, by end-use sector and fuel type. Discount Rate $=3.4 \%$ (years 1-10) and 3.6\% (years 11-30), (OMB Circular A-94). Census Region 2 (Illinois, Indiana, Iowa, Kansas, Michigan, Minnesota, Missouri, Nebraska,

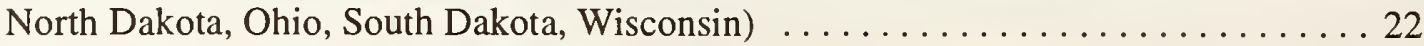

Bb-3. $\quad$ OMB UPV* discount factors adjusted for fuel price escalation, by end-use sector and fuel type. Discount Rate $=3.4 \%$ (years 1-10) and 3.6\% (years 11-30), (OMB Circular A-94). Census Region 3 (Alabama, Arkansas, Delaware, District of Columbia, Florida, Georgia, Kentucky, Louisiana, Maryland, Mississippi, North Carolina, Oklahoma, South Carolina, Tennessee, Texas, Virginia, West Virginia) ..................... 23

Bb-4. $\quad$ OMB UPV* discount factors adjusted for fuel price escalation, by end-use sector and fuel type. Discount Rate $=3.4 \%$ (years 1-10) and 3.6\% (years 11-30), (OMB Circular A-94). Census Region 4 (Alaska, Arizona, California, Colorado, Hawaii, Idaho, Montana, Nevada, New Mexico, Oregon, Utah, Washington, Wyoming) ................. 24

Bb-5. OMB UPV* discount factors adjusted for fuel price escalation, by end-use sector and fuel type. Discount Rate $=3.4 \%$ (years 1-10) and 3.6\% (years 11-30), (OMB Circular A-94).

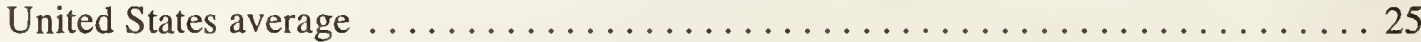

Ca-1. $\quad$ Projected fuel price indices (excluding general inflation) by end-use sector and fuel type. Census Region 1 (Connecticut, Maine, Massachusetts, New Hampshire, New Jersey, New York, Pennsylvania, Rhode Island, Vermont) $\ldots \ldots \ldots \ldots \ldots \ldots \ldots \ldots \ldots \ldots \ldots$

Ca-2. $\quad$ Projected fuel price indices (excluding general inflation) by end-use sector and fuel type. Census Region 2 (Illinois, Indiana, Iowa, Kansas, Michigan, Minnesota, Missouri, Nebraska, North Dakota, Ohio, South Dakota, Wisconsin) . . . . . . . . . . . . . . . 30

Ca-3. $\quad$ Projected fuel price indices (excluding general inflation) by end-use sector and fuel type. Census Region 3 (Alabama, Arkansas, Delaware, District of Columbia, Florida, Georgia, Kentucky, Louisiana, Maryland, Mississippi, North Carolina, Oklahoma, South Carolina, Tennessee, Texas, Virginia, West Virginia) .................. 32

Ca-4. $\quad$ Projected fuel price indices (excluding general inflation) by end-use sector and fuel type. Census Region 4 (Alaska, Arizona, California, Colorado, Hawaii, Idaho, Montana, Nevada, New Mexico, Oregon, Utah, Washington, Wyoming) ............... 34

Ca-5. Projected fuel price indices (excluding general inflation) by end-use sector and fuel type.

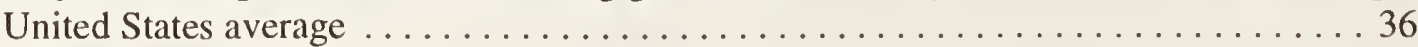

Cb-1. Projected average fuel price escalation rates (excluding general price inflation), by end-use sector and fuel type. Census Region 1 (Connecticut, Maine, Massachusetts, New Hampshire, New Jersey, New York, Pennsylvania, Rhode Island, Vermont) . . . . . . . . . 38 


\section{LIST OF TABLES (continued)}

Cb-2. Projected average fuel price escalation rates (excluding general price inflation), by end-use sector and fuel type. Census Region 2 (Illinois, Indiana, Iowa, Kansas, Michigan, Minnesota, Missouri, Nebraska, North Dakota, Ohio, South Dakota, Wisconsin) . . . . . . . . 39

$\mathrm{Cb}-3$. Projected average fuel price escalation rates (excluding general price inflation), by end-use sector and fuel type. Census Region 3 (Alabama, Arkansas, Delaware, District of Columbia, Florida, Georgia, Kentucky, Louisiana, Maryland, Mississippi, North Carolina, Oklahoma, South Carolina, Tennessee, Texas, Virginia, West Virginia) .............. 40

$\mathrm{Cb}-4$. Projected average fuel price escalation rates (excluding general price inflation), by end-use sector and fuel type. Census Region 4 (Alaska, Arizona, California, Colorado, Hawaii, Idaho, Montana, Nevada, New Mexico, Oregon, Utah, Washington, Wyoming) . . . 41

Cb-5. Projected average fuel price escalation rates (excluding general price inflation), by end-use

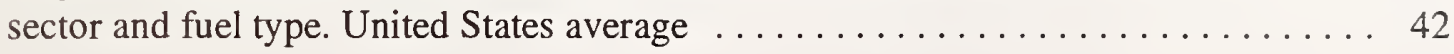

D. Factors for updating appliance label values from 1987 to 1996 dollars . . . . . . . 43

S-1. Projected fuel price indices with assumed general price inflation rates of 3, 4, 5, and 6 percent, by end-use sector and fuel type. Census Region 1 (Connecticut, Maine, Massachusetts, New Hampshire, New Jersey, New York, Pennsylvania, Rhode Island,

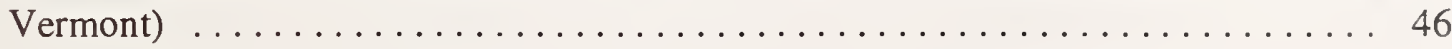

S-2. Projected fuel price indices with assumed general price inflation rates of 3, 4, 5, and 6 percent, by end-use sector and fuel type. Census Region 2 (Illinois, Indiana, Iowa, Kansas, Michigan, Minnesota, Nebraska, North Dakota, Ohio, South Dakota, Wisconsin) . . . 48

S-3. Projected fuel price indices with assumed general price inflation rates of 3, 4, 5, and 6 percent, by end-use sector and fuel type. Census Region 3 (Alabama, Arkansas, Delaware, District of Columbia, Florida, Georgia, Kentucky, Louisiana, Maryland, Mississippi, North Carolina, Oklahoma, South Carolina, Tennessee, Texas, Virginia, West Virginia) . . . 50

S-4. $\quad$ Projected fuel price indices with assumed general price inflation rates of 3, 4, 5, and 6 percent, by end-use sector and fuel type. Census Region 4 (Alaska, Arizona, California, Colorado, Hawaii, Idaho, Montana, Nevada, New Mexico, Oregon, Utah, Washington.

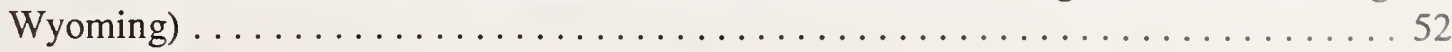

S-5. Projected fuel price indices with assumed general price inflation rates of 3,4 , 5, and 6 percent, by end-use sector and fuel type. United States average ........... 54 


\section{ABBREVIATIONS}

$\begin{array}{lll}\text { A } & - & \text { Annual amount } \\ \text { A }_{0} & - & \text { Annual amount at base-date prices } \\ \text { AEO97 } & - & \text { Annual Energy Outlook 1997 (DOE-EIA publication) } \\ \text { ASTM } & - & \text { American Society for Testing and Materials } \\ \text { BLCC } & - & \text { NIST Building Life Cycle Cost computer program } \\ \text { COAL } & - & \text { Coal } \\ \text { d } & - & \text { discount rate } \\ \text { DIST } & - & \text { Distillate Oil } \\ \text { DOE } & - & \text { U.S. Department of Energy } \\ \text { e } & - & \text { price escalation rate (annual rate of price change) } \\ \text { EIA } & & \text { Energy Information Administration (DOE) } \\ \text { ELEC } & - & \text { Electricity } \\ \text { FEMP } & - & \text { Federal Energy Management Program } \\ \text { FY } & - & \text { Fiscal Year } \\ \text { GASLN } & - & \text { Gasoline } \\ \text { LCC } & - & \text { Life-Cycle Cost } \\ \text { LPG } & - & \text { Liquefied petroleum gas } \\ \text { N } & - & \text { Number of discount periods (in years) } \\ \text { NEMS } & - & \text { National Energy Modeling System } \\ \text { NIST } & - & \text { National Institute of Standards and Technology } \\ \text { NTGAS } & - & \text { Natural Gas } \\ \text { OMB } & - & \text { Office of Management and Budget } \\ \text { RESID } & - & \text { Residual Oil } \\ \text { SPV } & - & \text { Single Present Value (factor) } \\ \text { UPV } & - & \text { Uniform Present Value (factor) } \\ \text { UPV } & - & \text { Modified Uniform Present Value (factor) }\end{array}$




\section{INTRODUCTION}

This report provides tables of present-value factors for use in the life-cycle cost analysis of capital investment projects for federal facilities. It also provides energy price indices based on Department of Energy (DOE) forecasts from 1997 to 2027. The factors and indices presented in this report are useful for determining the present value of future project-related costs, especially those related to operational energy costs. Discount factors included in this report are based on two different federal sources: (1) the DOE discount rate for projects related to energy conservation, renewable energy resources, and water conservation; and (2) Office of Management and Budget (OMB) discount rates from Circular A-94 for use with most other capital investment projects in federal facilities.

The DOE discount rate for 1997 is $3.8 \%$ real (i.e., net of general price inflation) or $6.9 \%$ nominal (including inflation). The DOE discount rate is based on long-term Treasury bond rates averaged over the 12 months prior to the preparation of this report. The nominal, or market rate, is converted to a real rate using the projected rate of general price inflation (2.9\%) from the Economic Report of the President's Council of Economic Advisors, to correspond with the constant-dollar analysis approach that is used in most federal life-cycle cost (LCC) analyses. Federal agencies and contractors to federal agencies are required by 10 CFR 436 to use the DOE discount rate when conducting LCC analyses related to energy conservation, renewable energy resources, and water conservation projects for federal facilities.

OMB Circular A-94 on guidelines and discount rates for benefit-cost analysis of federal programs was extensively revised in October 1992. There is no longer a single OMB discount rate as in the past. OMB has specified two basic types of discount rates: (1) a discount rate for cost-effectiveness, lease-purchase, and related analyses; and (2) a discount rate for public investment and regulatory analyses. Only discount rates for the first type of analyses are included in this Annual Supplement, since the primary purpose of this report is to support cost-effectiveness studies related to the design and operation of federal facilities.

OMB discount rates for cost-effectiveness and lease-purchase studies are based on interest rates on Treasury Notes and Bonds with maturities ranging from 3 to 30 years. Currently (as of January 1997) five maturities have been specifically identified by OMB, and are shown here with the corresponding real interest rate to be used as the discount rate for studies subject to OMB Circular A-94:

\begin{tabular}{|c|c|c|c|c|c|}
\hline Maturity: & 3-year & 5-year & 7-year & 10 -year & 30-year \\
\hline Rate: & $3.2 \%$ & $3.3 \%$ & $3.4 \%$ & $3.5 \%$ & $3.6 \%$ \\
\hline
\end{tabular}

OMB suggests that the actual discount rate for an economic analysis be interpolated from these maturities and rates, based on the study period used in the analysis. Due to limitations on the size of this Annual Supplement, discount factors for only two of these maturities are presented: factors for short-term analyses (up to 10 years) based on the 7-year real rate (3.4\%), and factors for long-term analyses (longer than 10 years) based on the 30 -year real rate (3.6\%). As a result, these discount factors are for approximation purposes only. It is suggested that the NIST Building Life Cycle Cost (BLCC) or DISCOUNT programs be used to compute the present value factors for the discount rate corresponding to the length of the study period when approximate values are not satisfactory for the project analysis. (See preface for details on obtaining these programs.)

The energy price indices and corresponding present value factors published in this report are computed from energy price forecasts provided to NIST by the Department of Energy's Energy Information 
Administration (EIA). The EIA energy price forecast used in this report was the most recent available at the time that this report was prepared. A description of the methodology used by EIA to project energy prices through 2027 is included in section B of this report. DOE has not projected escalation rates for water prices to be used in the LCC analysis of water conservation projects. Water escalation rates should be obtained from the local water utility when possible.

Federal agencies and contractors to federal agencies are encouraged to seek energy price projections from their local utility to use in place of the DOE/EIA regional projections, especially when evaluating alternative fuel types. In such cases the NIST BLCC or DISCOUNT programs can be used to calculate appropriate "modified uniform present value" (UPV*) factors for use in the LCC analysis of federal energy conservation or renewable resource projects. Otherwise, 10 CFR 436 requires the use of the DOE energy price forecasts when conducting LCC analyses of such projects. The UPV* factors for energy costs presented in this report have been precalculated with the DOE forecast data. Thus the use of these UPV* factors automatically ensures that the DOE forecast data have been included in the analysis.

All of the tables of discount factors contained in this report are based on real discount rates and are therefore intended for use only with economic analyses conducted in constant dollars (in which the purchasing power of the dollar is held constant). The energy price escalation rates and corresponding energy price indices contained in this report are also expressed in real terms. If nominal discount rates and current dollar costs (which both include inflation) are used in the LCC analyses of federal projects, use the BLCC computer program in the "general analysis" mode.

This report uses the term "present value" instead of "present worth" for the discount factors presented. The meaning of these two terms is considered to be identical for purposes of economic analysis. This change in terminology was made to be consistent with the terms used in the American Society for Testing and Materials (ASTM) compilation of standards on building economics (ASTM Standards on Building Economics, Third Edition, ASTM, Philadelphia, PA, 1994.)

In all of the tables, the "end-of-year" discounting convention is used, that is, all factors and indices are computed to adjust future dollar amounts to present value from the end of the year in which they are expected to occur. Because the publication date of this supplement is April 1, 1997, the year begins April 1 and ends March 31. "End-of-year" discounting therefore means that the factors are computed to discount to present value dollar amounts incurred one year from April 1. 


\section{PART I: TABLES FOR FEDERAL LIFE-CYCLE COST ANALYSIS}

\section{A. Single Present Value and Uniform Present Value Factors for Non-Fuel Costs}

Table A-1 presents the single present value (SPV) factors for finding the present value of future non-fuel, non-annually recurring costs, such as repair and replacement costs and salvage values. The formula for finding the present value $(P)$ of a future cost occurring in year $t\left(C_{v}\right)$ is the following:

$$
P=C_{t} x \frac{1}{(1+d)^{t}}=C_{t} \times S P V_{t},
$$

where $\mathrm{d}=$ discount rate, and

$\mathrm{t}=$ number of time periods (years) between the present time and the time the cost is incurred.

Table A-2 presents uniform present value (UPV) factors for finding the present value of future non-fuel costs recurring annually, such as routine maintenance costs. The formula for finding the present value $(\mathrm{P})$ of an annually recurring uniform cost (A) is the following:

$$
P=A \times \frac{(1+d)^{N}-1}{d(1+d)^{N}}=A x U P V_{N}
$$

where $\mathrm{d}=$ discount rate, and

$\mathrm{N}=$ number of time periods (years) over which A recurs.

Tables $A-3(a, b, c)$ present modified uniform present value (UPV*) factors for finding the present value of annually recurring non-fuel costs, such as water costs, which are expected to change from year to year at a constant rate of change (or escalation rate) over the study period. The escalation rate can be positive or negative. The formula for finding the present value $(\mathrm{P})$ of an annually recurring cost at base-date prices $\left(A_{0}\right)$ changing at escalation rate $\mathrm{e}$ is the following:

$$
P=A_{0} x\left(\frac{1+e}{d-e}\right)\left[1-\left(\frac{1+e}{1+d}\right)^{N}\right]=A_{0} x U P V_{N}^{*} \quad(d \neq e)
$$

or

$$
P=A_{0} \times N=A_{0} \times U P V^{*} \quad(d=e),
$$

where $\mathrm{A}_{0}=$ annually recurring cost at base-date prices,

$\mathrm{d}=$ discount rate,

e $=$ escalation rate, and

$\mathrm{N}$ = number of time periods (years) over which $\mathrm{A}$ recurs.

Note: if the discount rate is expressed in real terms, i.e., net of general inflation, then the escalation rate must also be expressed in real terms. If the discount rate is expressed in nominal terms, i.c., including general inflation, then the escalation rate must also be expressed in nominal terms. 
In tables A-1, A-2, and A-3(a,b,c) SPV, UPV, and UPV* factors are provided for both the DOE and the OMB Circular A-94 real discount rates current as of the date of this publication. The FEMP SPV, UPV, and UPV* factors were computed using the DOE discount rate. The FEMP factors are for finding the present value of future costs associated with federal energy and water conservation projects and renewable energy projects. The OMB SPV, UPV, and UPV* factors were computed using the OMB discount rate. The OMB factors are for finding the present value of future costs associated with most other federal projects (except those specifically exempted from OMB Circular A-94). The DOE and OMB discount rates used in computing these tables are real rates, exclusive of general price inflation. Thus the resulting discount factors are intended for use with future costs that are stated in constant dollars.

\section{Examples of How to Use the Factors:}

SPV (FEMP): To compute the present value of a replacement cost expected to occur in the 8th year for an energy efficient heating system, go to Table A-1, find the 3.8\% SPV factor for year $8(0.742)$, and multiply the factor by the replacement cost as of the base date.

SPV (OMB, Short-term): To compute the present value of a repair cost in the 5th year for a floor covering (non-energy related), go to Table A-1, find the $3.4 \%$ SPV factor for year $5(0.846)$, and multiply the factor by the repair cost as of the base date.

SPV (OMB, Long-term): To compute the present value of a repair cost in the 15 th year for a floor covering (non-energy related), go to Table A-1, find the $3.6 \%$ SPV factor for year 15 (0.588), and multiply the factor by the repair cost as of the base date.

UPV (FEMP): To compute the present value of an annually recurring maintenance cost for a renewable energy system over 20 years, go to Table A-2, find the $3.8 \%$ UPV factor for 20 years (13.83), and multiply the factor by the annual maintenance cost as of the base date.

UPV (OMB, Short-term): To compute the present value of annually recurring costs of office cleaning over 10 years (for a project not primarily related to energy conservation), go to Table A-2, find the $3.4 \%$ UPV factor for 10 years (8.36), and multiply the factor by the annual cleaning cost as of the base date.

UPV (OMB, Long-term): To compute the present value of annually recurring costs of office cleaning over 25 years (for a project not primarily related to energy conservation), got to Table A-2, find the $3.6 \%$ UPV factor for 25 years (16.30), and multiply the factor by the annual cleaning cost as of the base date.

UPV* (all): To compute the present value of annually recurring costs of water usage which are expected to increase at $2 \%$ faster than the rate of general inflation over 25 years, find the UPV* factor from table A-3 (a,b, or c as appropriate) that corresponds to $2 \%$ escalation and a 25 year study period. From table A-3a (3.8\% DOE discount rate) the corresponding UPV* factor is 20.07 . Multiply this factor by the annual water cost as computed at base year prices to determine the present value of these water costs over the entire 25 years.

NOTE: UPV factors are generally applied to costs that recur annually in substantially the same amount. Examples of such costs are routine operating and maintenance costs. UPV* factors are generally applied to costs that recur annually but change from year to year at a constant escalation rate. Examples of such costs are water usage costs when they increase from year to year. These costs usually occur every year 
over the service period of the building life. If there is a planning/design/ construction period before the service life begins, during which these annual costs are not incurred, the appropriate UPV (or UPV*) factor for the service period is the difference between the UPV (or UPV*) factor for the entire study period and the UPV (or UPV*) factor for the planning/design/ construction period. For example, if the planning/design/ construction period is 3 years and the service period is 25 years, for a total study period of 28 years, the corresponding UPV factor (from Table A-2, DOE $3.8 \%$ discount rate) is $17.05-2.79=$ 14.26 .

For further explanation and illustration of how to use these factors, see NIST Handbook 135. 
Table A-1. SPV factors for finding the present value of future single costs (non-fuel)

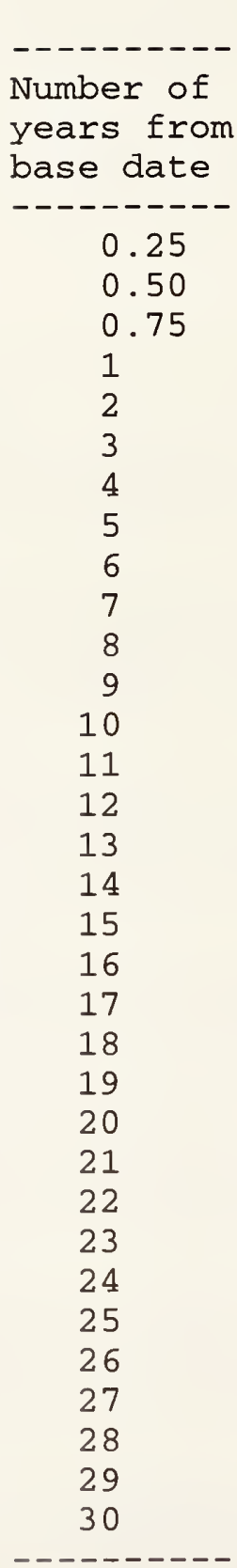

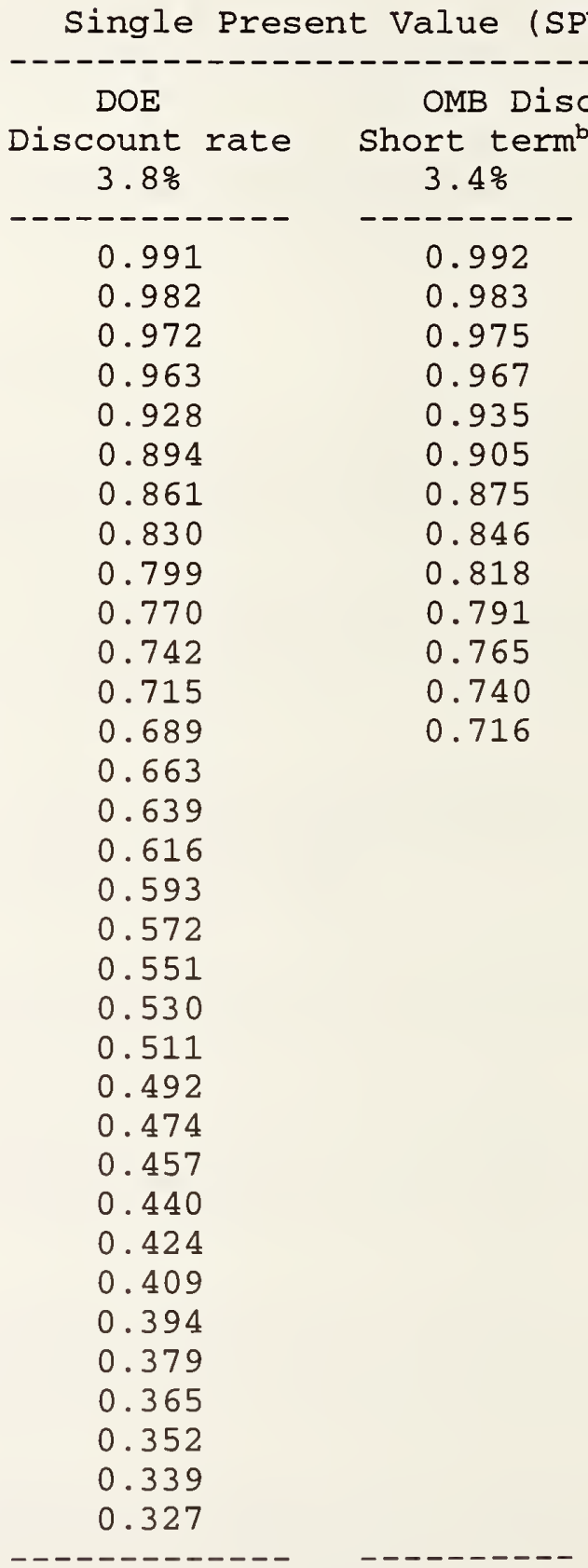

0.991

0.982

0.974

0.965

0.932

0.899

0.868

0.838

0.809

0.781

0.754

0.727

0.702

0.678

0.654

0.631

0.609

0.588

0.568

0.548

0.529

0.511

0.493

0.476

0.459

0.443

0.428

0.413

0.399

0.385

0.371

0.359

0.346

${ }^{\text {a }}$ OMB discount rates as of February 1997.

${ }^{\text {b }}$ Short-term discount rate based on OMB discount rate for 7-year study period. ${ }^{c}$ Long-term discount rate based on OMB discount rate for 30-year study period. 
Table A-2. UPV factors for finding the present value of annually recurring uniform costs (non-fuel)

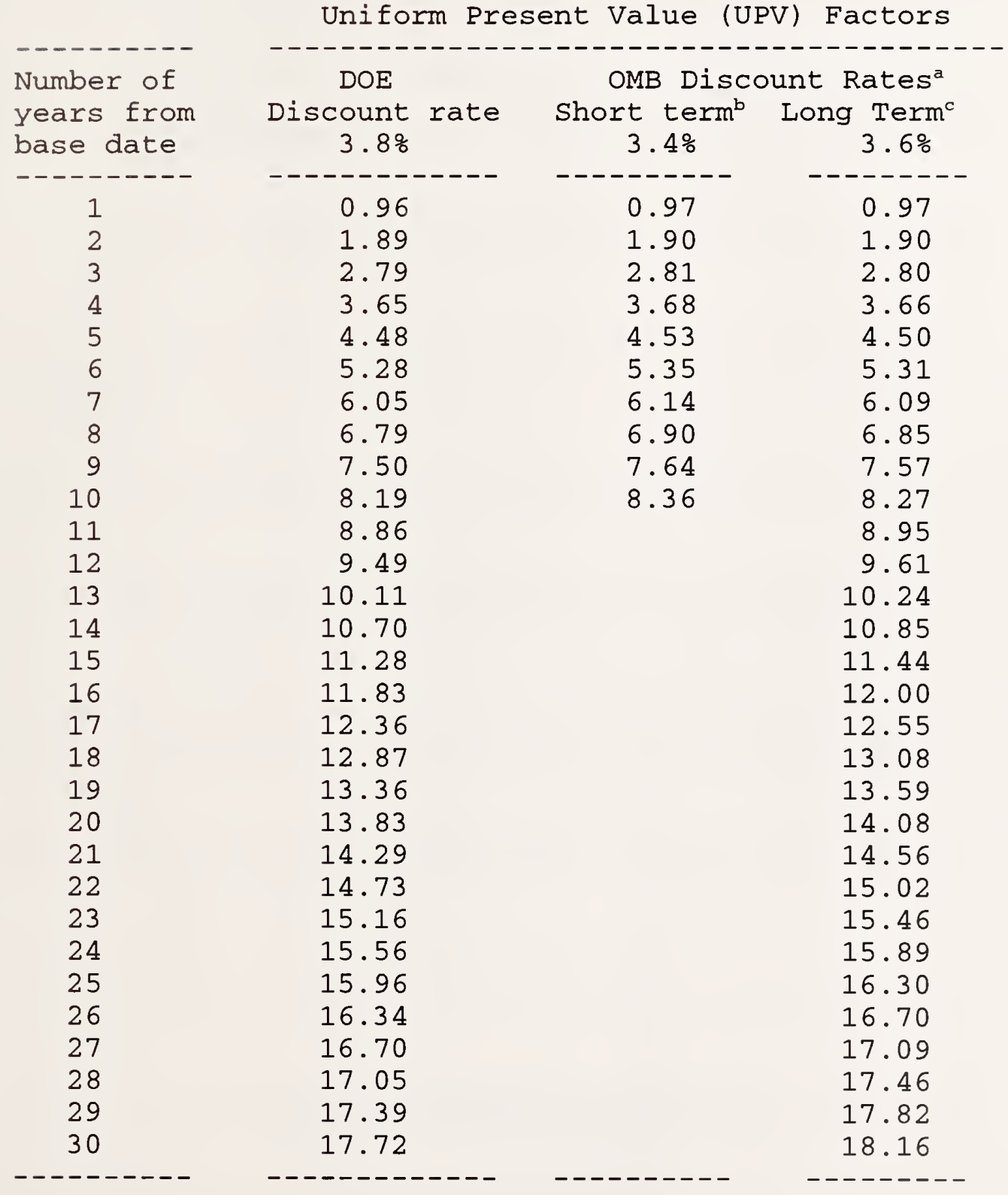

${ }^{\mathrm{a} O M B}$ discount rates as of February 1997.

bShort-term discount rate based on OMB discount rate for 7-year study period.

${ }^{\mathrm{c}}$ Long-term discount rate based on OMB discount rate for 30 -year study period. 


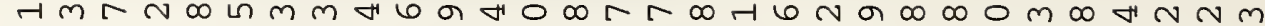
व $10004 \pi N m$ स HNm

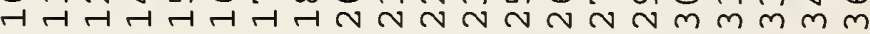

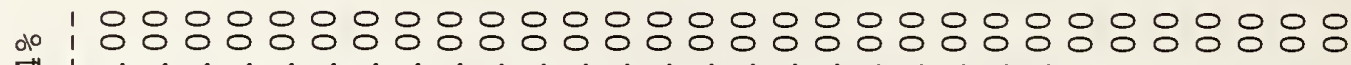
न

a $\infty$ แn ब म

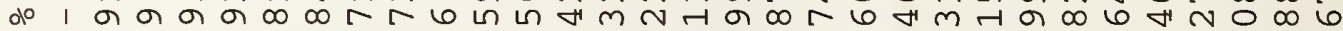
m l. $\cdot 0.0 .0 .0 .0$.

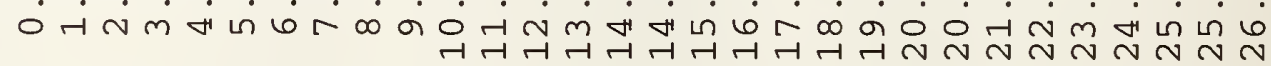

I $\infty$ L do a ब व

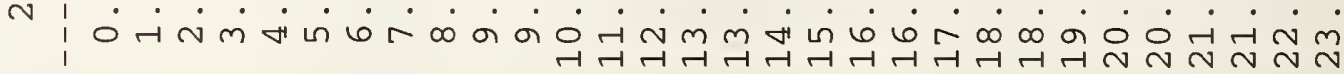

$15 \pi$ h h do क न 1 \%

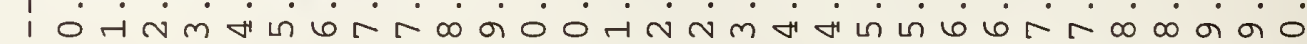

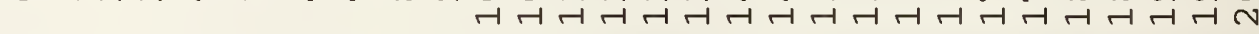

।

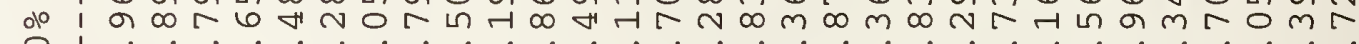

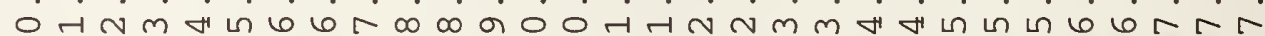

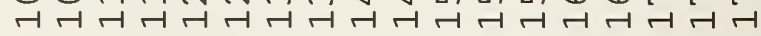

ग I न (1) 1 , ।

1 H

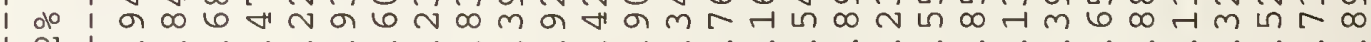

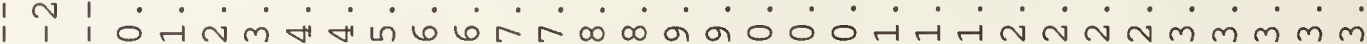
1 i

I m H

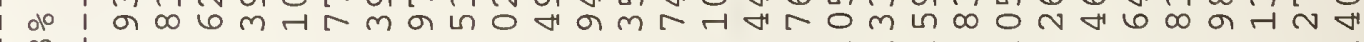
1,0 HNm

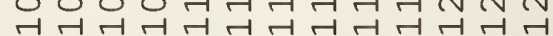

I N $\infty$ r 0 - $\infty$ N H do aर ।

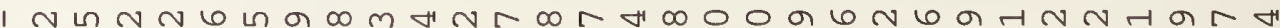

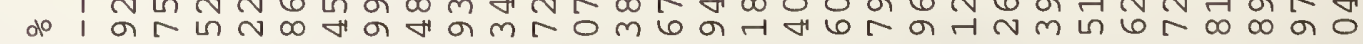

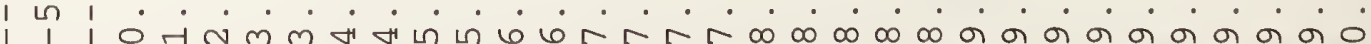
1

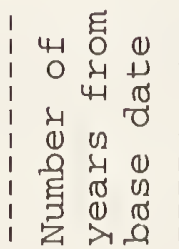

HNm

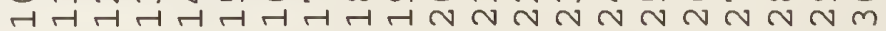




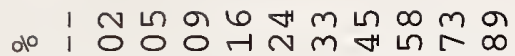
n 1.0 .0$.

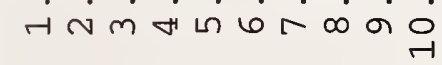

1 4 $2 m \in$ a ग $1000004 \pi N C M$ i

I 0 a $\infty$ H

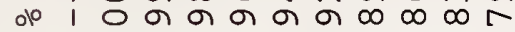

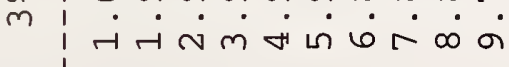
I ग । न ब $\infty$ ก

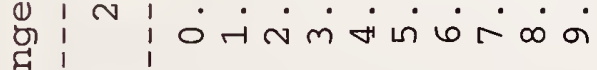
$1 \infty m \omega R \omega m \infty$ H म \begin{tabular}{l|l}
0 & $0 \pi N m$ मा \\
-4 & 0
\end{tabular} प्र

थ 1 I 1 -

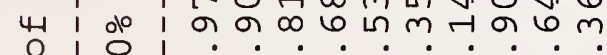
(1)

$\begin{array}{ll}0 & 1\end{array}$ 4
I

I 6 N

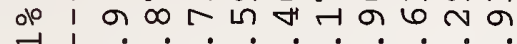

1 0 तं

3

厽 I L ol वका

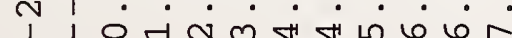
I

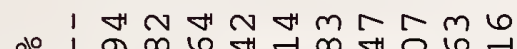

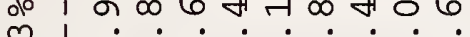
$1: 04 N m$ H

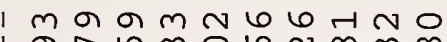
ग

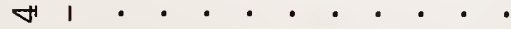
1 1 0 H $m$ सं

2 2 स 4 H ग ब बा ए

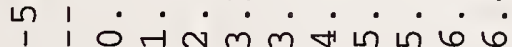
I

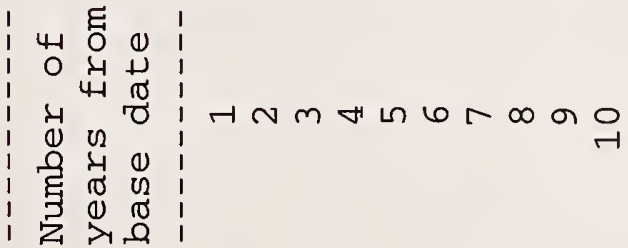

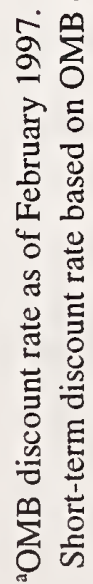


, न म

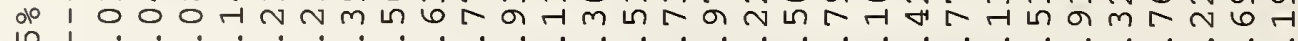
i H H

10 I 0 म

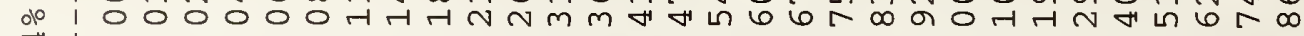

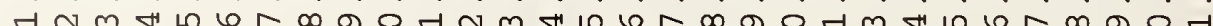
HनH

ब $\infty \hat{\sigma}$ न

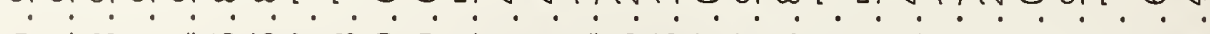

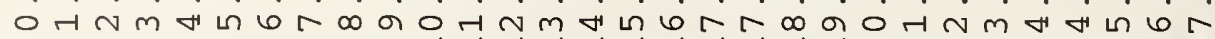

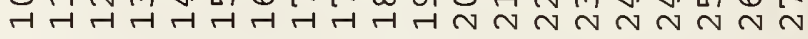

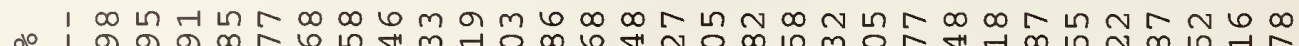

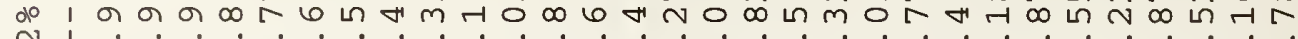

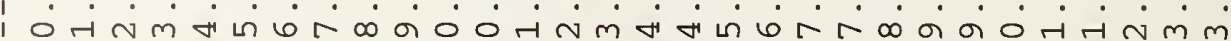
म न म न म न म

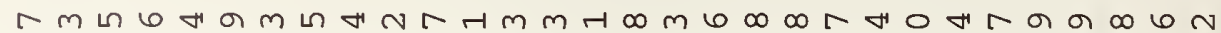

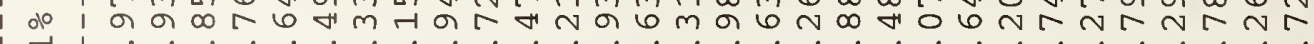

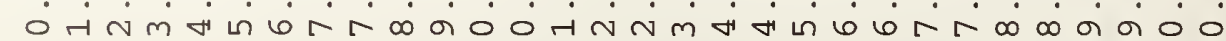

No 060 H

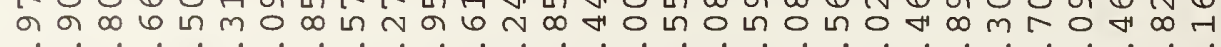

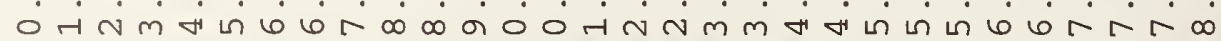
1

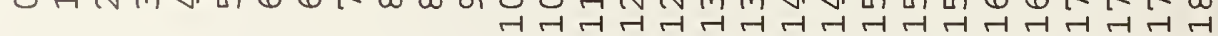
ग ।

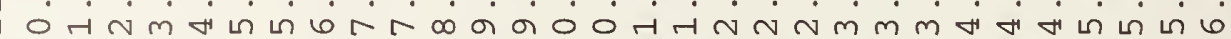

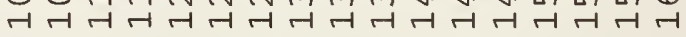

म

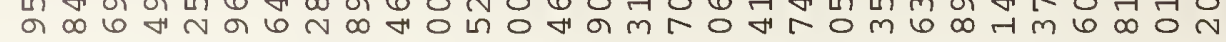
do I 10 ,

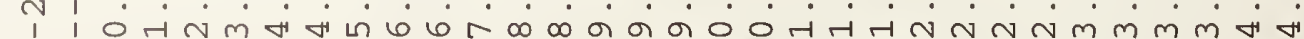
न $\mathrm{Am}$ म

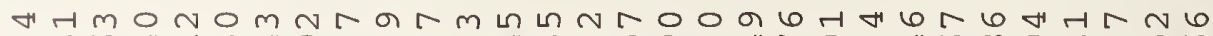

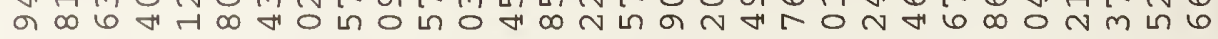
O तम

ma

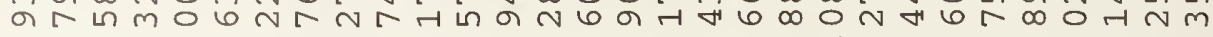
OH

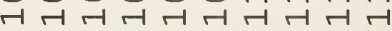

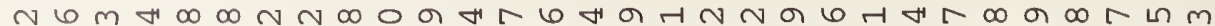
ग आR 1 1 1 HNmm

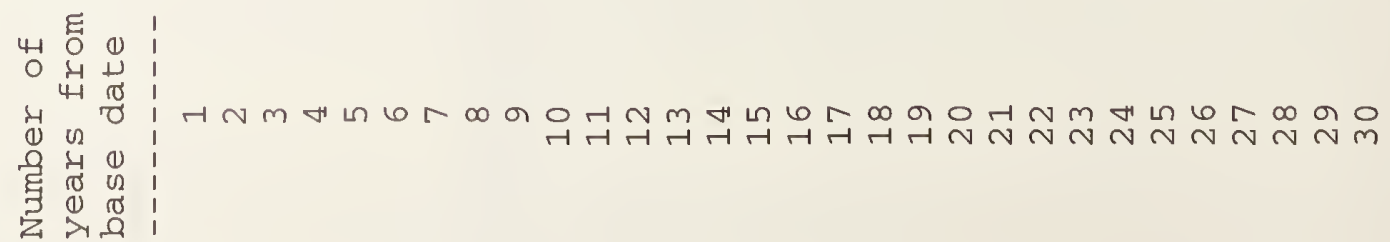




\section{B. Modified Uniform Present Value Factors for Fuel Costs}

This section presents FEMP and OMB modified uniform present value $\left(\mathrm{UPV}^{*}\right)$ discount factors for calculating the present value of energy usage for federal projects. Factors are provided for the four major Census regions and for the overall United States. The factors are modified in the sense that they incorporate energy price escalation rates based on future energy prices projected by DOE for the years 1997-2026. There are two sets of UPV* tables: the "Ba" tables present FEMP UPV* factors based on the DOE discount rate $(3.8 \%$ real), and the "Bb" tables present OMB UPV factors based on two OMB discount rates (3.4\% real for short-term study periods of 1 to 10 years, $3.6 \%$ real for long-term study periods of 11 to 30 years). The underlying energy price indices for the years 1997 to 2026 on which these UPV* calculations are based are shown in tables Ca-1 through Ca-5. The corresponding average energy price escalation rates for selected time intervals between 1997 and 2026 are shown in tables Cb-1 through $\mathrm{Cb}-5$.

\section{Energy Price Projections}

The FEMP and OMB UPV* factors incorporate energy price escalation rates computed from future energy prices projected by the Energy Information Administration (EIA) of the U.S. Department of Energy. Energy prices through 2015 were generated by EIA using the National Energy Modeling System (NEMS) and published in the Annual Energy Outlook $1997^{1}$ (AEO97). At the request of FEMP, EIA extrapolated energy prices after the year 2015 from the AEO97 data.

NEMS is an energy market model designed to project the impacts of alternative energy policies or assumptions on U.S. energy markets. NEMS produces projections of the U.S. energy future, given current laws and policies and other key assumptions, including macroeconomic indicators from Data Resources, Inc., the production policy of the Organization of Petroleum Exporting Countries, the size of the economically recoverable resource base for fossil fuels, and the rate of development and penetration of new technologies. NEMS balances energy supply and demands with modules representing primary fuel supply, end-use demand for four sectors, and conversion of energy by refineries and electricity generators. Macroeconomic and international oil modules reflect the impacts of energy prices, production, and consumption on world oil markets and the economy.

In order to produce price projections to 2026, EIA extrapolated the prices from the $A E O 97$ with specific assumptions about long-term trends. To provide long-term price expectations to the post-2015 projections, world oil price expectations through 2050 were calculated using assumptions of world oil supply and demand. These expectations were used as the basis for the 2026 projections of petroleum product prices, using the implied 2015 refinery markups to calculate the regional, end-use prices.

The EIA energy price projections presented in this report, like those of other forecasters, are dependent on the data, methodologies, and specific assumptions used in their development. Many of the assumptions concerning the future cannot be known with any degree of certainty. Thus, the projections are not statements of what will happen, but what might happen given the particular assumptions and methodologies used. Although EIA has endeavored to make these forecasts as objective, reliable, and

\footnotetext{
${ }^{1}$ Energy Information Administration, Annual Energy Outlook 1997, DOE/EPA-0383(97), January 1997.
} 
useful as possible, these projections should serve as an adjunct to, not a substitute for, the analytical process. The AEO97 was prepared by EIA as required under statute by federal legislation. The price projections to 2026 were prepared in accordance with a Service Request from the Federal Energy Management Program.

\section{UPV* Calculation Method}

The formula for finding the present value $(\mathrm{P})$ of future energy costs or savings is the following:

$$
P=A_{o} \times \sum_{t=1}^{N} \frac{I_{(1997+t)}}{(1+d)^{t}}=A_{o} x U P V_{N}^{*},
$$

where $\mathrm{A}_{\mathrm{o}} \quad=$ annual cost of energy as of the base date;

$\mathrm{t} \quad=$ index used to designate each year, with $\mathrm{t}=1$ for the year 1997;

$\mathrm{N} \quad=$ number of periods, e.g., years, over which energy costs or savings accrue;

$\mathrm{I}_{(1997+\mathrm{t})}=$ projected average fuel price index ${ }^{2}$ given in Tables Ca-1 through Ca-5 for the year $1997+\mathrm{t}$ (where $\mathrm{I}_{1997}=1.00$ ); and

$\mathrm{d}=$ the discount rate.

This formula is based on end-of-year energy prices and end-of-year discounting. Note that annual energy costs as of the base date $\left(A_{0}\right.$, to be supplied by the analyst) should reflect the current energy price schedule as of the base date, which may not be the same as the energy price itself on that date. That is, the annual energy cost should reflect summer-winter rate differences, time-of-use rates, block rates considerations, and demand charges (as appropriate) anticipated to be in effect that year. If energy and demand costs are calculated separately (as is sometimes done for electricity), the UPV* factor should be applied to both costs.

The data in the tables that follow are reported for the four Census regions and the U.S. average. Figure B-1 presents a map showing the states corresponding to the four Census regions. The Census regions do not include American Samoa, Canal Zone, Guam, Puerto Rico, Trust Territory of the Pacific Islands, or the Virgin Islands. Analysts of federal projects in these areas should use data which are "reasonable under the circumstances," and may refer to the tables with U.S. average data for guidance.

\footnotetext{
${ }^{2}$ For greater precision, the UPV* factors reported in the $\mathrm{Ba}$ and $\mathrm{Bb}$ tables were computed using the unrounded form of the indices given in Tables Ca-1 through Ca-5.
} 


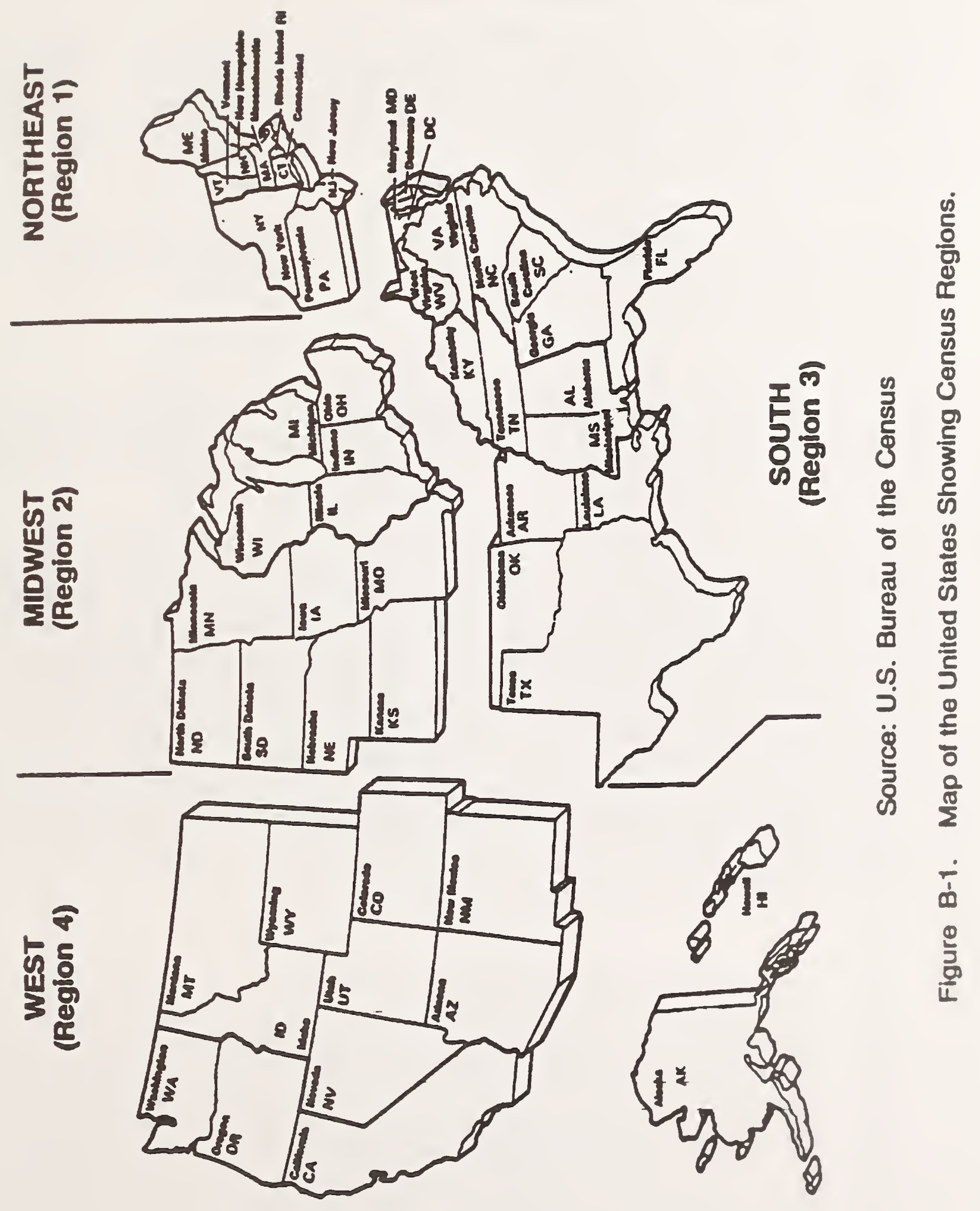




\section{B.1. FEMP Modified Uniform Present Value Factors}

The FEMP Modified Uniform Present Value (FEMP UPV*) factors presented in the "Ba" tables, based on the current DOE discount rate (3.8\%), are for calculating the present value of energy costs or savings accruing over 1 to 25 years and are to be used in life-cycle cost analyses of federal energy conservation and renewable energy projects. Factors are reported in the "Ba" tables for 30 years to accommodate a planning/design/construction period of up to 5 years. (See "Examples of How to Use FEMP UPV* Factors" below for instructions on use with planning/design/construction periods.)

These factors apply only to annual energy usage or energy savings that are assumed to be the same each year over the service period. The NIST BLCC computer program can compute the present value of energy usage and savings which are not the same in each year.

\section{Examples of How to Use the FEMP UPV* Factors:}

FEMP UPV*, no planning/design/construction period: To compute the present value of heating with natural gas over 25 years in a federal office building in New Mexico, go to Table Ba-4, find the FEMP UPV $^{*}$ factor for commercial natural gas for 25 years (15.17), and multiply this factor by the annual heating cost at base-date natural gas prices.

FEMP UPV*, with planning/design/construction period: To compute a present value factor for a service period following a planning/design/construction period (1) find the FEMP UPV* factor for the combined length of the planning/design/construction period and the service period (not to exceed 30 years), and (2) subtract from (1) the FEMP UPV* factor for the planning/design/construction period alone. The difference is the FEMP UPV* factor for the years over which energy costs or savings actually accrue. For example, suppose a new federal office building in New York is being evaluated with several energy conserving design options. It is expected to have a planning/design/ construction period of 5 years, after which it will be occupied for at least 25 years. To compute the present value of natural gas costs over 25 years of occupancy, go to Table Ba-1 and find the FEMP UPV factors for commercial natural gas for 5 years (4.45) and for 30 years (16.80). The difference (12.35) is the FEMP UPV factor for natural gas costs over 25 years, beginning 5 years after the base date. Multiply 12.35 by the annual natural gas cost at base-date prices (not occupancy-date prices) to calculate the present value of natural gas costs over the entire 25-year occupancy period. 


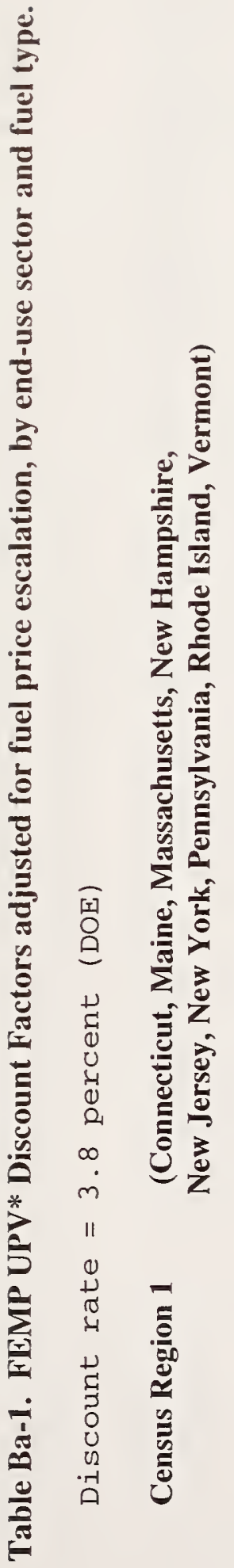

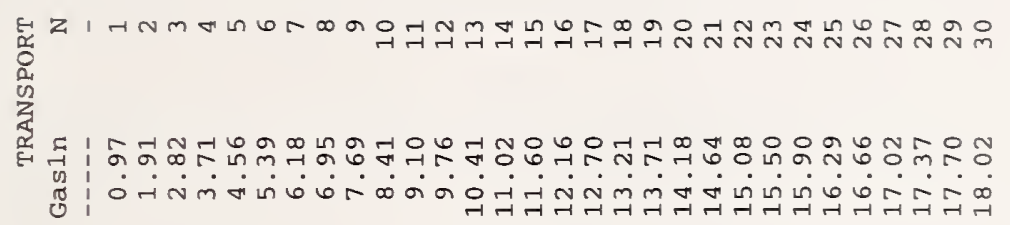

ન ठ

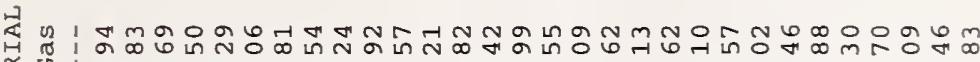
䒜 ,

诈 凹 ठ

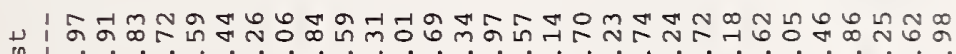
年

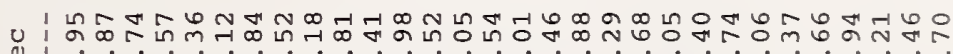
|

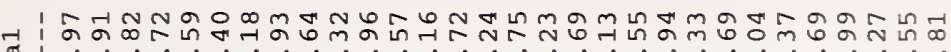
ठ

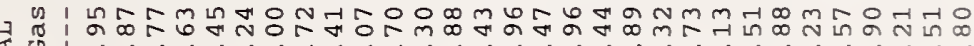
岁 亜

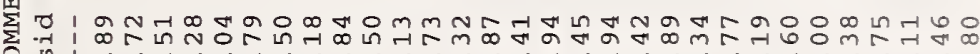
U

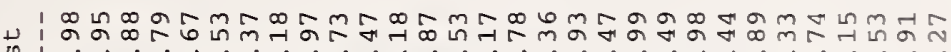
-

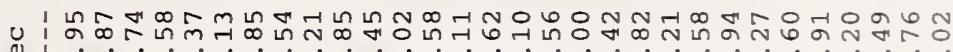

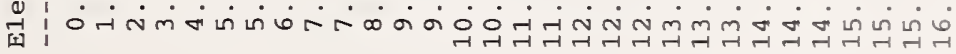

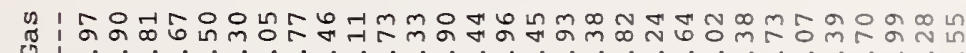
定艺 萑 密

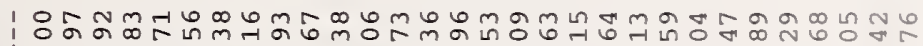
过 -

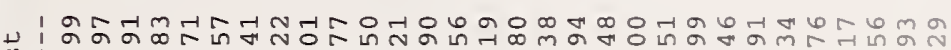
-

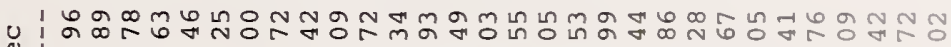
考

z 1 4nm 

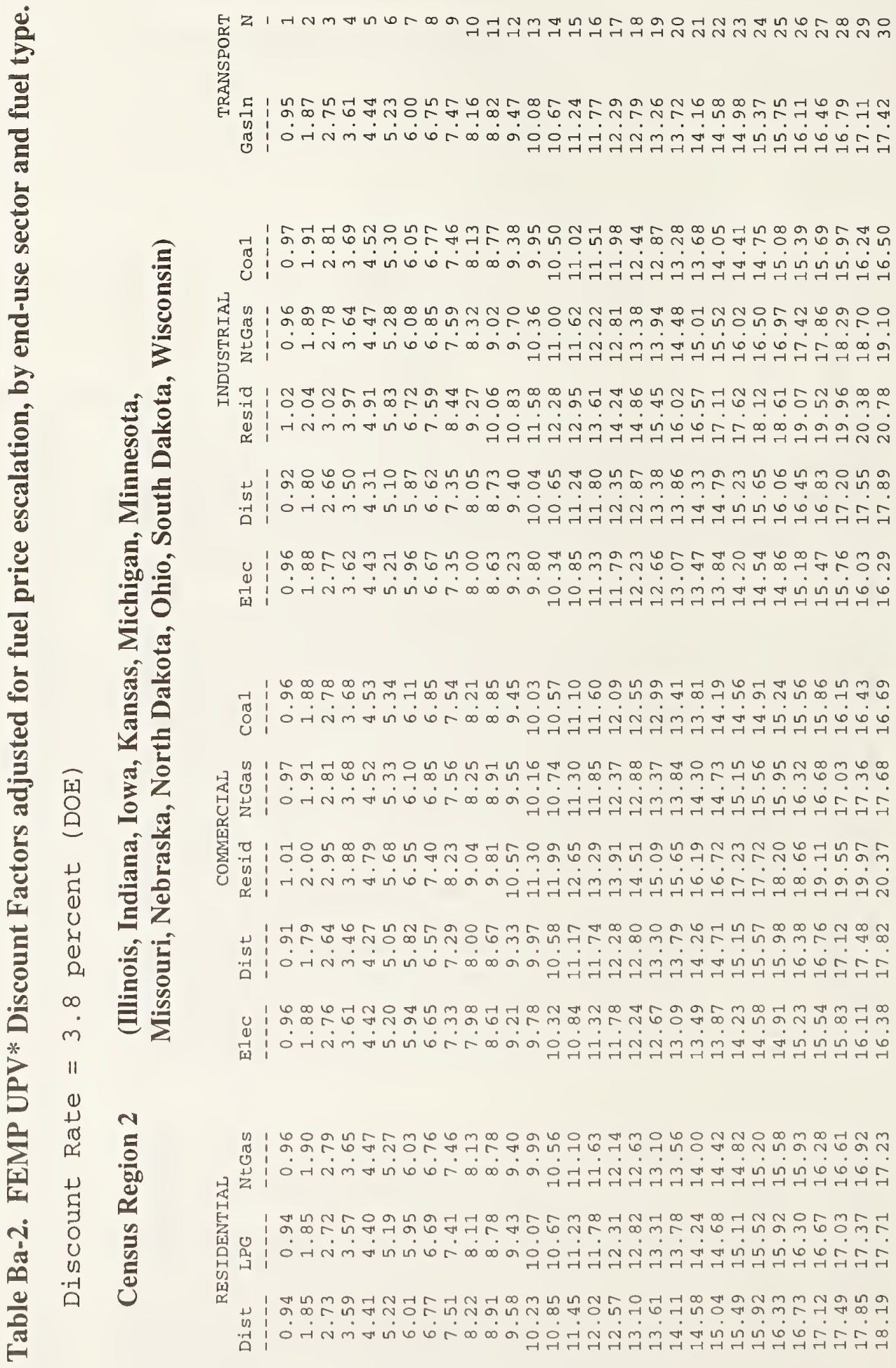

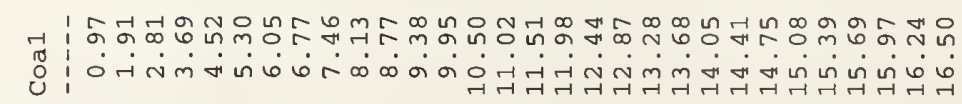
崫业: 留艺 它

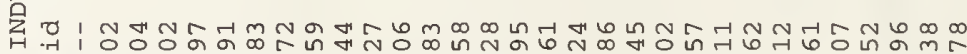

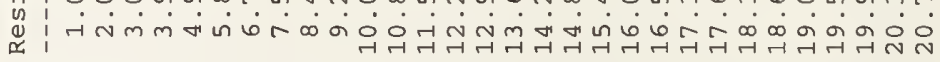

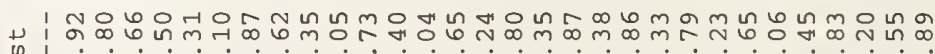
|- ठ

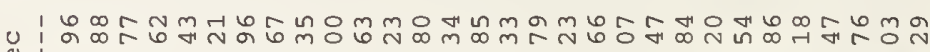
者

ન|

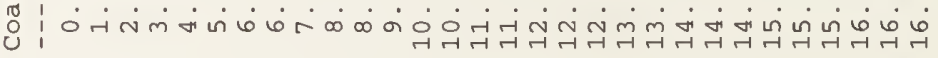

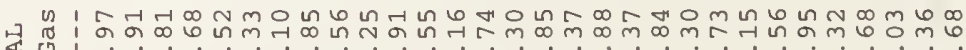

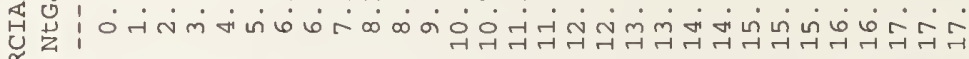
垔

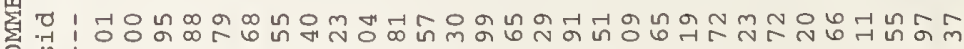

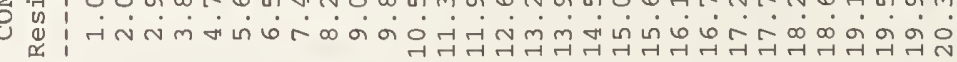

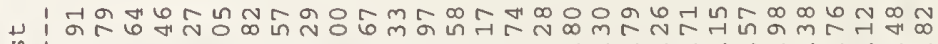
u

○| Кळ 严

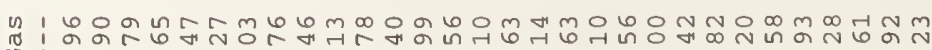
분 ग 昆 肴

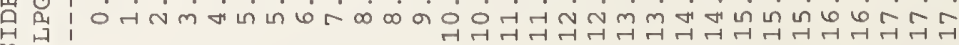
兒

•

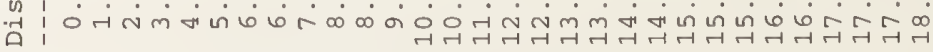

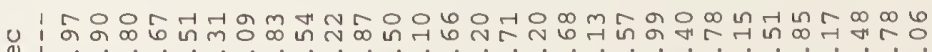

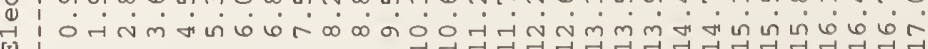
z 1 H 
及 1 म

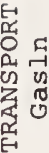

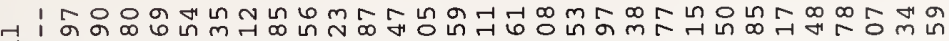

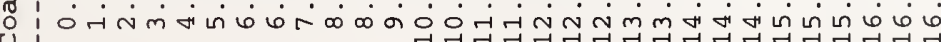
ש 党 .

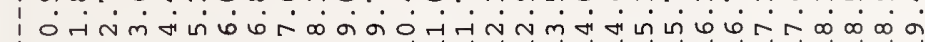

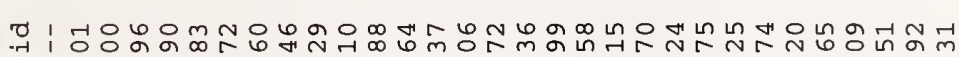

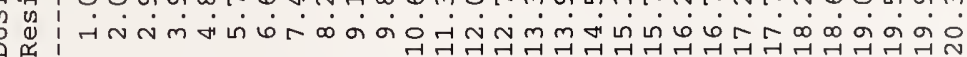

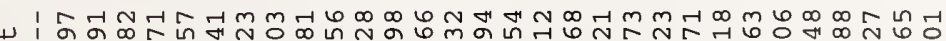

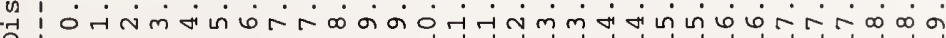
ט

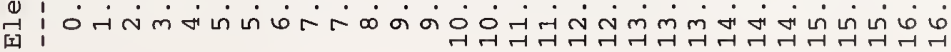

ᄀ| ठ ठ

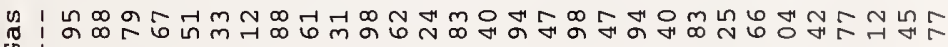

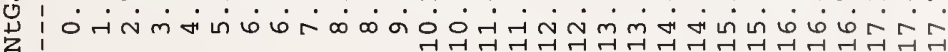

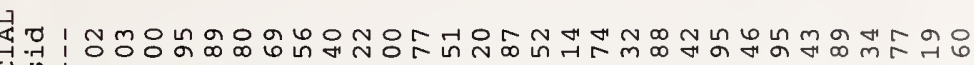

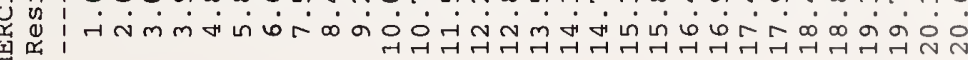

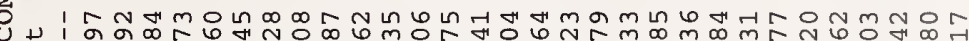

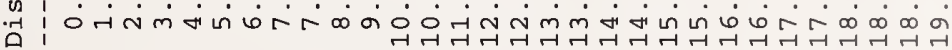
ن 青

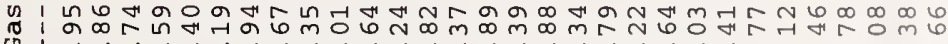

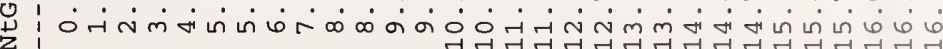

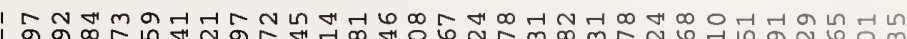

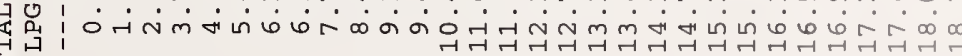

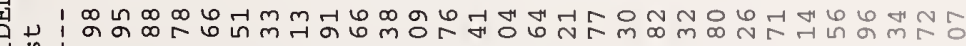
O

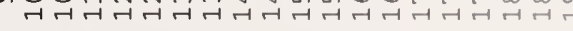

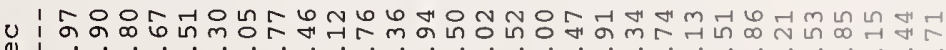

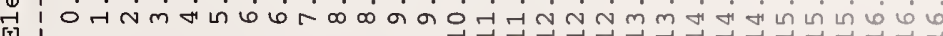

z I 
囟z

总

列 ठ̃

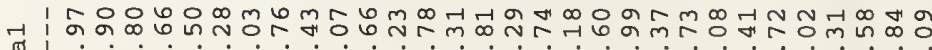
ठ̊ 宏 of 芴: व 党。

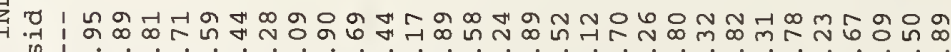
U)

|ำ U ठ

1

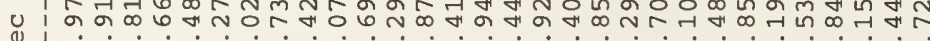

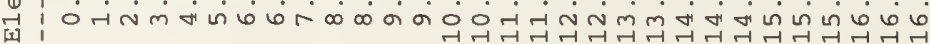

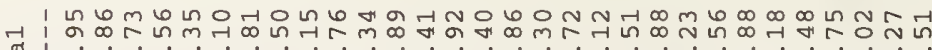
ठठ ठ

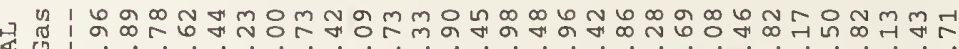

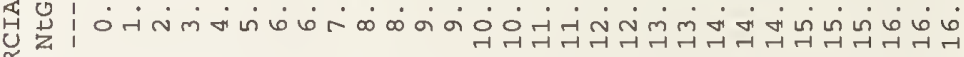
国

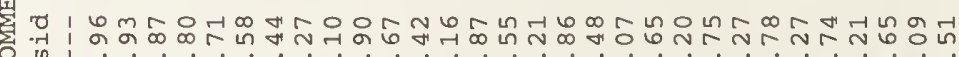

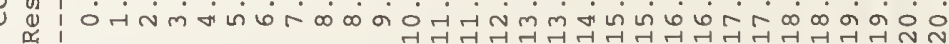
山| â

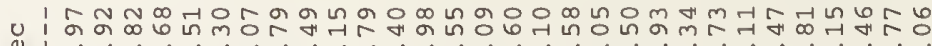

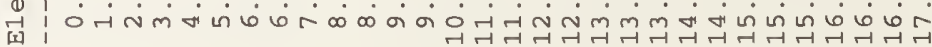

ป 落

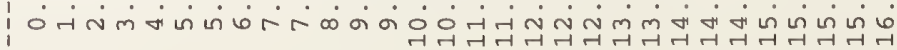

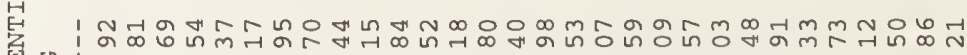

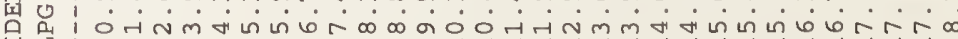
要 山

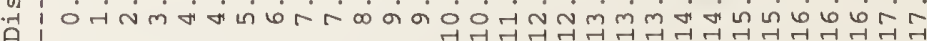

0|

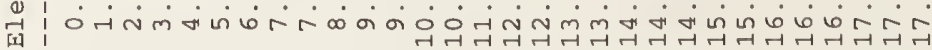




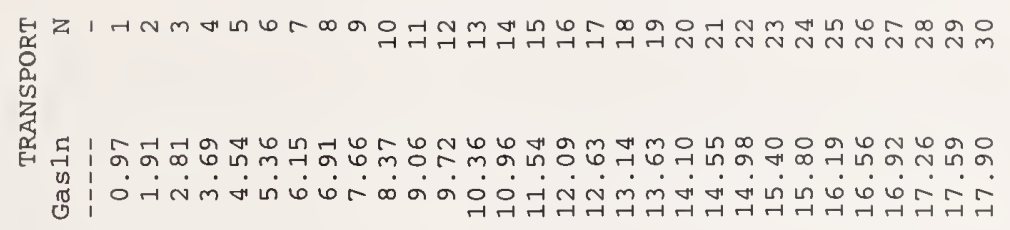

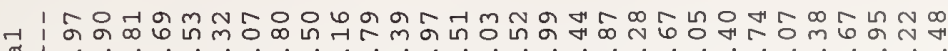

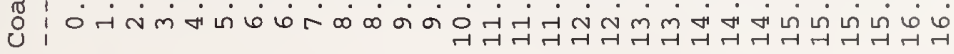

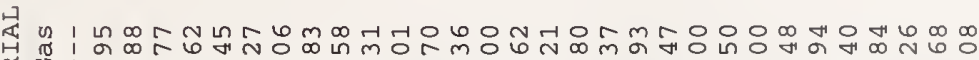
政 鼠| 员

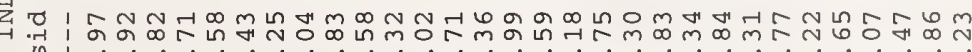
0 ठ

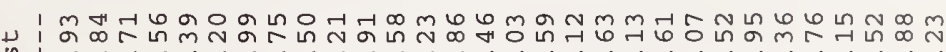

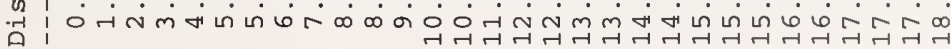

0| 至

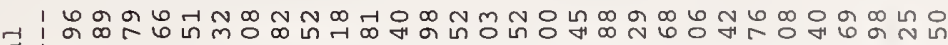

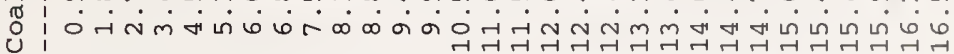

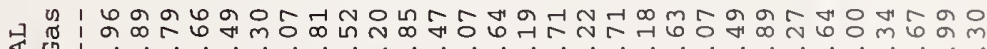
苟

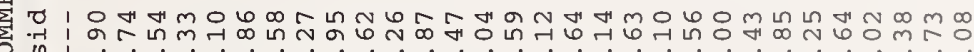

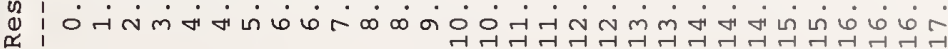

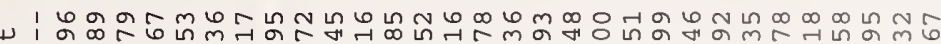

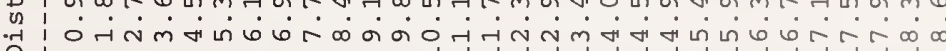

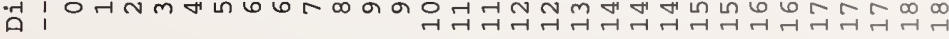

○ ด้ 4 O

彳 | 是艺

प ठ 昆

| व

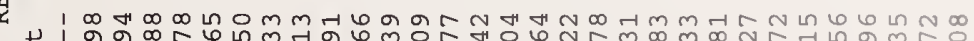
1 बढ मी

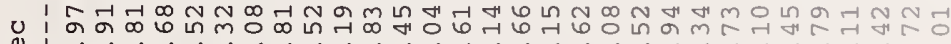
or z 1 H 


\section{B.2. OMB Modified Uniform Present Value Factors}

The OMB Modified Uniform Present Value (OMB UPV*) factors presented in the "Bb" tables, based on the current $\mathrm{OMB}$ discount rates (3.4\% short term and 3.6\% long term), are for calculating the present value of energy costs accruing over 1 to 30 years when conducting a life-cycle cost analysis of a federal project which is not explicitly related to energy or water conservation or renewable resources. Factors are reported in the "Bb" tables for 30 years. These factors apply only to annual energy usage that is assumed to be the same each year over the service period. The NIST BLCC computer program can compute the present value of energy usage and savings that are not the same in each year.

\section{Examples of How to Use the OMB UPV* Factors:}

OMB UPV* (OMB discount rate): To compute the present value over 30 years of electricity costs associated with the occupancy of a federal office building in Ohio (where energy conservation is not a specific consideration in the LCC analysis), go to Table Bb-2, find the OMB UPV* factor for commercial electricity for 30 years (16.77), and multiply this factor by the annual electricity cost in base-date dollars.

NOTE: Because the discount rate used to calculate the $\mathrm{Bb}$ tables (OMB discount rate) is different for years $1-10(3.4 \%)$ than for years $11-30(3.6 \%)$, these factors cannot be used with a planning/design/construction period as shown above for the Ba tables (DOE discount rate). Use the BLCC or DISCOUNT computer program for this purpose. For further explanation of the use of UPV* factors, see NIST Handbook 135. 


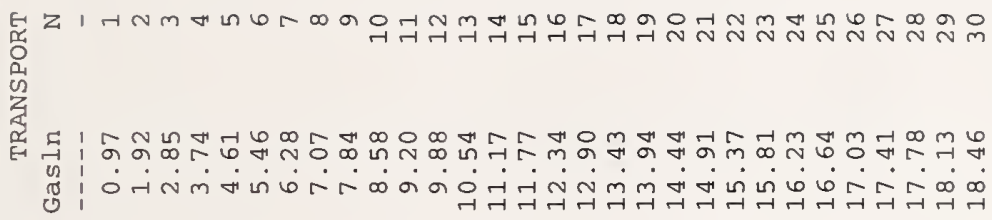

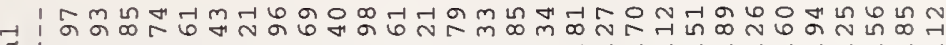
ठ ठ

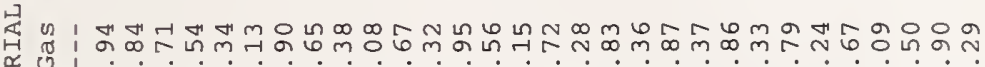

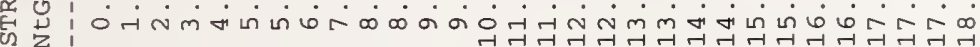
品 能。|

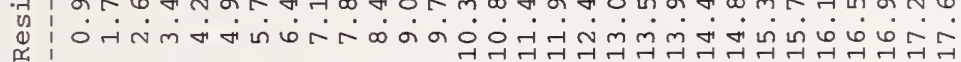

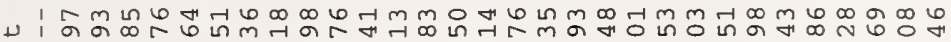

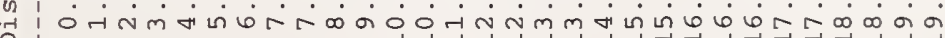

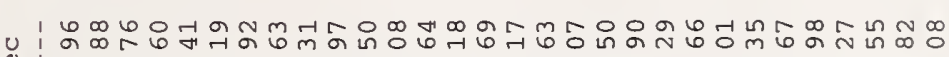
$\Rightarrow$ O

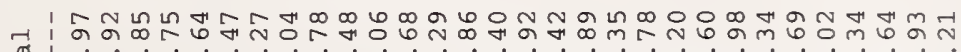

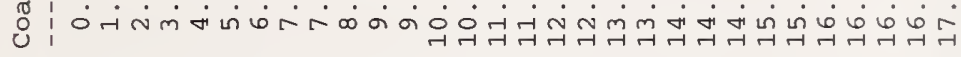

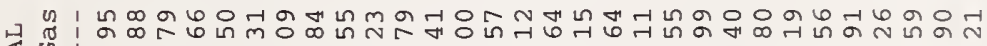

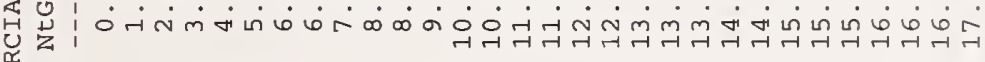

四 オ ठ ह ه ठ

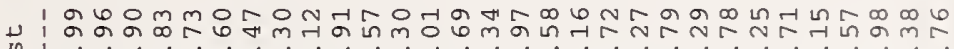

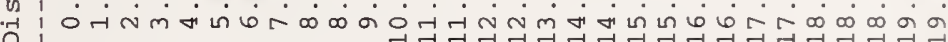

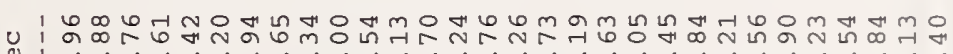

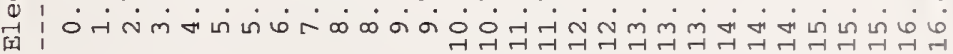

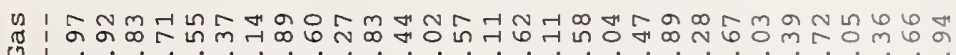
紊

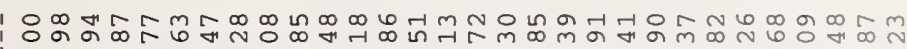
O 1

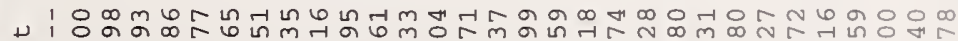

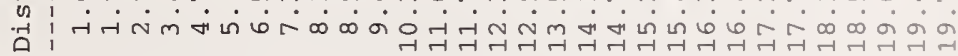
U

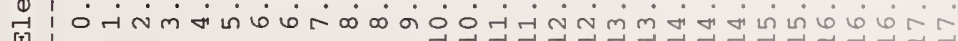

z 1 Hnm 
z I न

곡 गु

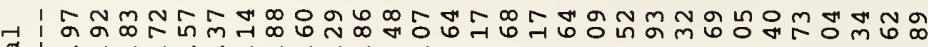
ठ 崫约

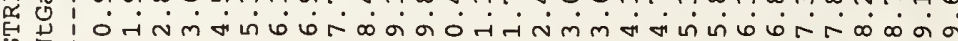
员

J

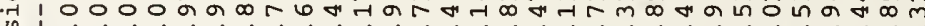
Q न

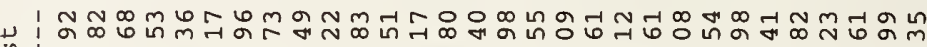
n म

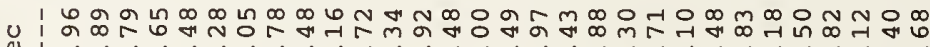
|r

거 ठ ठ

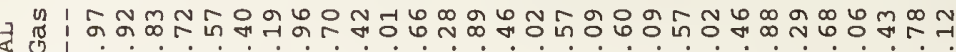

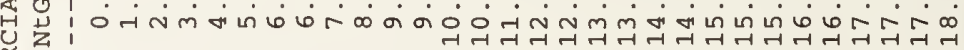
空

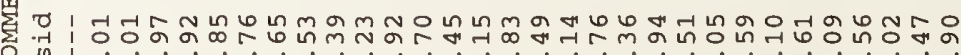

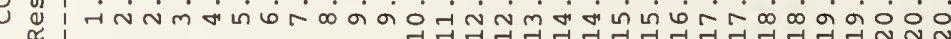
ᄂ n 药

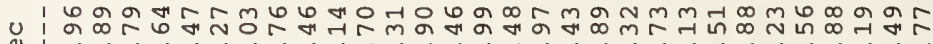
$\rightarrow$ व

约 范 完

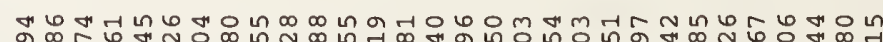
舀 $010.0 \%$

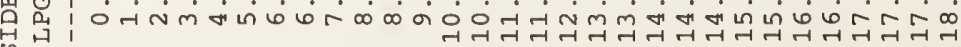
幽

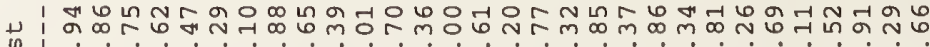
-

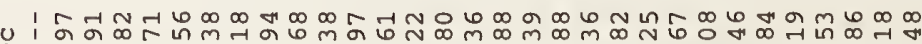
४ व . ज व

z 1 ศNm 


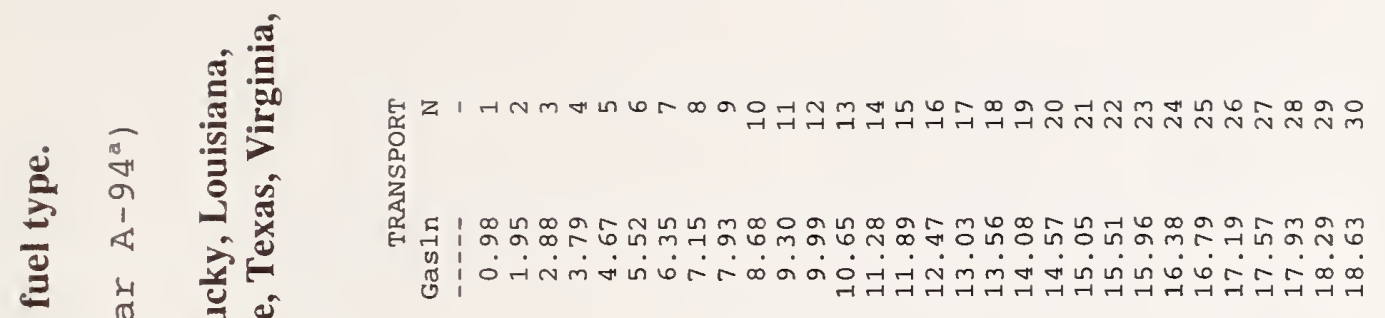

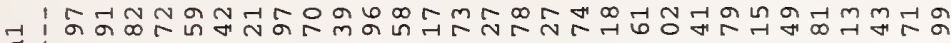
ठ 菧约 范 总

겅의

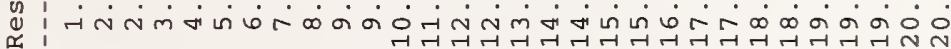

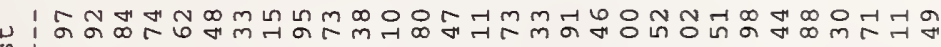
u व ।

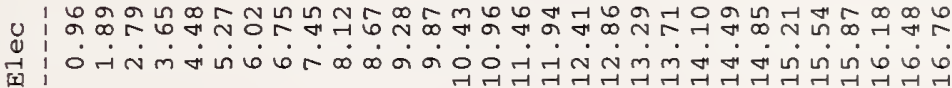

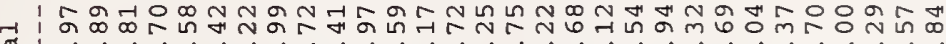
ठ ठ

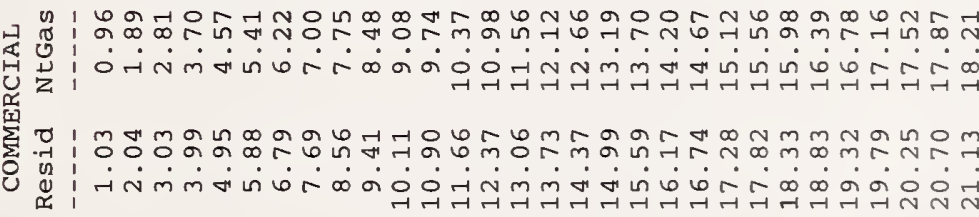
ᄂ $\rightarrow$ O ט

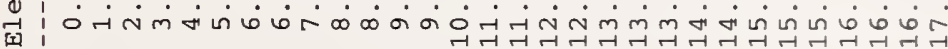

đI ப 空

क m ט 1 . 菏

ฟ a

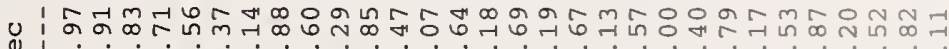
$\Rightarrow$ ठ

Z I

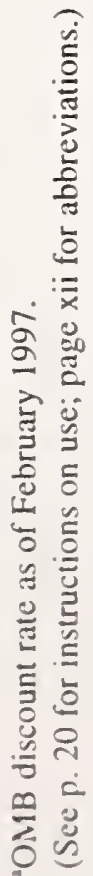




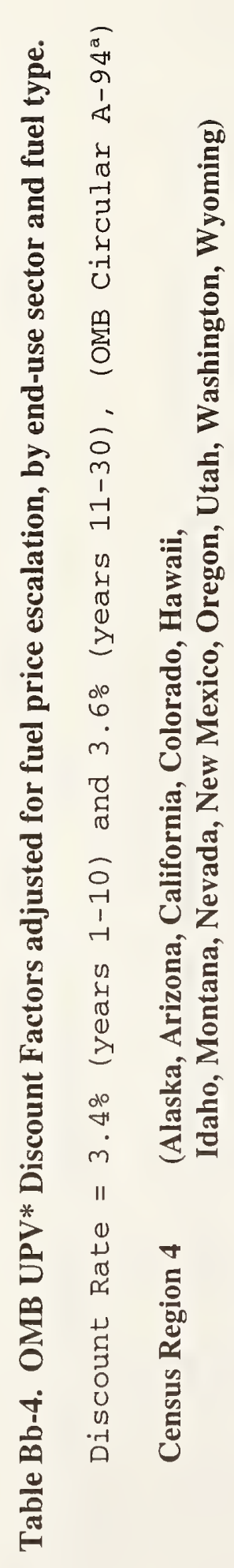

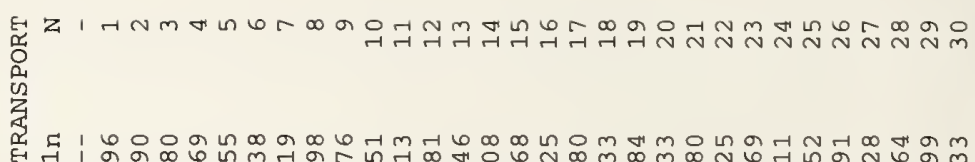

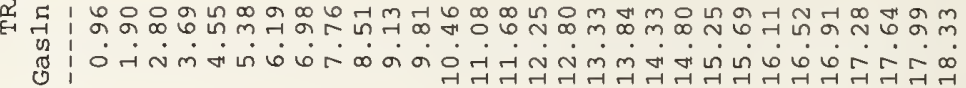

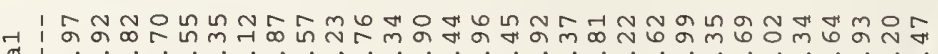
ठ

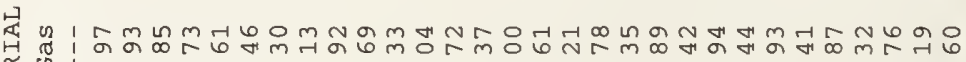
否艺 员

晃 ‘ Q ᄂ

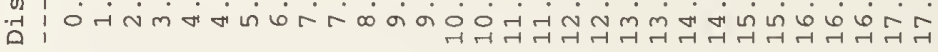
0 नूু -

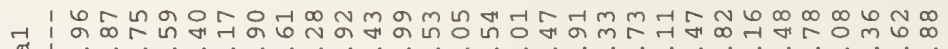
ठ 빌

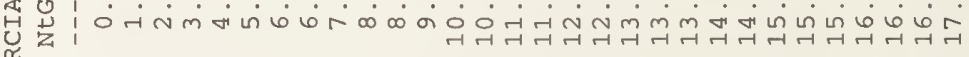

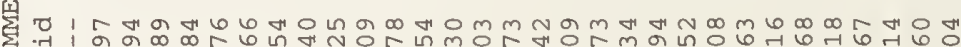
U व

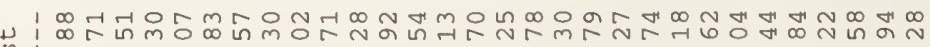
-

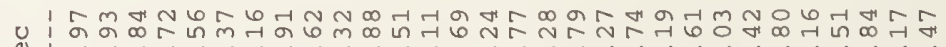

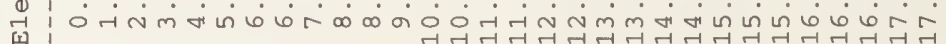

⿹ 范 Н

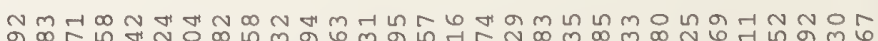

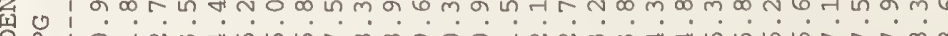

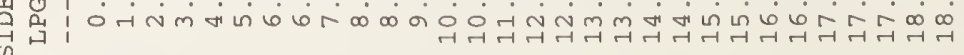
稆

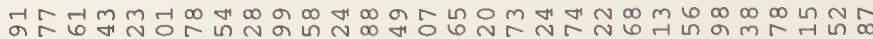

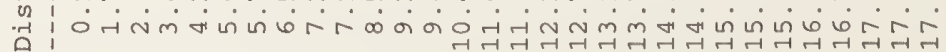

ט

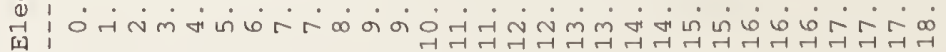

य न न 


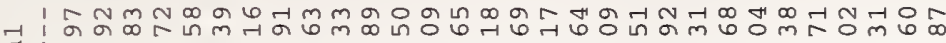

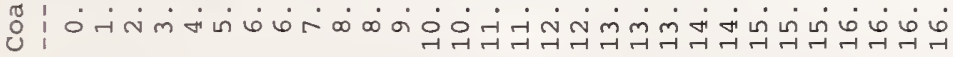

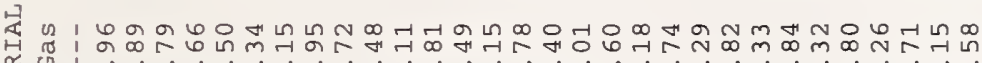

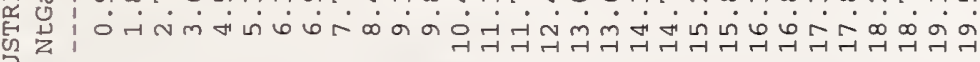
号 శ్ન

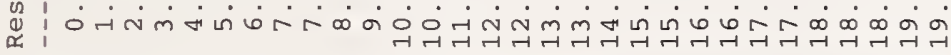

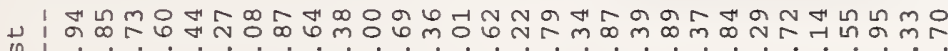

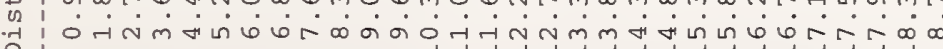

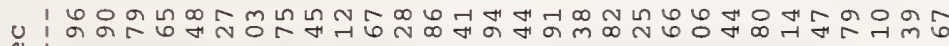

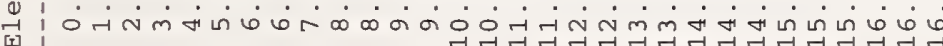

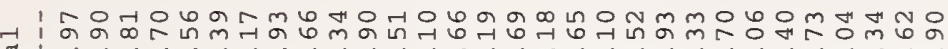
ठठ ठं

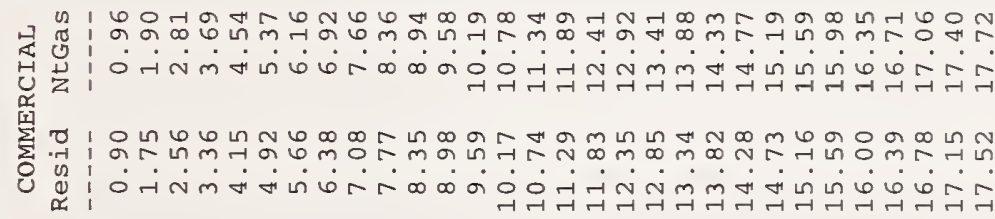

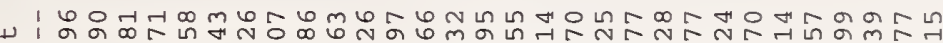

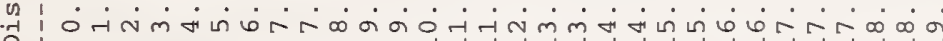

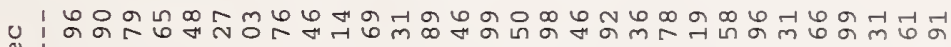

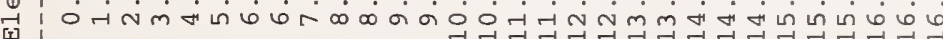

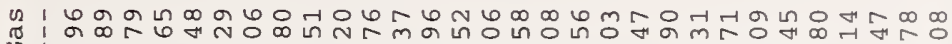
艺 语

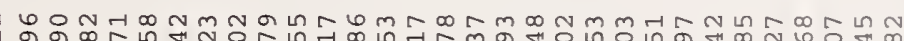

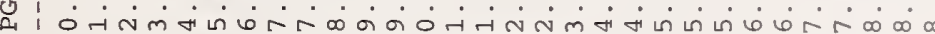

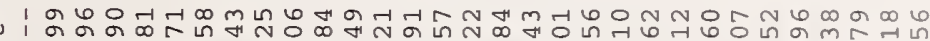

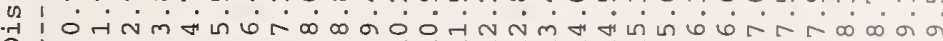

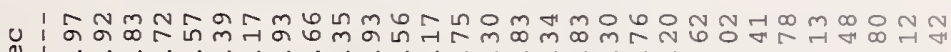

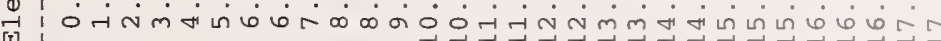

z। 


\section{Projected Average Fuel Price Indices and Escalation Rates (Real)}

Tables $\mathrm{Ca}-1$ through $\mathrm{Ca}-5$ present projected fuel price indices for the 4 Census regions and for the United States. These are factors which, when multiplied by annual energy costs computed at base-date prices, provide estimates of future-year costs in constant base-date dollars. The indices are based on endof-year energy prices. End-of-year indices are used because the discount factors provided in this report are based on the end-of-year discounting convention. Constant dollar costs are needed when discounting is performed with a real discount rate (i.e., one which does not include general price inflation).

\section{Example of How to Use the Indices:}

To estimate the price of industrial coal at the end of year 2006 in Connecticut (in constant 1997 dollars), go to Table Ca-1, find the year 2006 index for industrial coal (.99), and multiply by the price for industrial coal in Connecticut at the beginning of year 1997.

For further explanation of how to use these tables, see NIST Handbook 135.

Tables $\boldsymbol{C b}$-1 through $\mathbf{C b}-5$ present the projected average fuel price escalation rates (percentage change compounded annually) for selected periods from 1997 to 2026 for the four Census regions and for the overall United States. Note that these are real rates exclusive of general price inflation. Their use results in prices expressed in constant dollars.

The average fuel escalation rates consolidate the information provided by the indices in the Ca tables so that trends in projected price changes can be seen at a glance. They are provided primarily to accommodate computer programs (such as BLCC) which require price escalation rates as inputs.

Unless there is a compelling reason to use escalation rates, it is recommended that you use the indices in the $\mathrm{Ca}$ tables when you need estimates of future-year energy prices, since the indices include year-to-year information rather than averages over a number of years.

\section{Example of How to Use the Escalation Rates:}

To estimate the unit price of residential natural gas at the end of $2006\left(\mathrm{p}_{06}\right)$ in Wyoming using the DOE energy price escalation rates, go to Table Cb-4 and find the 1997-2001 and the 2001-2006 escalation rates for residential natural gas $(-0.8 \%$ for 5 years and $-0.4 \%$ for 5 years, respectively). Enter these values and the unit price of residential natural gas in Wyoming at the end of $1997\left(\mathrm{p}_{97}\right)^{3}$ into the following formula. Then solve for the 2006 energy price (stated in end of 1997 dollars):

$$
\begin{aligned}
p_{05} & =p_{97} x\left(1+e_{1}\right)^{k_{1}} \times\left(1+e_{2}\right)^{k_{2}} \\
& =p_{97} x(1-0.008)^{5} \times(1-0.004)^{5}
\end{aligned}
$$

\footnotetext{
${ }^{3}$ The price at the end of year 1997 (ending March 31, 1998) is the same as the price at the beginning of year 1998 (April 1, 1998). End-of-year 1997 is used here to maintain consistent notation.
} 


$$
=p_{97} \times 0.9416
$$

where $\mathrm{p}_{\mathrm{y}}=$ Price at end of year $\mathrm{y}$;

$\mathrm{e}_{\mathrm{i}}=$ Annual compound escalation rate for period $\mathrm{i}$ from the $\mathrm{Cb}$ tables (in decimal form); and

$\mathrm{k}_{\mathrm{i}}=$ Number of years over which escalation rate $\mathrm{e}_{\mathrm{i}}$ occurs.

Note that the compounded escalation rate factor $(0.9416)$ corresponds to the fuel price index in region 4 , residential natural gas, for the year 2006 in table Ca-4 (0.94).

The data in the tables which follow are reported for the four Census regions and the U.S. average. Figure B-1 presents a map showing the states corresponding to the four Census regions. The Census regions do not include American Samoa, Canal Zone, Guam, Puerto Rico, Trust Territory of the Pacific Islands, or the Virgin Islands. Analysts of federal projects in these areas should use data which are "reasonable under the circumstances," and may refer to the tables with U.S. average data for guidance. 


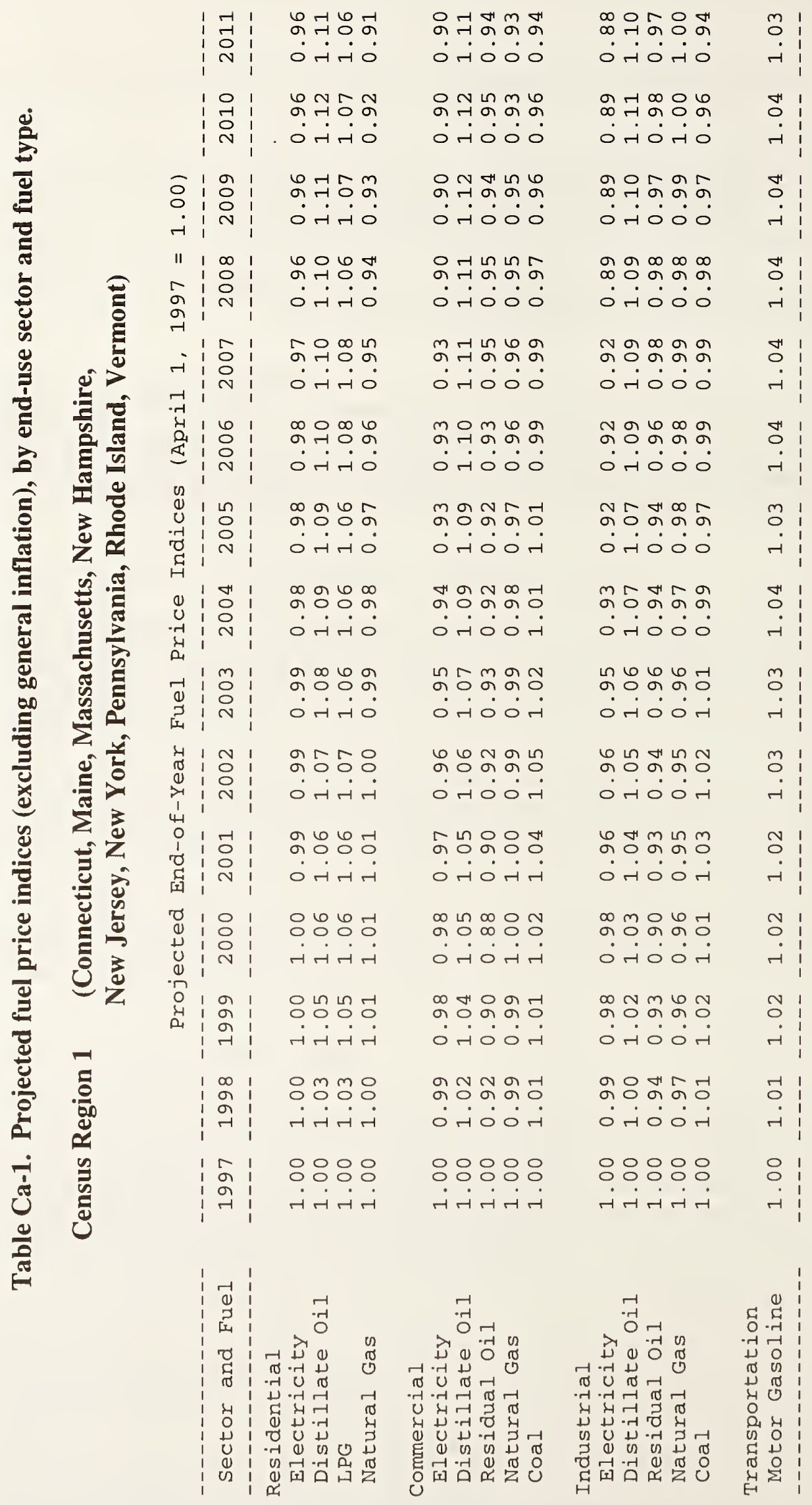




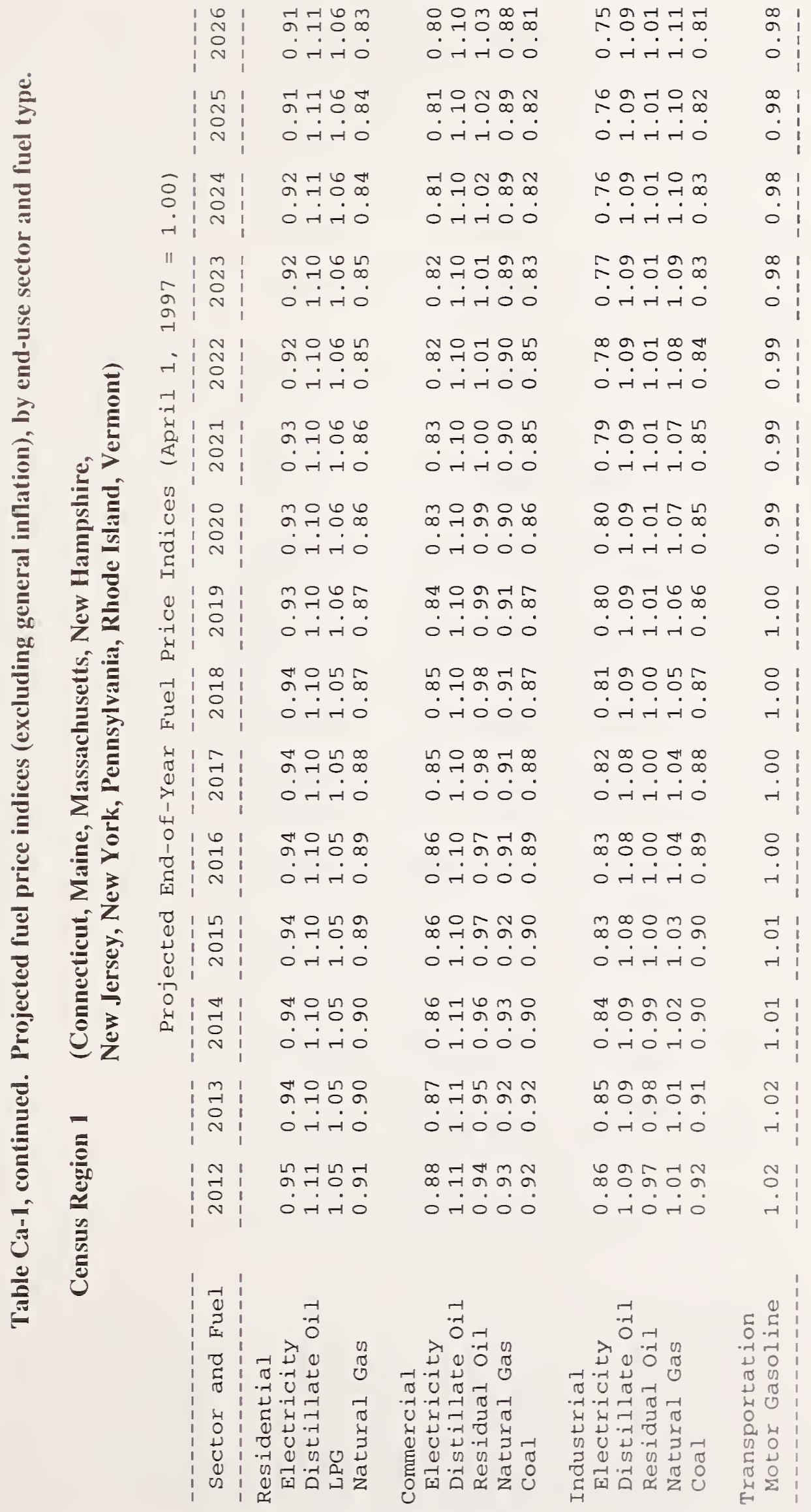




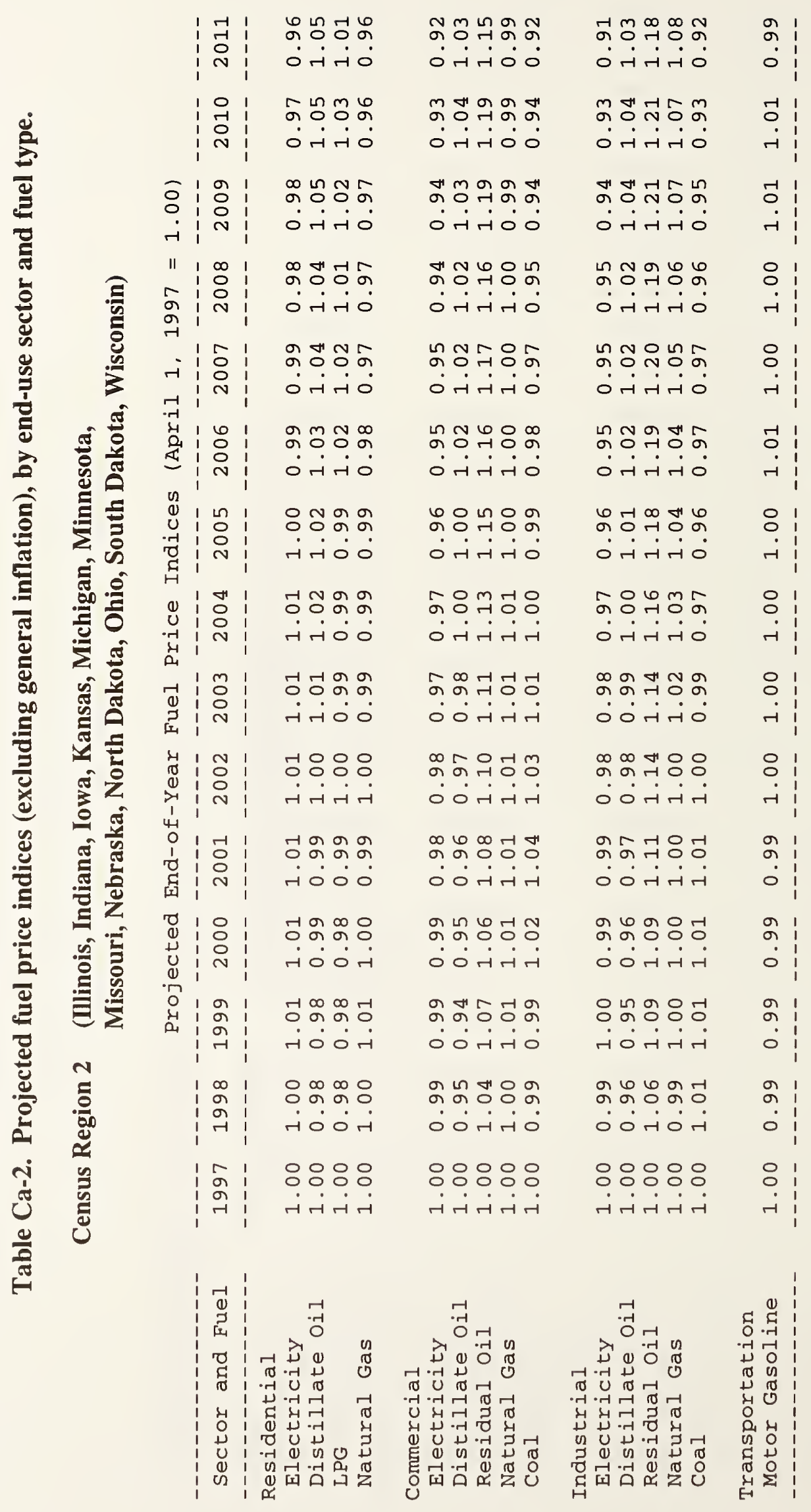




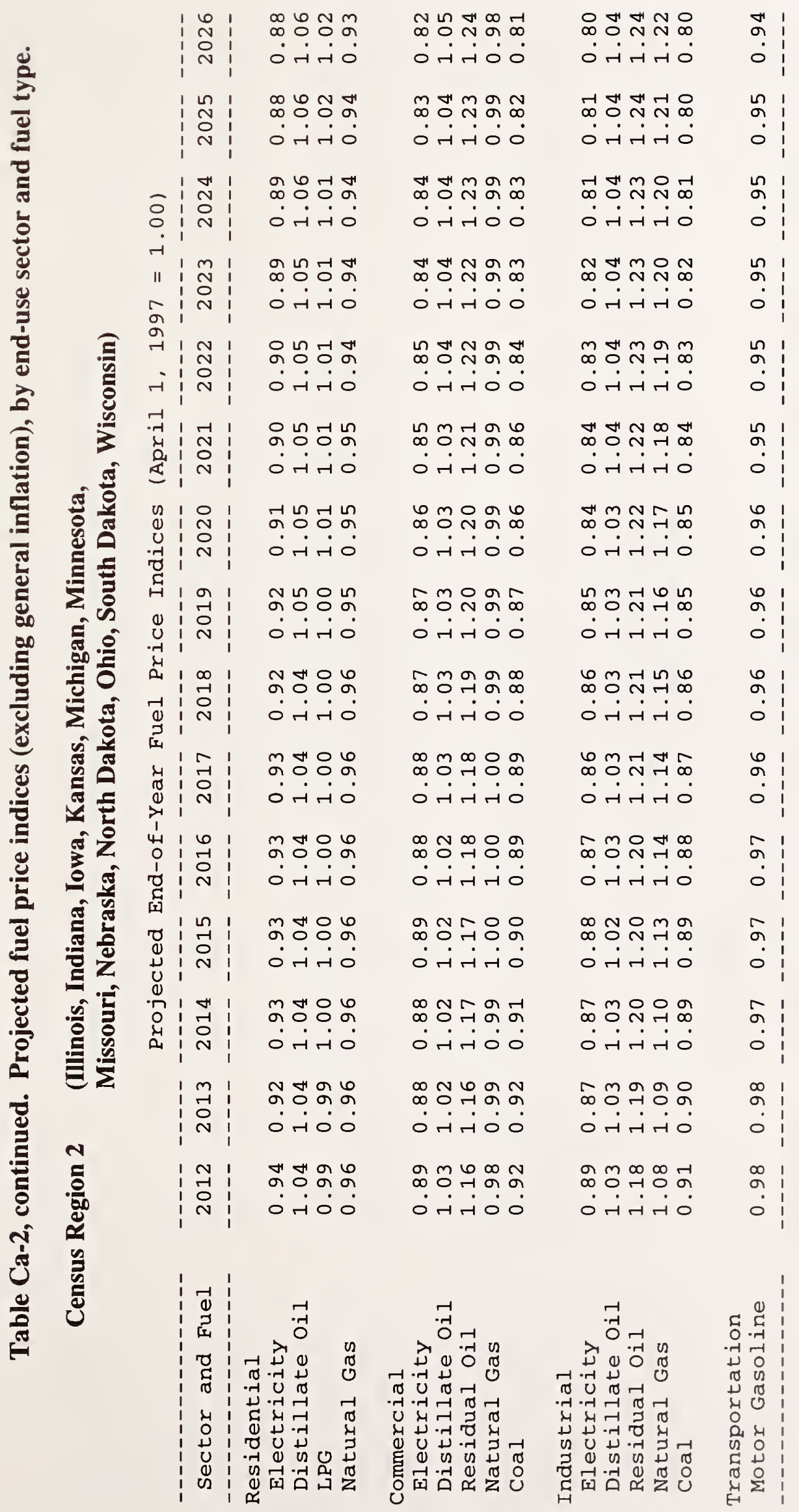



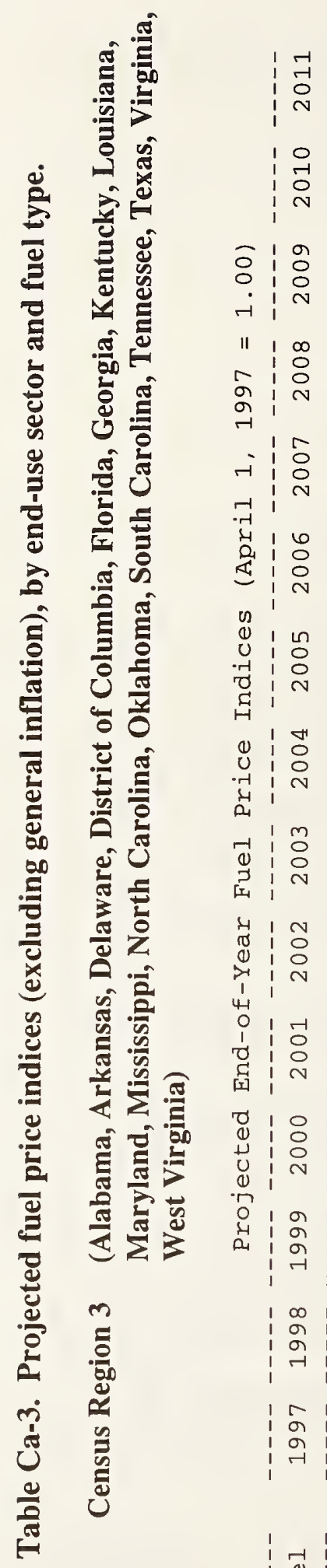

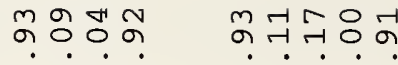

04 मां

거욱각의

मेन

꿍ํำ 늑유유

व.

० न

मिनंत्र

컥ㄱㄱ읭

$044 \mathrm{r}$

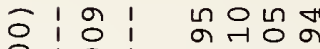

\begin{tabular}{l|l|l}
$\circ$ & 0 \\
0 & 0 \\
-1 & 0
\end{tabular}

ब. 다의

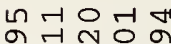

0 ना०

0 -1

$11 \infty 1100$

- 101100

เ 0 o

$\rightarrow$

- 151 ต

ตㅇำ

\begin{tabular}{l|l|l|l}
-1 & 0 & 1
\end{tabular}

मीन

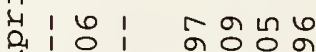

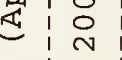

ํํㅇำ

is

०मत०

0 1 เ 1 ก

-r 01 \%.

०

(1) 1

$\infty \sim m \infty$

$\begin{array}{llll}0 & 1 & 0 & 1 \\ 0 & 1 & 0 & 1\end{array}$

aำ

0 -

.

0 न

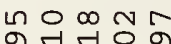

0ेंतिं

$6 \circ \infty \sim \infty$

.

ต유 응 बू

0 न

Haก

.

0 मतन

42

.

मनंति

$4 \infty \pi 6 \infty$

म न

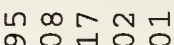

نम

4रा

क० तु० क

०मन नं

$6 \infty 6 \mathrm{~N}$

约

. ‥

0 न

न1

م

$04-0$

0 -

भ I

$\Rightarrow$ त 1 तंत्र

$\infty$ เก $\mathrm{m}$

.

1 다

1 1 ०००

ज N

ब म

व

૦

$\therefore \operatorname{NN}$

.. .

० नન

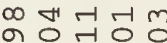

0 i

or mo $\mathrm{m}$

. .

व नंत

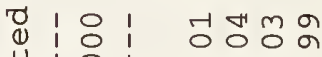

\pm 1001 .

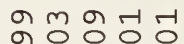

कㄷํㅇ응

०ंतिंत्

० न

나 ब ब न

का के । मंतं

응응응

तंतં

बํํㅇㅇㅇㅇ

०तनं०

$\infty$
a
a
1

궁당

निम

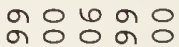

मेंति

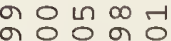

० नं तं

15
a
के
1

응ㅇㅇㅇㅇㅇ

मेंति

응ㅇㅇㅇㅇㅇ

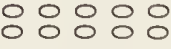

तन

तन

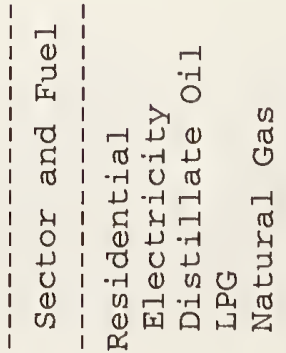

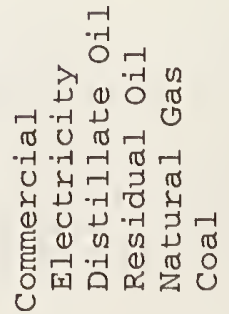

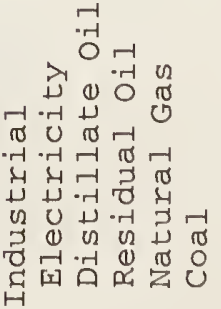

\begin{tabular}{l|l} 
गु & 1 \\
0 & 1 \\
- 1 & 1
\end{tabular}

เก

तi

๒ 1

तi

๒ 1

-i

เก 1

तi

ก

तi

\$

तं

मु

तi

0
0

तi

म 1

-i

\$

-i

0

-i

m 1

तं

N

मi

0 


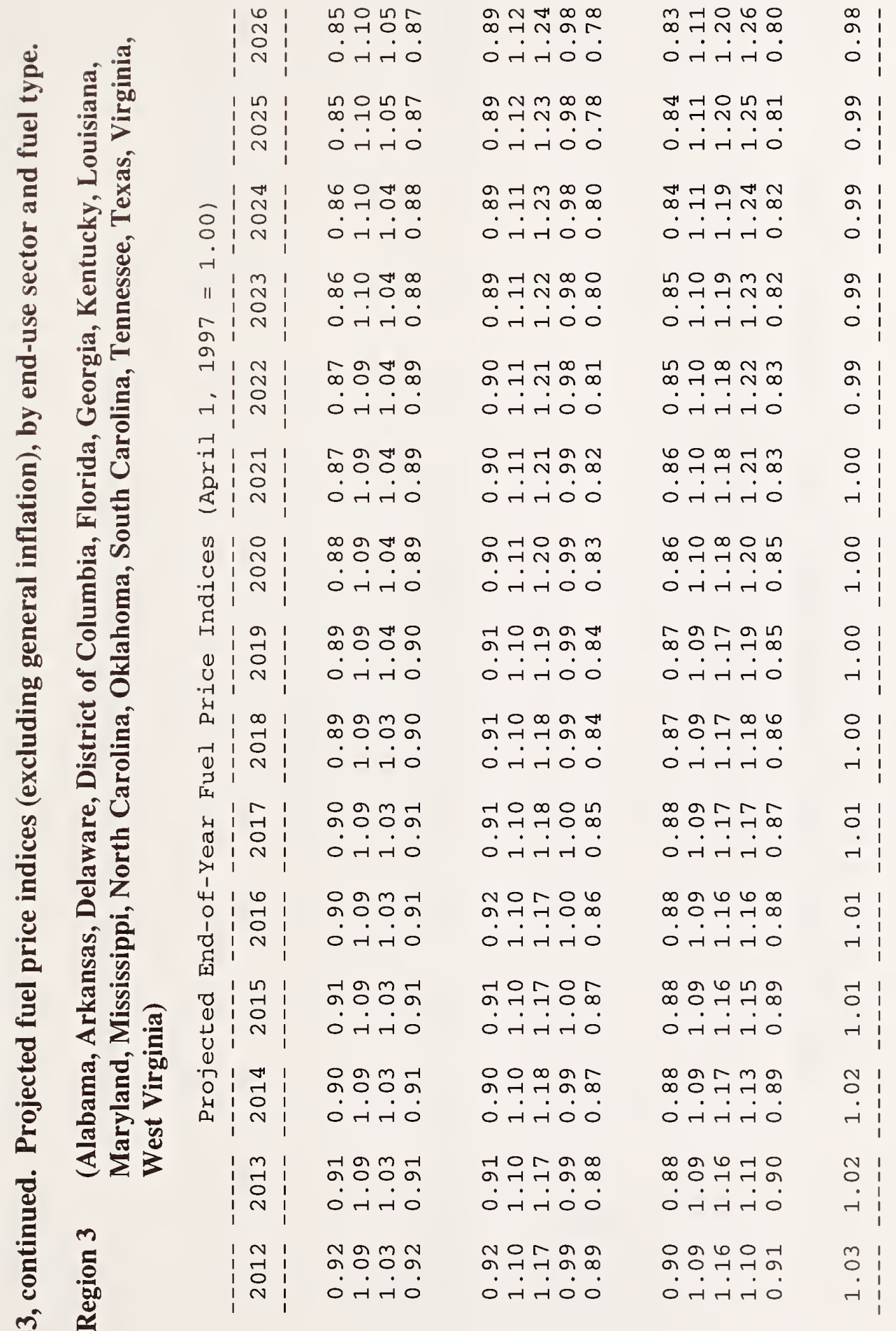

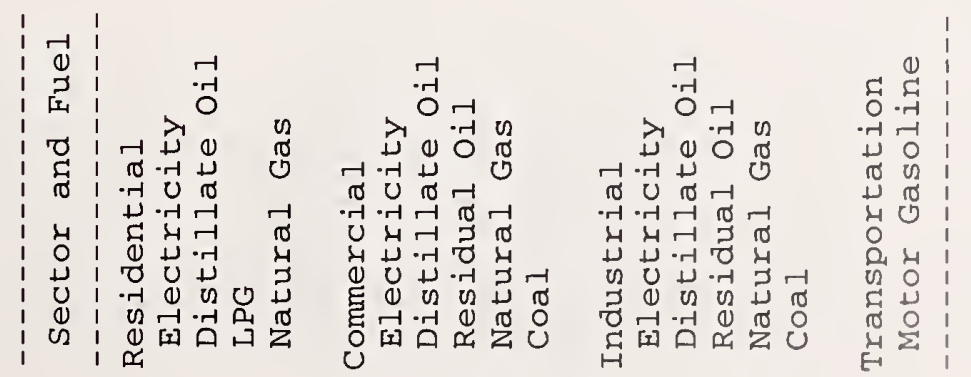




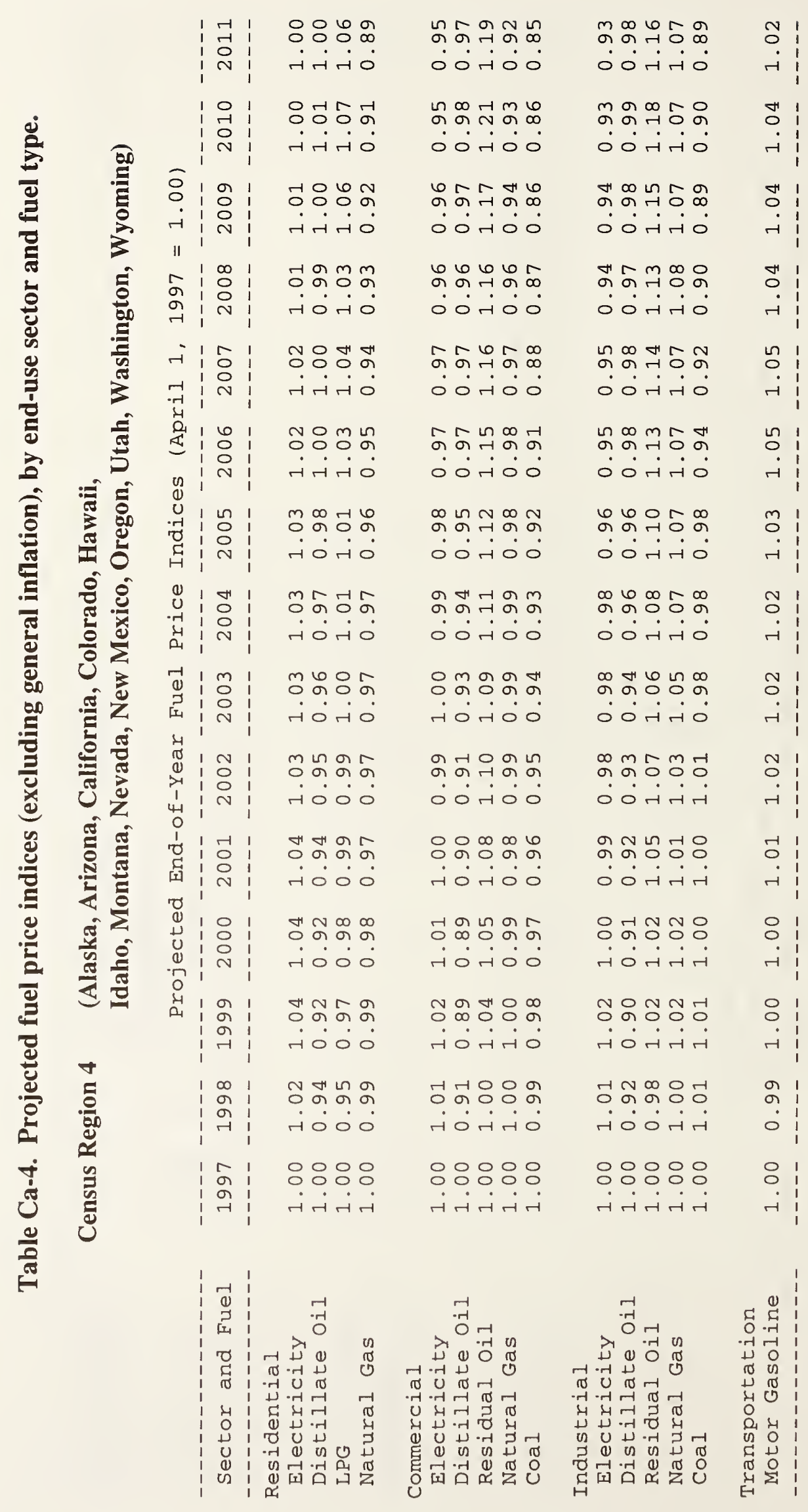




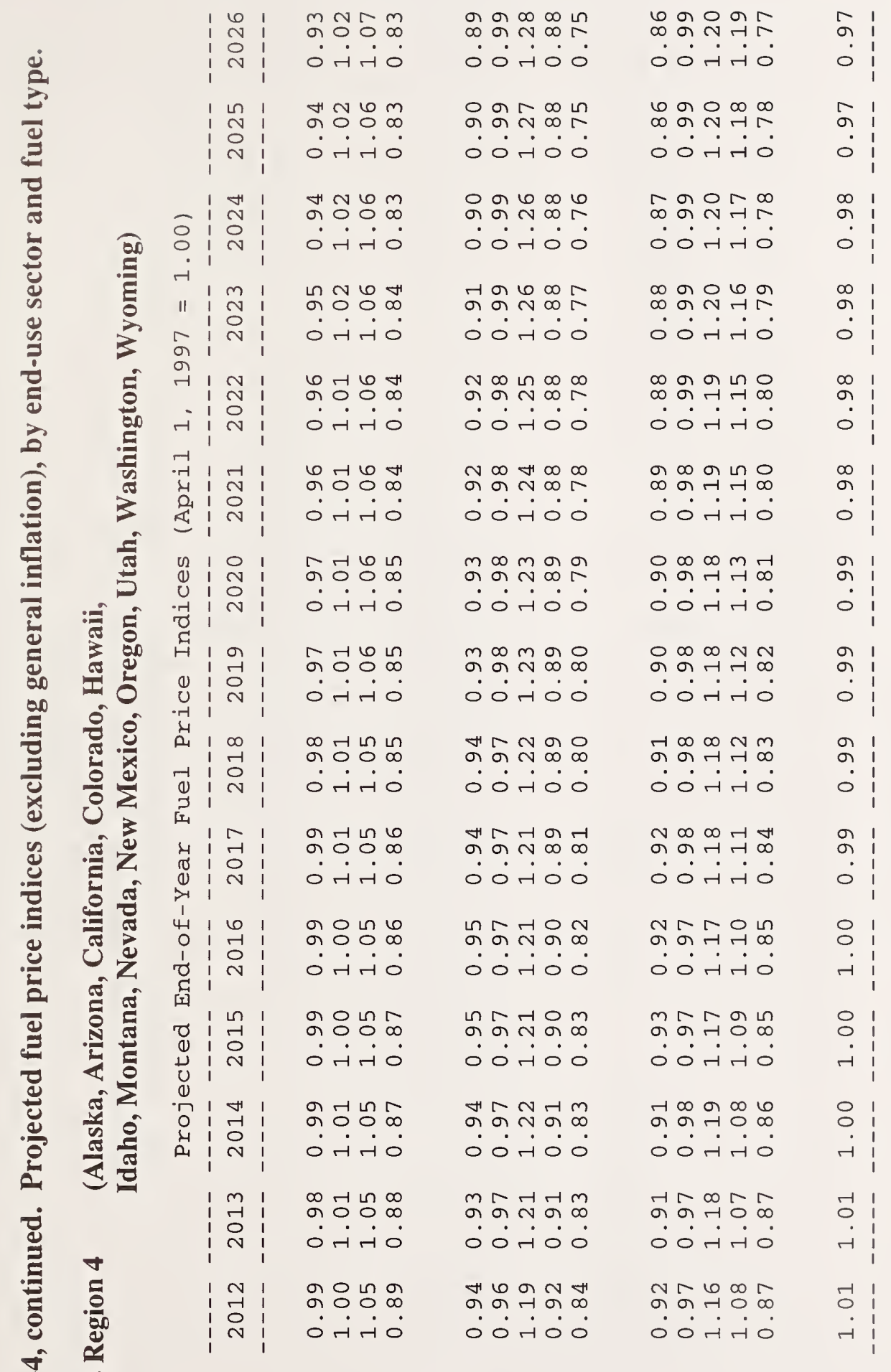

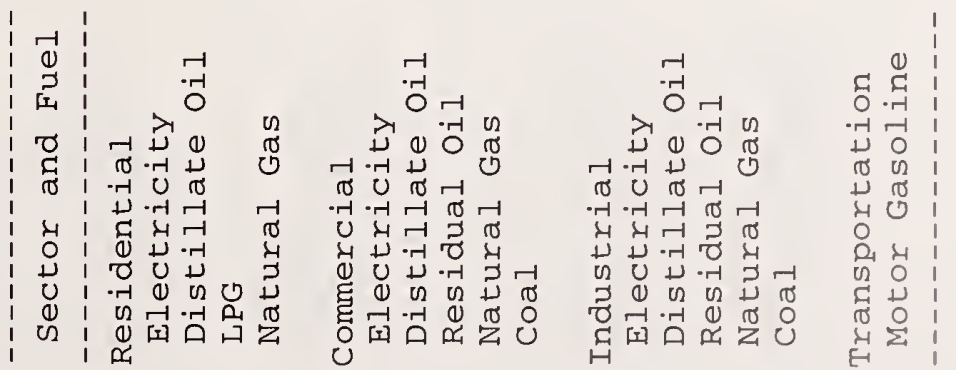




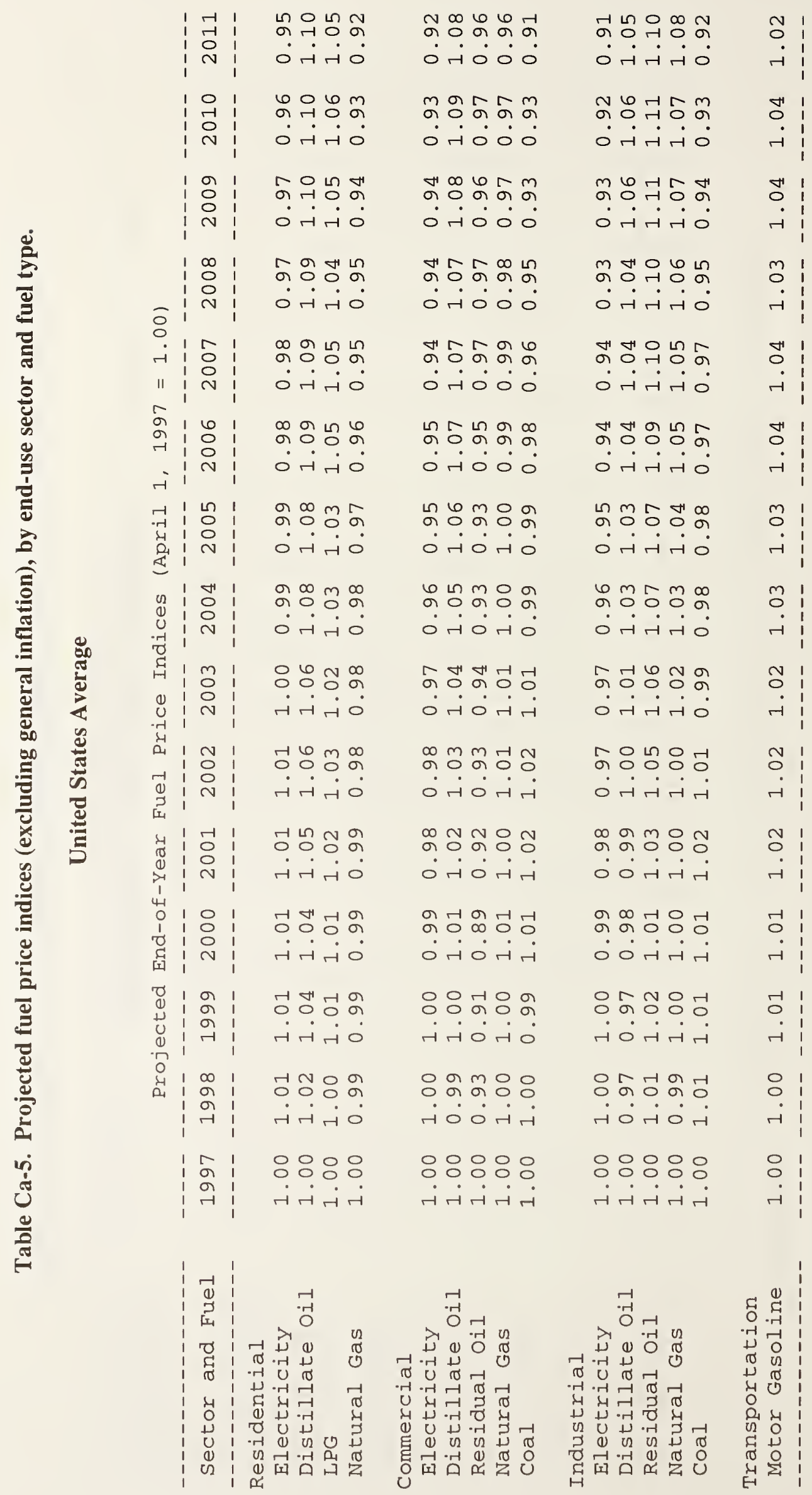


$\infty 06 \pi \quad \infty \infty \pi+5$ $\infty 00$ ar

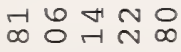

का

०ं

04 - 00

०ं

$\infty 06 \pi$

$\begin{array}{llll}\infty & 0 & 0 & 0 \\ 0 & 0 & 0\end{array}$

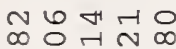

म

०म निं

के

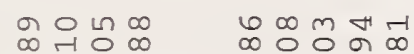

०िन

०ि

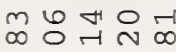

0ं

का

a 9 !n

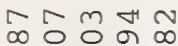

$\begin{array}{lll}m & 0 \\ 0 & \pi & \pi\end{array}$

०ंतंतं

०

०ं तं

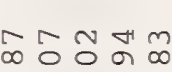

+ $60 \mathrm{~m}$ or

0 ना म०

0 तi तi

No

의 능

०म नं

0 ना नं 0

ti $10 \mathrm{~m}$

0 - -10

다의

$\infty$ 당 내

$\dot{0}-\dot{0}$

० तं

ㄴำ $\mathrm{m} 6$

$\infty$.

0 मान

다읭읭

$\infty$ 든는

0 -

०ंतं

6 ก $m \in$ เ

. ‥

긍유의

드의

० नां

०ं तं

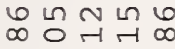

$\infty, \pi, \infty$

당ㅎㅇㅇㅡ

an $26 \pi$

०ंनं

○ं

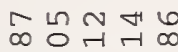

०ं

लू बून न

잉 न

$\infty \begin{aligned} & \infty \\ & \infty \\ & 0\end{aligned}$

०म 10

०ं

०ि

m ब

응 न

0 मां

0 तं००००

$\infty \begin{array}{lll}\infty & \text { मत } \\ 0 & \infty\end{array}$

०िन में

ल ब म न

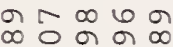

$0-10$

$\circ-100$

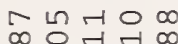

$\dot{0}-\dot{-i} \dot{0}$

लำ मे

क두 6

०ं

०ं

$\infty$ เ

$\infty 040 \infty$

$\dot{\circ} \dot{-1} \dot{0} \dot{0}$

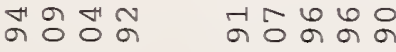

0 - 10

0 त 000

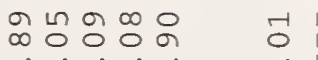

0 ना मी

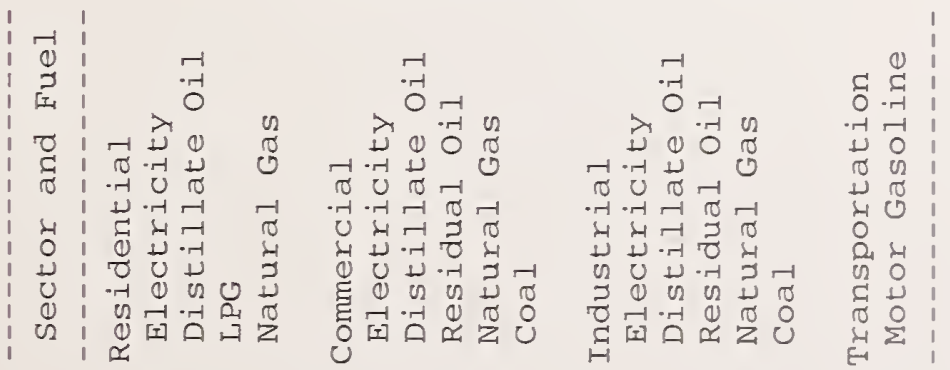


Table Cb-1. Projected average fuel price escalation rates, excluding general inflation, by end-use sector and fuel type.

Census Region 1 (Connecticut, Maine, Massachusetts, New Hampshire, New Jersey, New York, Pennsylvania, Rhode Island, Vermont)

\begin{tabular}{|c|c|c|c|c|c|c|}
\hline & & ercent & change & npounde & nually & \\
\hline----------------- & ----- & ----- & ---- & ----- & ---- & ---- \\
\hline & 1997 & 2001 & 2006 & 2011 & 2016 & 2021 \\
\hline Sector and Fuel & $\begin{array}{c}\text { to } \\
2001\end{array}$ & $\begin{array}{c}\text { to } \\
2006\end{array}$ & $\begin{array}{c}\text { to } \\
2011\end{array}$ & $\begin{array}{c}\text { to } \\
2016\end{array}$ & $\begin{array}{c}\text { to } \\
2021\end{array}$ & $\begin{array}{c}\text { to } \\
2026\end{array}$ \\
\hline 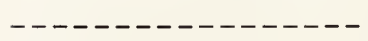 & ---- & ----- & ---- & ---- & ---- & - - - \\
\hline Residential & & & & & & \\
\hline Electricity & -0.1 & -0.4 & -0.4 & -0.3 & -0.3 & -0.3 \\
\hline Distillate Oil & 1.5 & 0.7 & 0.1 & -0.2 & 0.1 & 0.1 \\
\hline LPG & 1.4 & 0.4 & -0.3 & -0.2 & 0.1 & 0.1 \\
\hline Natural Gas & 0.1 & -1.0 & -1.0 & -0.6 & -0.6 & -0.6 \\
\hline Commercial & & & & & & \\
\hline Electricity & -0.8 & -0.8 & -0.7 & -0.9 & -0.7 & -0.7 \\
\hline Distillate Oil & 1.3 & 0.9 & 0.2 & -0.2 & 0.0 & 0.1 \\
\hline Residual oil & -2.6 & 0.7 & 0.1 & 0.7 & 0.5 & 0.5 \\
\hline Natural Gas & -0.0 & -0.7 & -0.7 & -0.4 & -0.4 & -0.3 \\
\hline Coal & 0.9 & -0.8 & -1.2 & -0.9 & -1.0 & -1.0 \\
\hline Industrial & & & & & & \\
\hline Electricity & -0.9 & -0.9 & -0.9 & -1.3 & -1.0 & -1.0 \\
\hline Distillate Oil & 0.9 & 1.0 & 0.2 & -0.2 & 0.1 & 0.1 \\
\hline Residual Oil & -1.9 & 0.7 & 0.1 & 0.7 & 0.2 & 0.1 \\
\hline Natural Gas & -1.3 & 0.7 & 0.3 & 0.7 & 0.7 & 0.7 \\
\hline Coal & 0.7 & -0.7 & -1.1 & -1.1 & -1.0 & -1.0 \\
\hline Transportation & & & & & & \\
\hline Motor Gasoline & 0.6 & 0.3 & -0.2 & -0.5 & -0.3 & -0.3 \\
\hline$-\cdots---------$ & - & & - & - & - & \\
\hline
\end{tabular}


Table Cb-2. Projected average fuel price escalation rates, excluding general inflation, by end-use sector and fuel type.

Census Region 2 (Illinois, Indiana, Iowa, Kansas, Michigan, Minnesota, Missouri, Nebraska, North Dakota, Ohio, South Dakota, Wisconsin)

\begin{tabular}{|c|c|c|c|c|c|c|}
\hline - - - & ---- & ---- & ----- & ---- & ----- & ---- \\
\hline & 1997 & 2001 & 2006 & 2011 & 2016 & 2021 \\
\hline Sector and Fuel & $\begin{array}{c}\text { to } \\
2001\end{array}$ & $\begin{array}{c}\text { to } \\
2006\end{array}$ & $\begin{array}{c}\text { to } \\
2011\end{array}$ & $\begin{array}{c}\text { to } \\
2016\end{array}$ & $\begin{array}{l}\text { to } \\
2021\end{array}$ & $\begin{array}{ll}\text { to } & \\
2026\end{array}$ \\
\hline 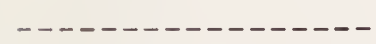 & $-\ldots-$ & -..- & -..- & $-\ldots$ & -..- & $-\ldots$ \\
\hline Residential & & & & & & \\
\hline Electricity & 0.3 & -0.4 & -0.7 & -0.5 & -0.6 & -0.6 \\
\hline Distillate Oil & -0.2 & 0.8 & 0.2 & -0.1 & 0.2 & 0.2 \\
\hline LPG & -0.3 & 0.6 & -0.1 & -0.3 & 0.2 & 0.2 \\
\hline Natural Gas & -0.2 & -0.3 & -0.4 & 0.1 & -0.4 & -0.3 \\
\hline Commercial & & & & & & \\
\hline Electricity & -0.4 & -0.7 & -0.7 & -0.7 & -0.7 & -0.7 \\
\hline Distillate Oil & -1.0 & 1.2 & 0.3 & -0.1 & 0.2 & 0.3 \\
\hline Residual Oil & 1.9 & 1.5 & -0.2 & 0.4 & 0.5 & 0.5 \\
\hline Natural Gas & 0.2 & -0.1 & -0.2 & 0.2 & -0.2 & -0.1 \\
\hline Coal & 0.9 & -1.2 & -1.1 & -0.7 & -0.9 & -1.1 \\
\hline Industrial & & & & & & \\
\hline Electricity & -0.4 & -0.7 & -0.8 & -0.9 & -0.9 & -0.8 \\
\hline Distillate Oil & -0.8 & 1.1 & 0.2 & -0.1 & 0.2 & 0.2 \\
\hline Residual Oil & 2.6 & 1.4 & -0.2 & 0.4 & 0.3 & 0.3 \\
\hline Natural Gas & -0.1 & 0.9 & 0.6 & 1.1 & 0.7 & 0.7 \\
\hline Coal & 0.4 & -0.9 & -1.1 & -1.0 & -0.8 & -1.1 \\
\hline Transportation & & & & & & \\
\hline Motor Gasoline & -0.2 & 0.3 & -0.3 & -0.5 & -0.2 & -0.2 \\
\hline----------------1 & ---- & ---- & ---- & ---- & ---- & ----- \\
\hline
\end{tabular}


Table Cb-3. Projected average fuel price escalation rates, excluding general inflation, by end-use sector and fuel type.

Census Region 3

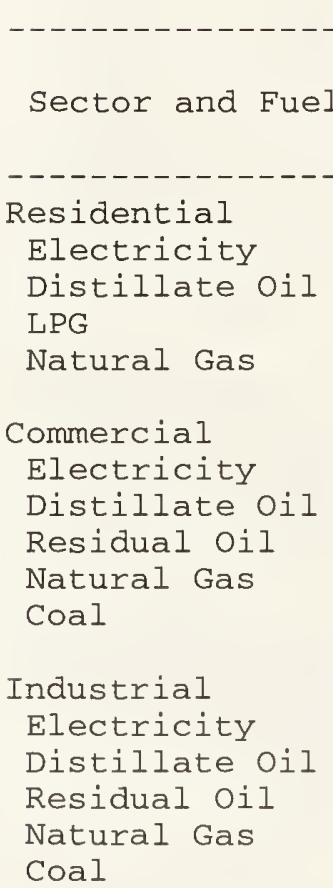

Transportation Motor Gasoline

(Alabama, Arkansas, Delaware, District of Columbia, Florida, Georgia, Kentucky, Louisiana, Maryland, Mississippi, North Carolina, Oklahoma, South Carolina, Tennessee, Texas, Virginia, West Virginia)

\begin{tabular}{|c|c|c|c|c|c|c|}
\hline & & Percentage & change & compounded & annually & \\
\hline------------------ & $\begin{array}{r}----- \\
1997\end{array}$ & $\begin{array}{r}---- \\
2001\end{array}$ & 2006 & $\begin{array}{r}----- \\
2011\end{array}$ & ----- & ----- \\
\hline Sector and Fuel & $\begin{array}{c}\text { to } \\
2001\end{array}$ & $\begin{array}{c}\text { to } \\
2006\end{array}$ & $\begin{array}{c}\text { to } \\
2011\end{array}$ & $\begin{array}{c}\text { to } \\
2016\end{array}$ & $\begin{array}{c}\text { to } \\
2021\end{array}$ & $\begin{array}{l}\text { to } \\
2026\end{array}$ \\
\hline $\begin{array}{l}\text { Residential } \\
\text { Resto }\end{array}$ & ----- & ----- & ----- & ----- & ----- & ----- \\
\hline $\begin{array}{l}\text { Electricity } \\
\text { Distillate Oil } \\
\text { LPG } \\
\text { Natural Gas }\end{array}$ & $\begin{array}{r}0.2 \\
1.2 \\
0.8 \\
-0.3\end{array}$ & $\begin{array}{r}-0.9 \\
0.7 \\
0.4 \\
-0.5\end{array}$ & $\begin{array}{r}-0.8 \\
0.1 \\
-0.2 \\
-0.8\end{array}$ & $\begin{array}{l}-0.6 \\
-0.1 \\
-0.2 \\
-0.3\end{array}$ & $\begin{array}{r}-0.6 \\
0.1 \\
0.1 \\
-0.5\end{array}$ & $\begin{array}{r}-0.6 \\
0.1 \\
0.2 \\
-0.4\end{array}$ \\
\hline $\begin{array}{l}\text { Commercial } \\
\text { Electricity } \\
\text { Distillate Oil } \\
\text { Residual Oil } \\
\text { Natural Gas } \\
\text { Coal }\end{array}$ & $\begin{array}{r}-0.3 \\
1.0 \\
2.5 \\
0.4 \\
0.6\end{array}$ & $\begin{array}{r}-0.7 \\
1.1 \\
1.3 \\
0.0 \\
-0.9\end{array}$ & $\begin{array}{r}-0.5 \\
0.2 \\
-0.1 \\
-0.4 \\
-1.6\end{array}$ & $\begin{array}{r}-0.4 \\
-0.1 \\
0.0 \\
0.1 \\
-1.0\end{array}$ & $\begin{array}{r}-0.3 \\
0.2 \\
0.5 \\
-0.3 \\
-1.1\end{array}$ & $\begin{array}{r}-0.3 \\
0.2 \\
0.6 \\
-0.2 \\
-0.9\end{array}$ \\
\hline $\begin{array}{l}\text { Industrial } \\
\text { Electricity } \\
\text { Distillate Oil } \\
\text { Residual Oil } \\
\text { Natural Gas } \\
\text { Coal }\end{array}$ & $\begin{array}{r}-0.3 \\
0.8 \\
2.2 \\
0.1 \\
0.6\end{array}$ & $\begin{array}{r}-0.9 \\
1.0 \\
1.3 \\
1.1 \\
-0.9\end{array}$ & $\begin{array}{r}-0.7 \\
0.2 \\
-0.1 \\
0.8 \\
-1.3\end{array}$ & $\begin{array}{r}-0.7 \\
-0.2 \\
0.0 \\
1.1 \\
-0.8\end{array}$ & $\begin{array}{r}-0.6 \\
0.2 \\
0.3 \\
0.9 \\
-1.0\end{array}$ & $\begin{array}{r}-0.6 \\
0.2 \\
0.3 \\
0.8 \\
-0.9\end{array}$ \\
\hline $\begin{array}{l}\text { Transportation } \\
\text { Motor Gasoline }\end{array}$ & $\begin{array}{r}0.9 \\
-----\end{array}$ & $\begin{array}{r}0.3 \\
-----\end{array}$ & $\begin{array}{r}-0.3 \\
-----\end{array}$ & $\begin{array}{r}-0.5 \\
-----\end{array}$ & $\begin{array}{r}-0.3 \\
-----\end{array}$ & $\begin{array}{r}-0.2 \\
-----\end{array}$ \\
\hline
\end{tabular}


Table Cb-4. Projected average fuel price escalation rates, excluding general inflation, by end-use sector and fuel type.

Census Region 4 (Alaska, Arizona, California, Colorado, Hawaii, Idaho, Montana, Nevada, New Mexico, Oregon, Utah, Washington, Wyoming)

\begin{tabular}{|c|c|c|c|c|c|c|}
\hline & & Per & tage ch & e compo & ed annu & \\
\hline 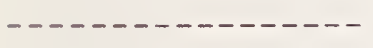 & ----- & ----- & ---- & ----- & ----- & ---- \\
\hline & 1997 & 2001 & 2006 & 2011 & 2016 & 2021 \\
\hline Sector and Fuel & $\begin{array}{c}\text { to } \\
2001\end{array}$ & $\begin{array}{c}\text { to } \\
2006\end{array}$ & $\begin{array}{c}\text { to } \\
2011\end{array}$ & $\begin{array}{c}\text { to } \\
2016\end{array}$ & $\begin{array}{c}\text { to } \\
2021\end{array}$ & $\begin{array}{c}\text { to } \\
2026\end{array}$ \\
\hline - - - - - - - - - - - - - - & $-\ldots-$ & --- & --- & ---- & ---- & --- \\
\hline Residential & & & & & & \\
\hline Electricity & 0.9 & -0.3 & -0.5 & -0.1 & -0.6 & -0.6 \\
\hline Distillate Oil & -1.6 & 1.3 & 0.0 & 0.1 & 0.1 & 0.1 \\
\hline LPG & -0.3 & 0.8 & 0.6 & -0.1 & 0.1 & 0.2 \\
\hline Natural Gas & -0.8 & -0.4 & -1.2 & -0.7 & -0.4 & -0.3 \\
\hline Commercial & & & & & & \\
\hline Electricity & 0.0 & -0.6 & -0.5 & 0.1 & -0.6 & -0.6 \\
\hline Distillate Oil & -2.6 & 1.5 & 0.0 & 0.0 & 0.2 & 0.2 \\
\hline Residual Oil & 1.9 & 1.4 & 0.6 & 0.2 & 0.6 & 0.6 \\
\hline Natural Gas & -0.4 & -0.2 & -1.1 & -0.6 & -0.3 & -0.2 \\
\hline Coal & -1.0 & -1.0 & -1.5 & -0.7 & -0.9 & -0.9 \\
\hline Industrial & & & & & & \\
\hline Electricity & -0.2 & -0.8 & -0.6 & -0.0 & -0.8 & -0.7 \\
\hline Distillate Oil & -2.1 & 1.3 & -0.0 & -0.1 & 0.2 & 0.2 \\
\hline Residual Oil & 1.1 & 1.6 & 0.5 & 0.3 & 0.3 & 0.3 \\
\hline Natural Gas & 0.3 & 1.2 & -0.2 & 0.6 & 0.8 & 0.8 \\
\hline Coal & 0.0 & -1.1 & -1.2 & -1.0 & -1.0 & -0.9 \\
\hline Transportation & & & & & & \\
\hline Motor Gasoline & 0.4 & 0.7 & -0.6 & -0.4 & -0.3 & -0.3 \\
\hline 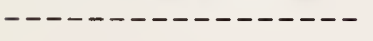 & -- & ---- & ---- & $-\ldots-$ & ---- & ---- \\
\hline
\end{tabular}


Table Cb-5. Projected average fuel price escalation rates, excluding general inflation, by end-use sector and fuel type.

\section{United States Average}

Sector and Fuel
Residential
Electricity
Distillate Oil
LPG
Natural Gas
Commercial
Electricity
Distillate Oil
Residual Oil
Natural Gas
Coal
Industrial
Electricity
Distillate Oil
Residual Oil
Natural Gas
Coal
Transportation
Motor Gasoline
------------

1997
to
2001
-----

Percentage change

2001
to
2006
-----

0.3

1.2

$-0.4$

0.5

$-2 \cdot 2$

0.1

0.5

$-0.4$

$-0.3$

0.7

$-0.1$

0.5

0.5
$-0.6$

0.8

0.6

$-0.5$

$-0.7$

1.0

0.8

$-0.3$

$-0.8$

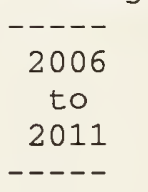

$-0.6$

0.1

0.0

$-0.8$

$-0.6$

0.1

0.1

$-0.6$

$-1.4$

$-0.9$

1.1

1. 2

1. 1

$-1.0$
$-0.7$
0.2
0.1
0.5

$-1.1$

0.4

$-0.3$ compounded

2011
to
2016
----

$-0.4$

$-0.2$

$-0.2$

$-0.3$

$-0.5$

$-0.2$

0.7

$-0.1$

$-0.9$

$-0.7$

$-0.2$

0.3

1. 0

$-1.1$

0.1

0.5

$-0.3$

$-0.9$

$-0.5$

0.1

0.5

$-0.2$

$-1.0$

$\begin{array}{rr}-0.7 & -0.7 \\ 0.2 & 0.2 \\ 0.3 & 0.3 \\ 0.7 & 0.8 \\ -1.0 & -0.8\end{array}$

$-0.5$

$-0.3$

$-0.2$ 


\section{Factors for Updating Appliance Label Values}

(In Compliance With the Energy Conservation Mandatory Performance Standards for New Federal Residential Buildings (10 CFR 435))

Compliance with energy conservation performance standards for new federal residential buildings requires calculation of a building's energy costs, including appliance costs. For this purpose, label values for gas and electric water heaters are given in the federal micro-computer program, COSTSAFR, as $\$ 176$ and $\$ 406$ per year, respectively, in 1987 dollars, and for refrigerator/freezers, as $\$ 61$ per year in 1987 dollars. To adjust 1987 prices to 1995 prices, multiply these 1987 label values by the factors below.

Table D. Factors for updating appliance label values from 1987 to 1996 dollars.

\begin{tabular}{ll}
\multicolumn{1}{c}{ Fuel } & Factor \\
\hdashline Gas & 1.15 \\
Electricity & 1.14
\end{tabular}

Note: the author requests that users of this table notify her at sieglinde.fuller@nist.gov [fax (301) 2086936] if this information is still needed for its intended purpose. If no response is received between April 1997 and April 1998, this table will be dropped from future editions of this report. 


\section{PART II: ENERGY PRICE INDICES FOR PRIVATE SECTOR LCC ANALYSIS}

This section presents tables of projected nominal (i.e., including inflation) fuel price indices for four fuels in the residential sector and five fuels in the commercial sector for each of the years from 1997 through 2026. These price indices are based on the DOE energy price projections, reported in part I-B of this document, used to calculate the FEMP and OMB UPV* factors for energy costs. The tables are provided as an update to similar tables originally published in Comprehensive Guide for Least-Cost Energy Decisions (NBS SP 709).

As a convenience for the user, the indices include the effect of four alternative, hypothetical rates of general price inflation: $3,4,5$, and $6 \%$. Selection of these rates is intended in no way to suggest what actual rates might be. Use of the indices produce price estimates which are in current dollars, inclusive of general price inflation. Current dollar prices are needed when discounting is performed with discount rates that include general price inflation (i.e., nominal or market discount rates).

The indices based on inflation rates of $3,4,5$, and $6 \%$ allow the analyst to perform evaluations based on the assumption of a positive rate of general price inflation that changes the purchasing power of the dollar. Performing evaluations in current dollars is sometimes preferred for private investment decisions, primarily because it facilitates the treatment of taxes.

The indices in Tables S-1 through S-5 are derived from the indices reported in Tables Ca-1 through Ca-5 by means of the following equation:

$$
I_{S}=I_{C} x(1+g)^{N},
$$

where $\quad \mathrm{I}_{\mathrm{S}}=$ index found in Tables S-1 through S-5;

$\mathrm{I}_{\mathrm{C}}=$ index found in Tables Ca- 1 through Ca-5;

$\mathrm{g}=$ annual rate of general price inflation in decimal form; and

$\mathrm{N}=$ number of periods, in this case equal to the year of the index minus 1997.

\section{Example of How to Use the Indices:}

Suppose you wish to estimate the annual cost of natural gas for a house in Maryland in year 2001, given the annual cost at beginning-of-year 1997 (April 1) prices, and you expect an annual inflation rate of 3\% per year. From table S-3, find the column with residential natural gas indices at an inflation rate of $3 \%$; then locate the index for the year 2001. This index is 1.11. Multiply the annual cost at the beginning-ofyear 1997 price to find the estimated annual cost at end-of-year 2006 prices.

If this annual cost in year 2001 prices is to be discounted to present value, you must use a nominal discount rate that includes the same assumption with regard to general price inflation (3\% in this example). To obtain a present value cost over the entire study period, the present value calculations must be repeated for each year that there are natural gas costs, and the results summed. (UPV factors are not given for private sector use because of the large number of tables required to cover potential discount rates that might be used by the analyst.) The BLCC computer program can perform LCC analyses using 
any inflation rate and discount rate, in constant or in current (market) dollars. The DISCOUNT program, included with BLCC, can compute UPV* factors based on DOE energy price escalation rates using any inflation rate and discount rate. (See page iv for more information on these programs.) Of course, the private sector analyst may use the UPV factors reported in Part I, provided the analysis is performed in constant dollars and the desired discount rate corresponds to the DOE or OMB discount rates used in Part I.

For further explanation of the use of these indices, see NBS Special Publication 709, appendix B, Part I.

The data in the tables that follow are reported for the four Census regions and the U.S. average. Figure B-I presents a map showing the states corresponding to the four Census regions. The Census regions do not include American Samoa, Canal Zone, Guam, Puerto Rico, Trust Territory of the Pacific Islands, or the Virgin Islands. Analysts of federal projects in these areas should use data which are "reasonable under the circumstances," and may refer to the tables with U.S. average data for guidance. 


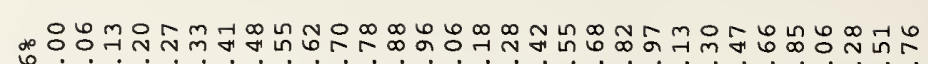
n

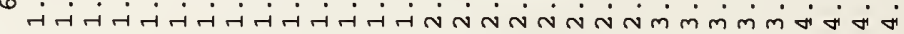

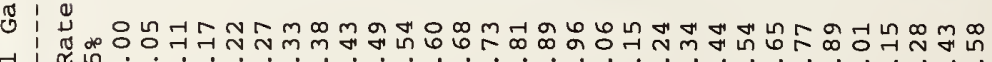

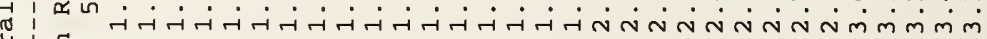
空

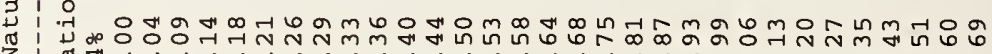

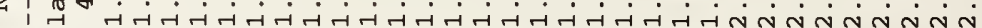
要

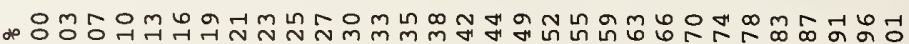

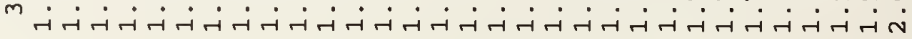

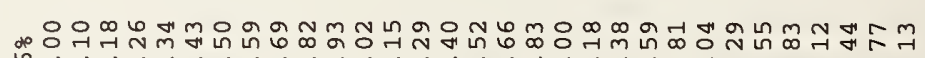

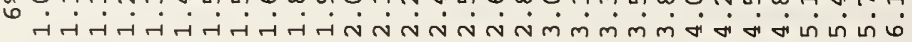

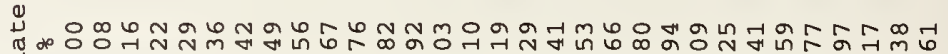
(1)

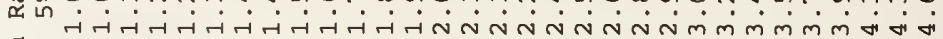
รี

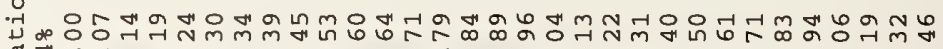

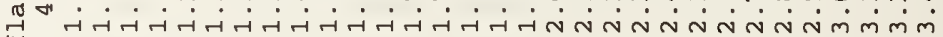
空

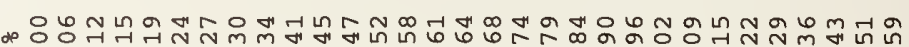

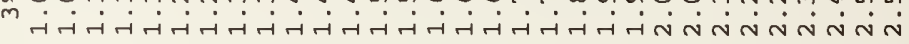

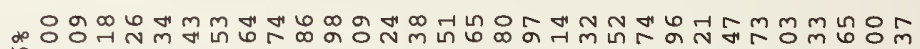

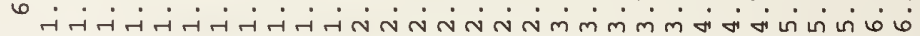
岁

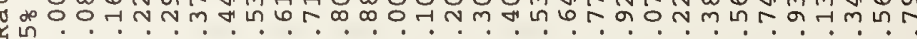

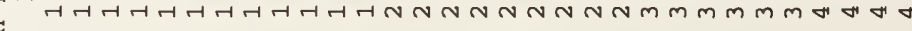
5

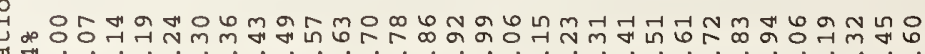

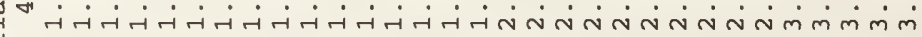
5

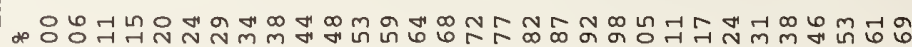

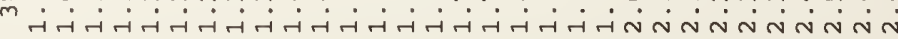

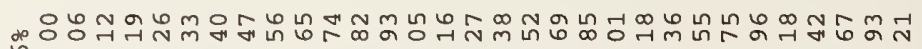

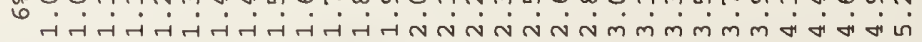
ते

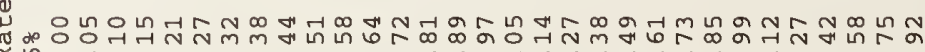

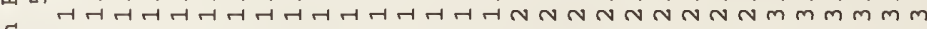
ธ

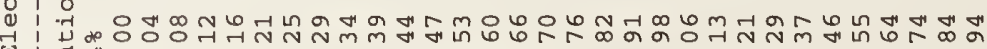

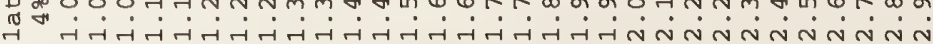
๕

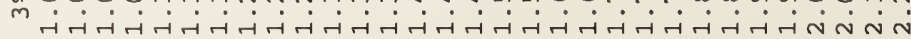

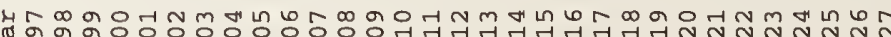

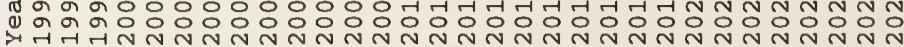




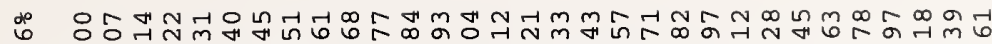

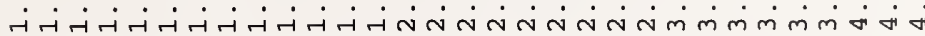

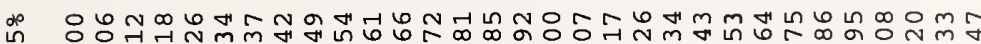
-

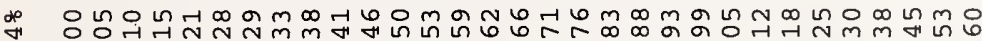
-

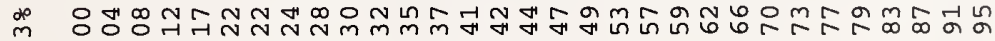

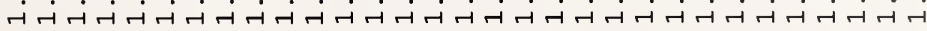

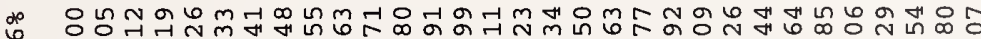

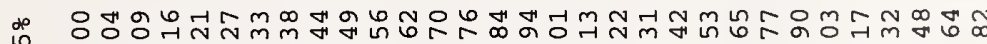
-i નi નi

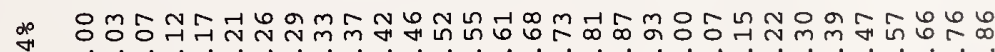

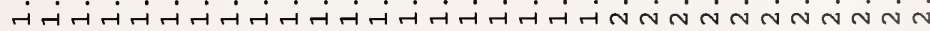

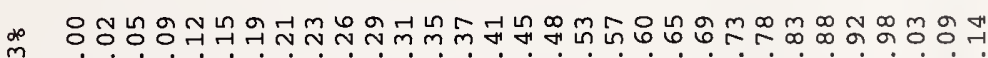
-

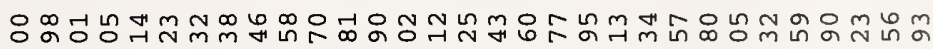
-

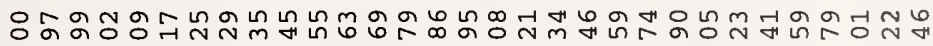

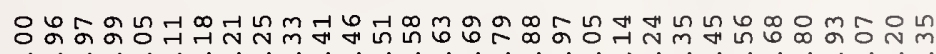
-i 00 0

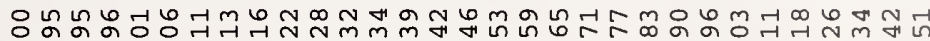
-i 0.

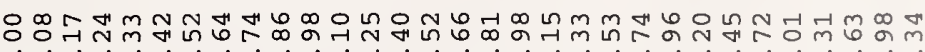
-i ri ri

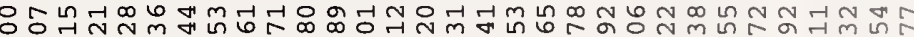

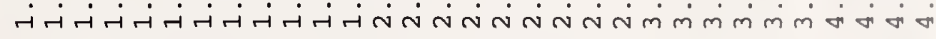

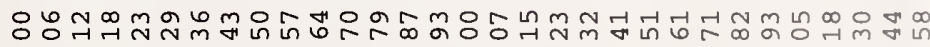

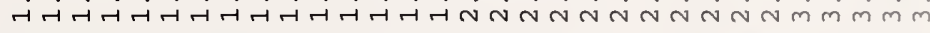

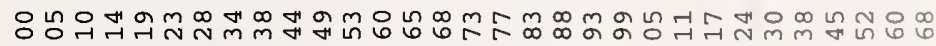

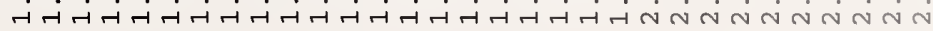

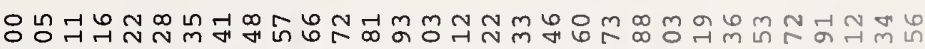

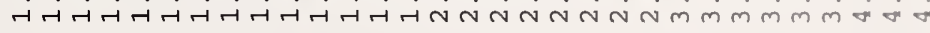

\&

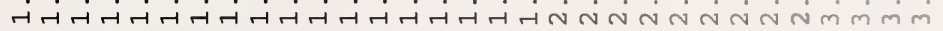

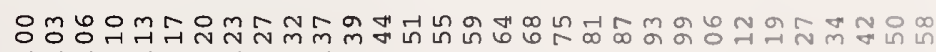

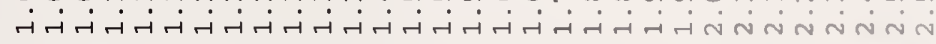




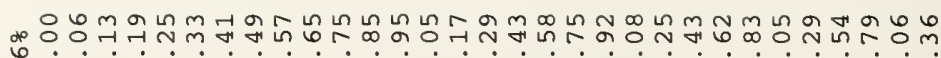

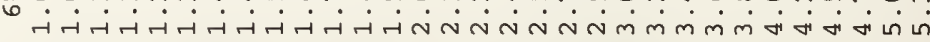
لّ๊

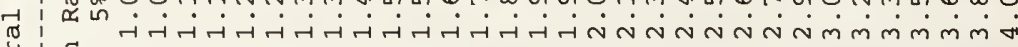
范

崩

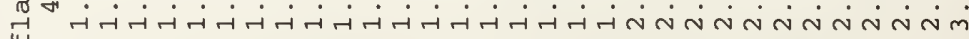
焉

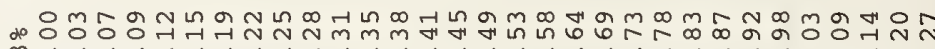

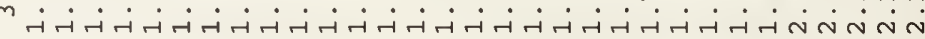

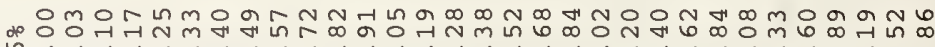

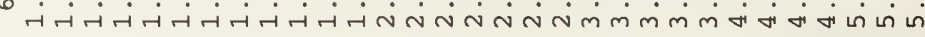

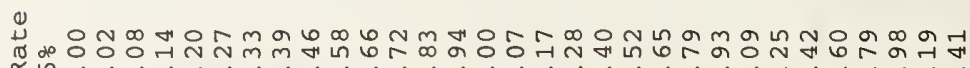
5 चี

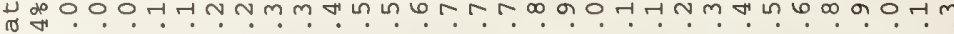

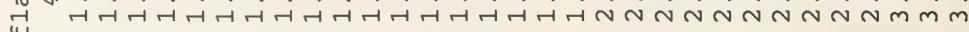
苟

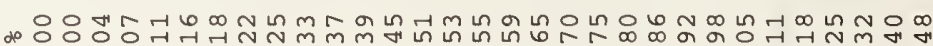

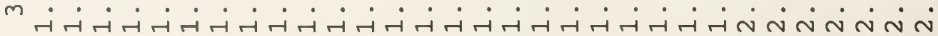

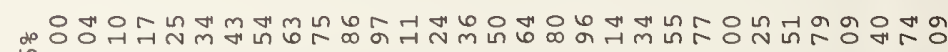

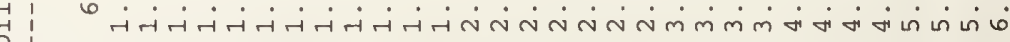
岁 ש̊口 ธ์

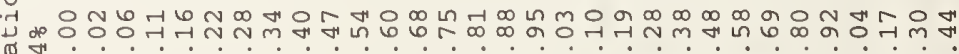

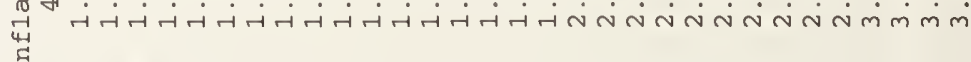

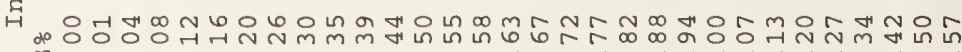

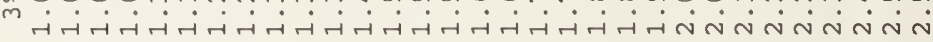

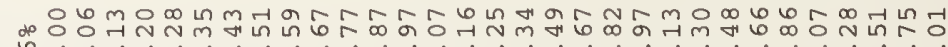

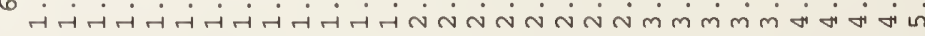
is ⿹弋工

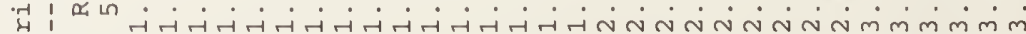
บ)

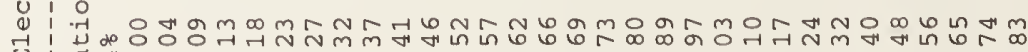
嵌

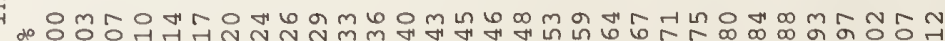

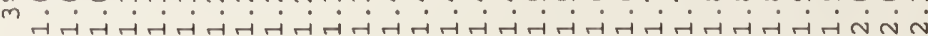

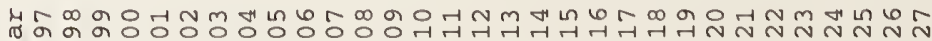
ब 


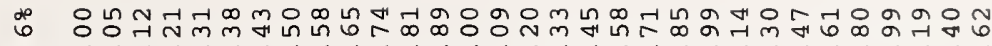

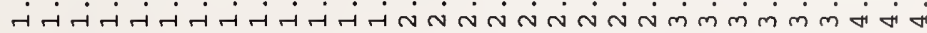

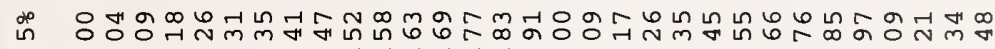

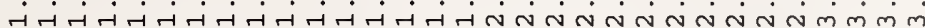

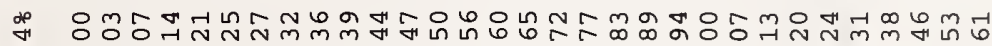

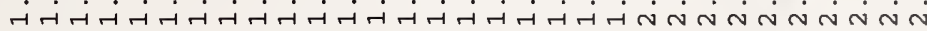

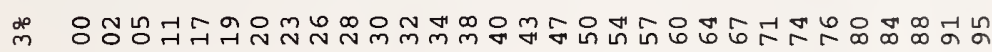

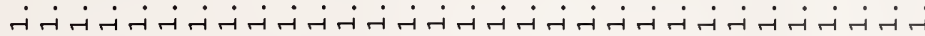

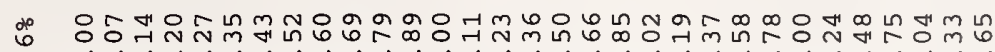

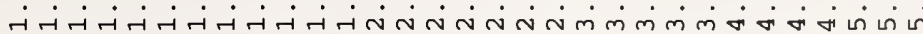

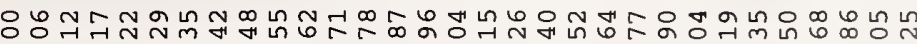

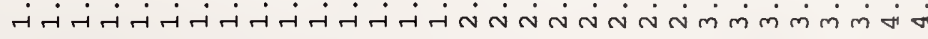

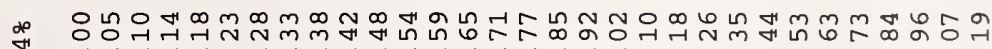
㞾

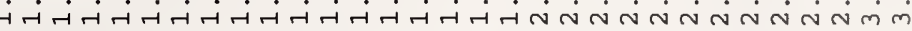

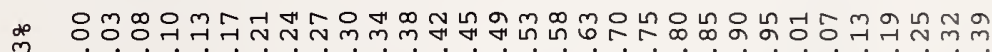

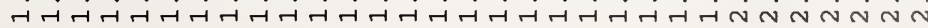

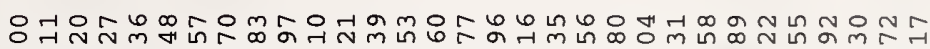

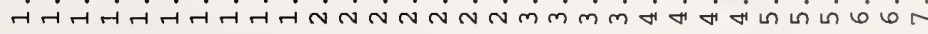

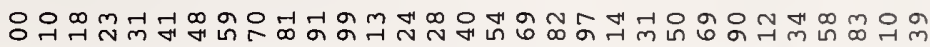

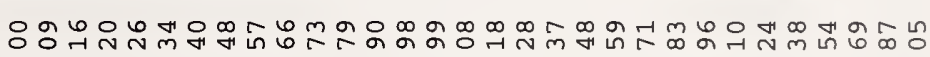

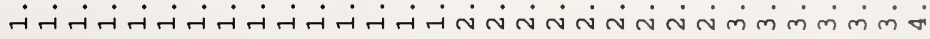

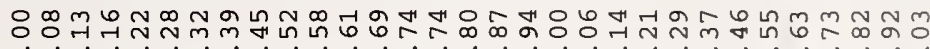

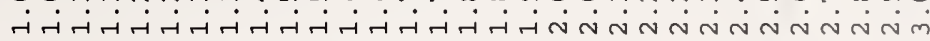

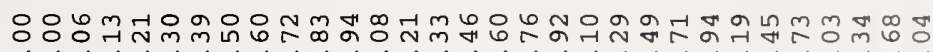

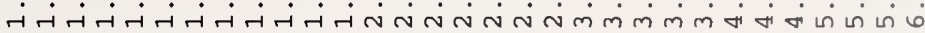

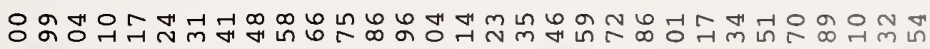

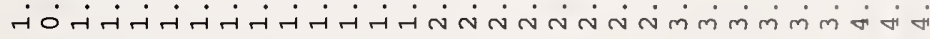

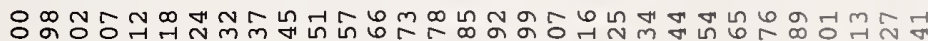

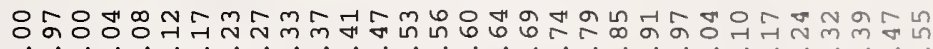
-iöri

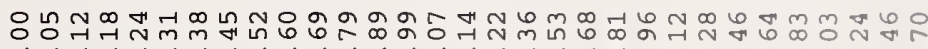

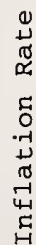

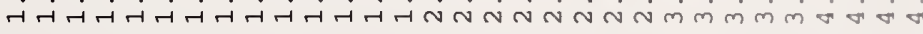

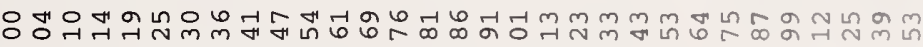

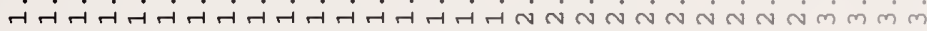

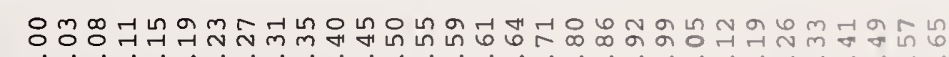

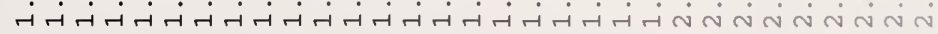




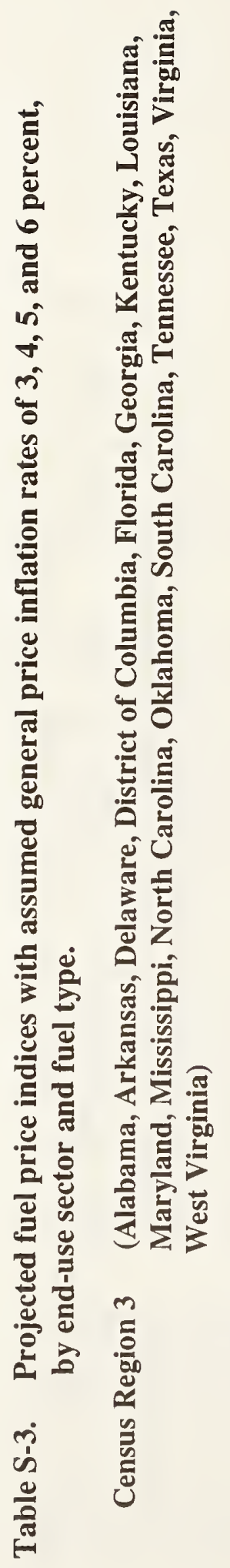

苟 孚 ना 出

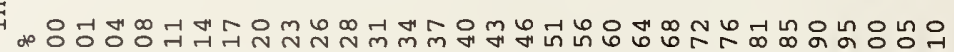

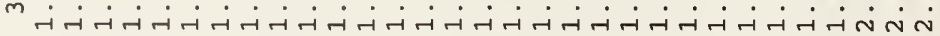
嵌

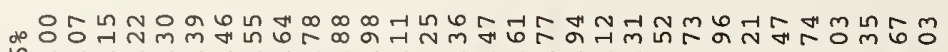

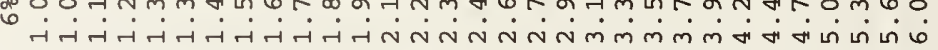
$\stackrel{1}{7}$ 幽 थ c.

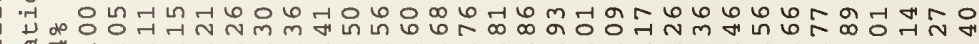

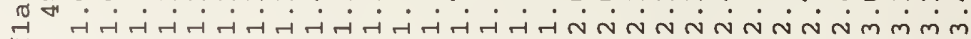
崖

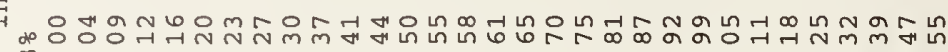

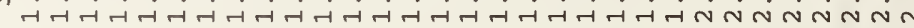

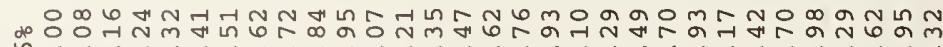

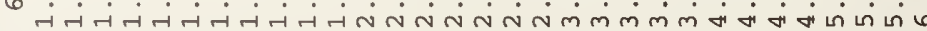

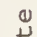

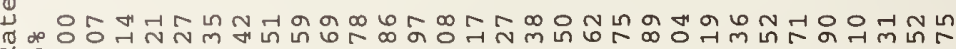
$\rightarrow 1$ c. H

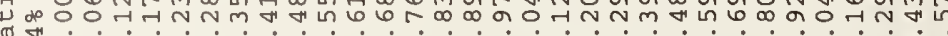
崔

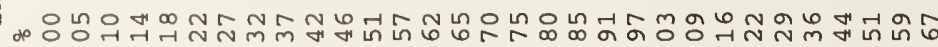

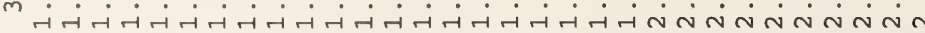

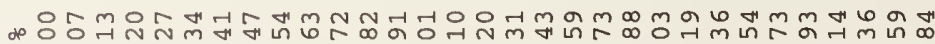

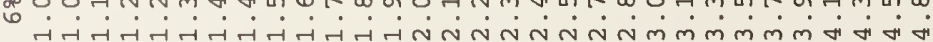
空 1 嵌 ๓ 5 苟

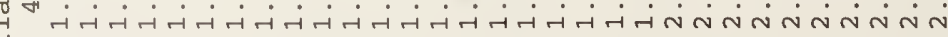
点

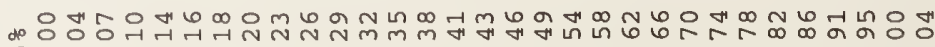

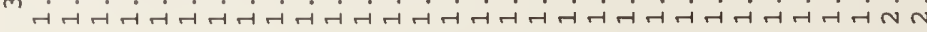

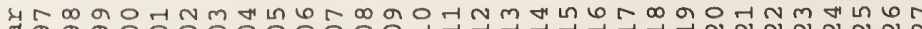

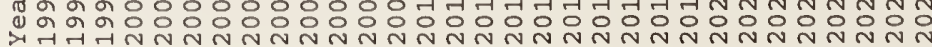




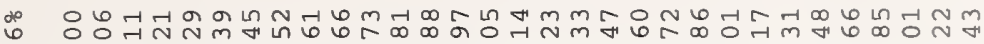
-i

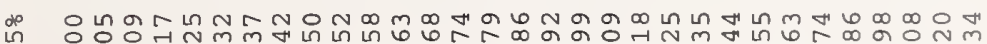

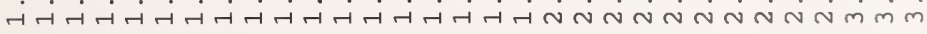

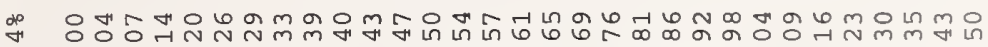

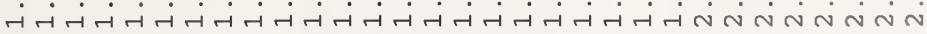

我

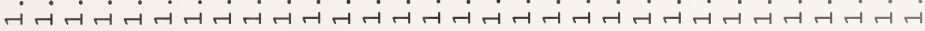

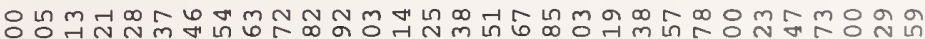
-i

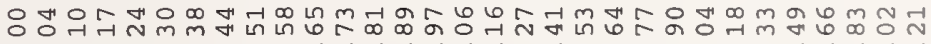

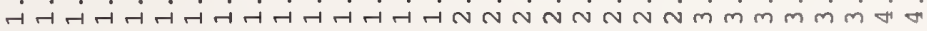

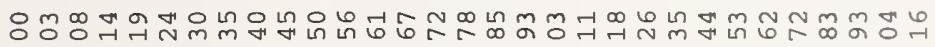
-

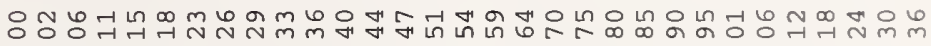

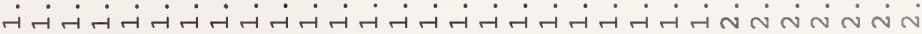

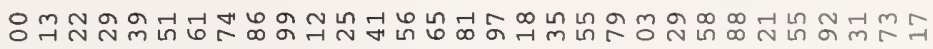
नं

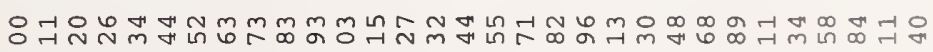

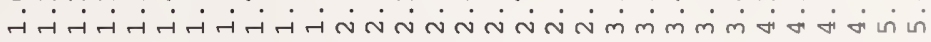

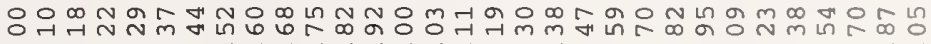

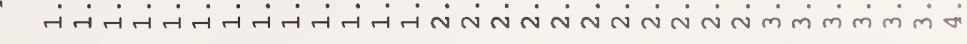

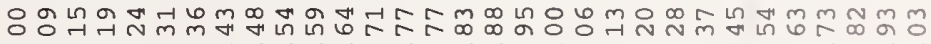

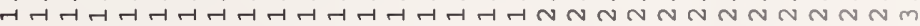

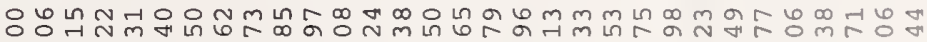

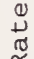

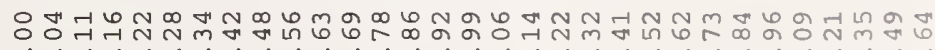
$\stackrel{\text { 㟧 }}{ }$

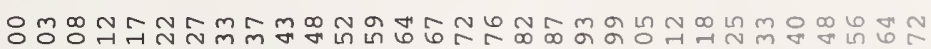
4.

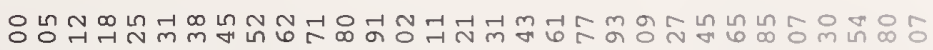

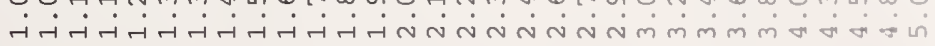

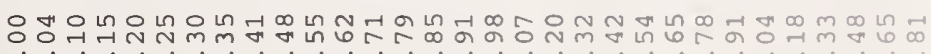

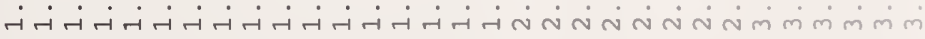




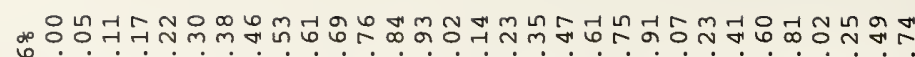

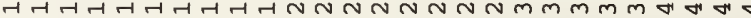
न

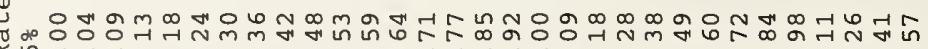

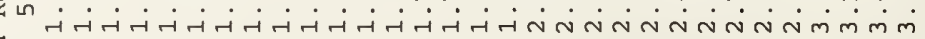
ᄃ.

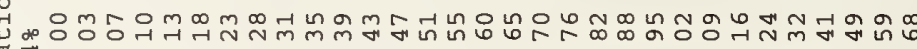

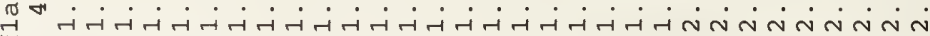
岁

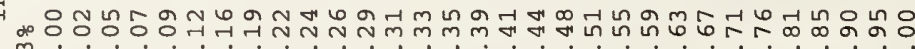

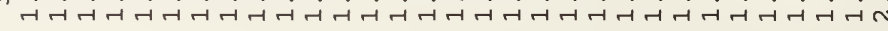

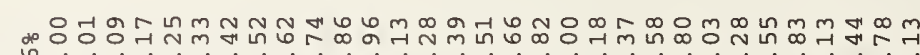
तन तन

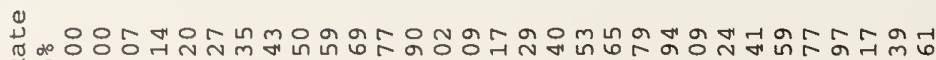
: न

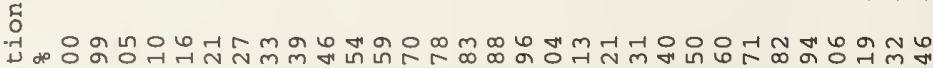

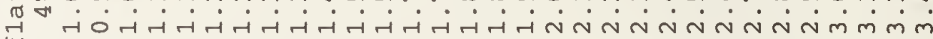
西

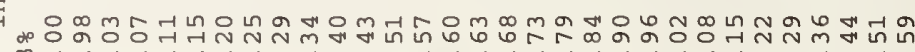

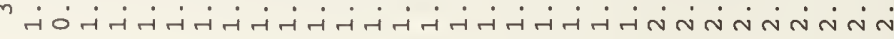

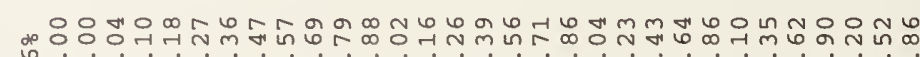

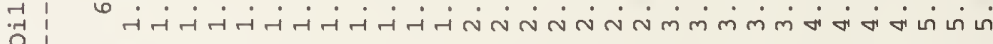

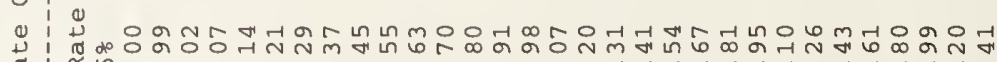
ब व $\begin{array}{lll}-\rightarrow & 5 \\ -7 & 0 & 0\end{array}$ 苟 㟧

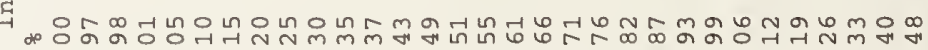

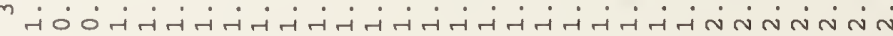

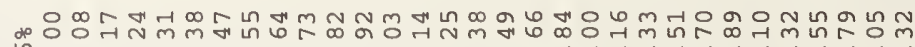

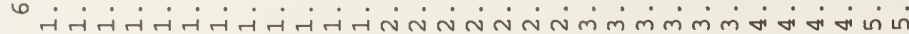
辛

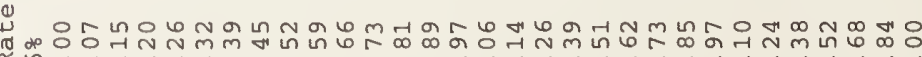

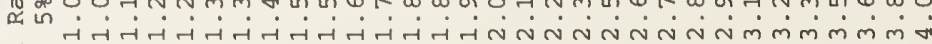
도 盖 㟧

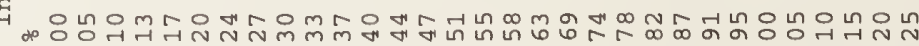

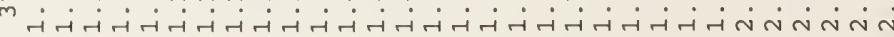




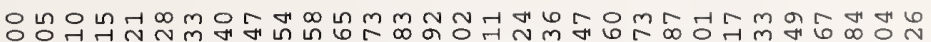

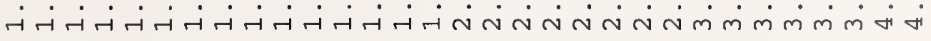

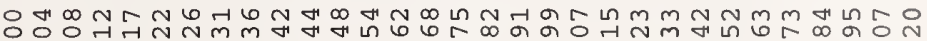
-i नi नi नi

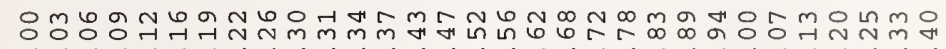

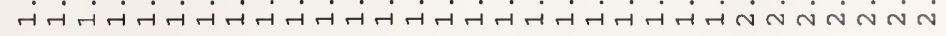

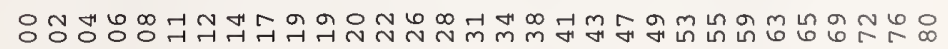

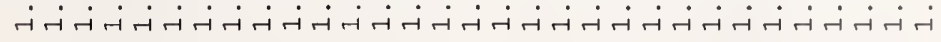

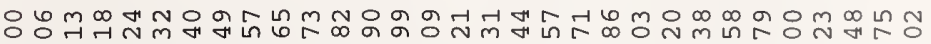

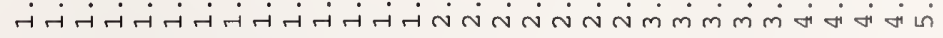

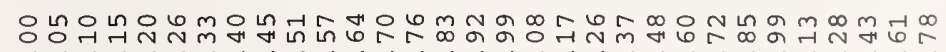

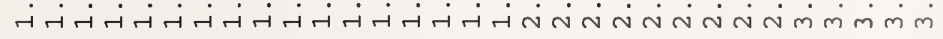

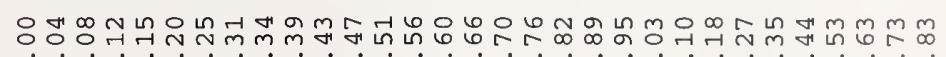

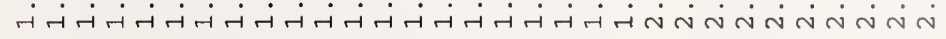

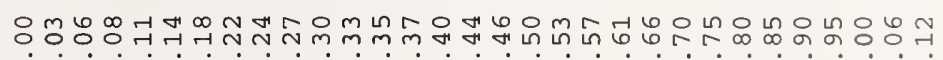
4.

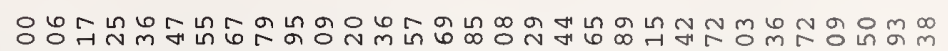

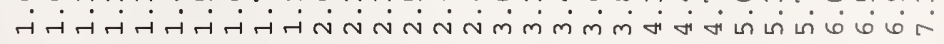

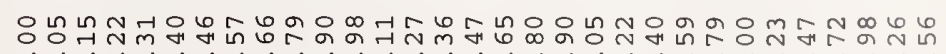

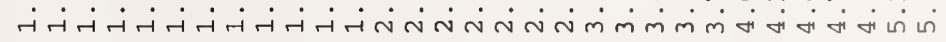

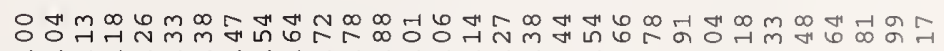

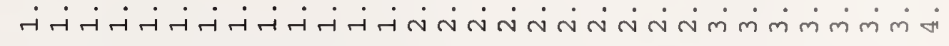

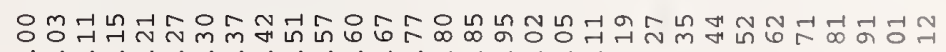
-i नi

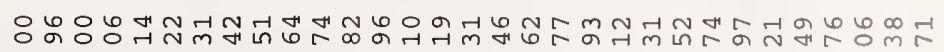

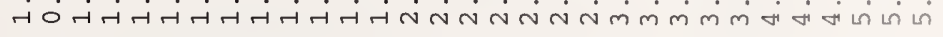

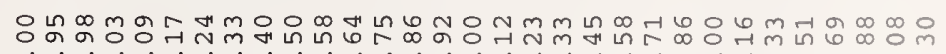

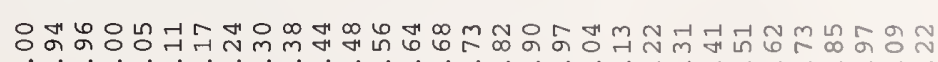

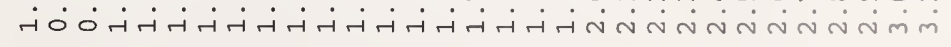

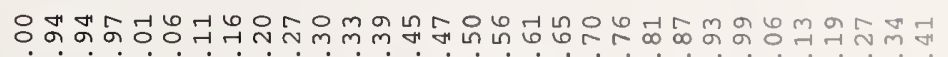
-000न

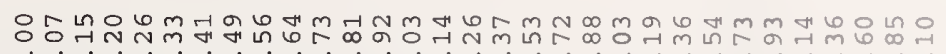

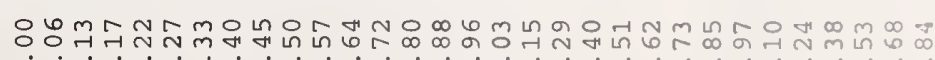

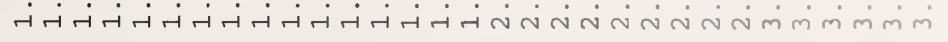

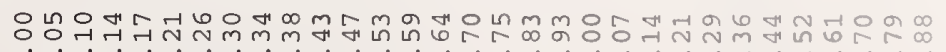

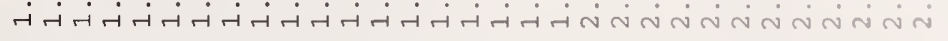




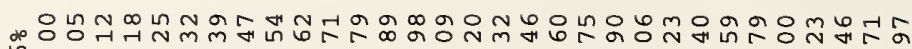

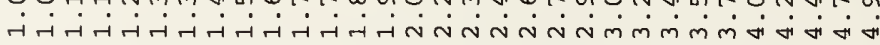
嵌 绻 द्व

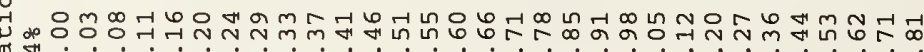

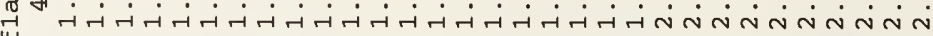
$\stackrel{\text { 壵 }}{1}$

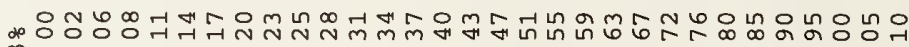

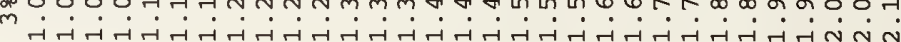

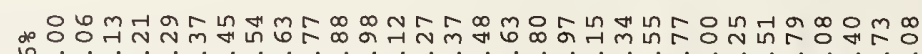

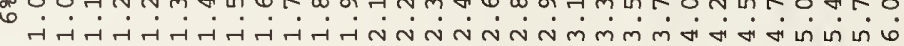
嵌 i हิ

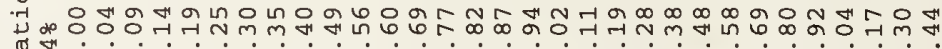
-

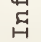

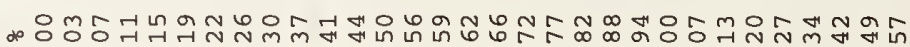

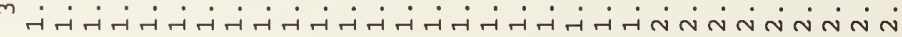

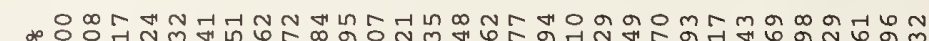

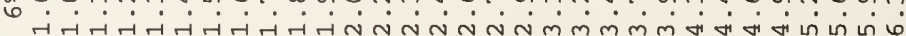

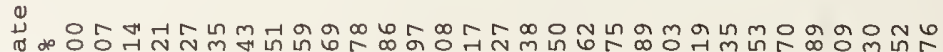

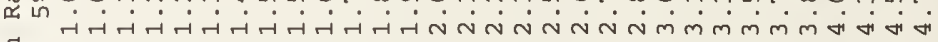
นี

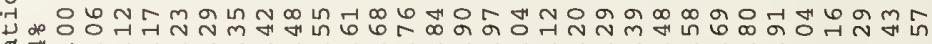
त 西

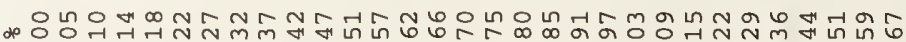

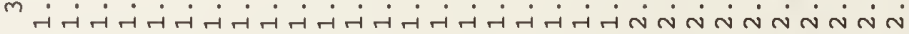

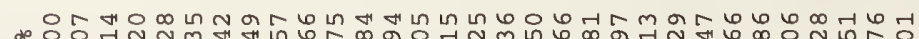

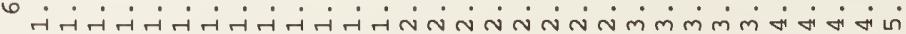
嵌

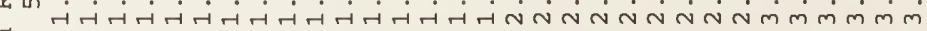
도

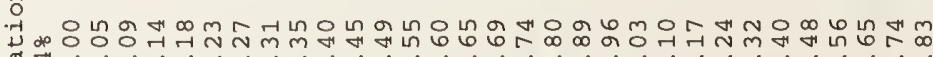

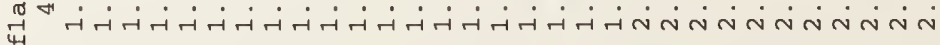
岸

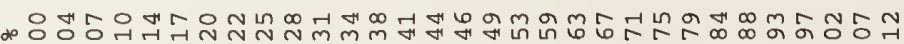
m

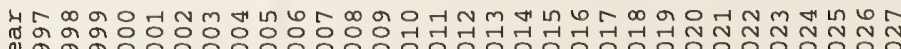
v 


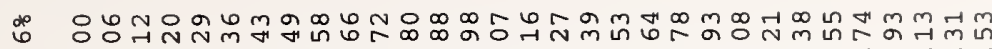

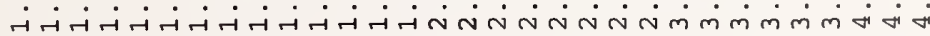

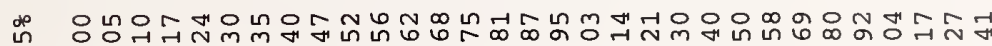

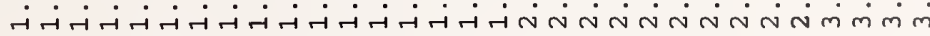

শ

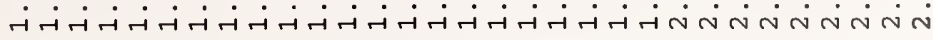

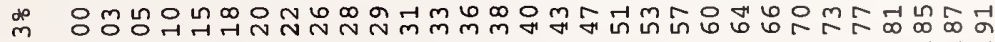

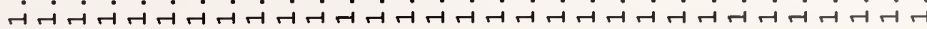

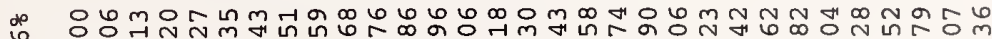

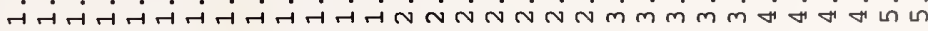

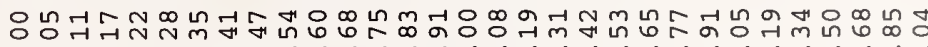

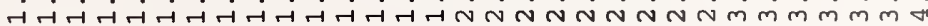

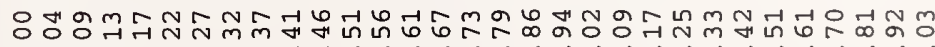
तं

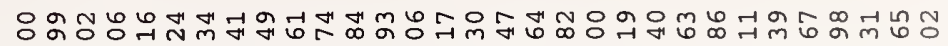

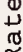

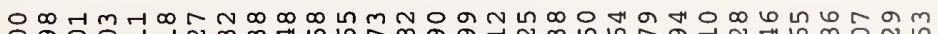

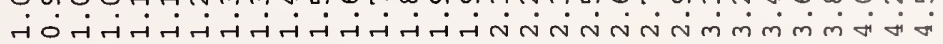

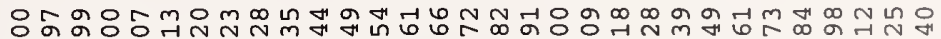

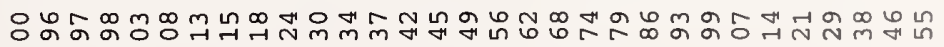

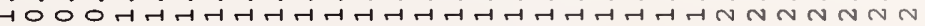

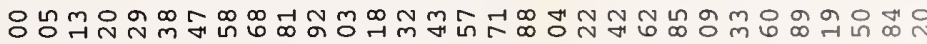

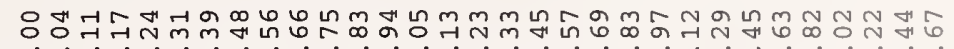

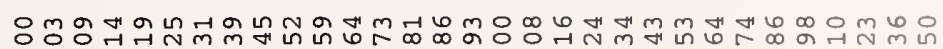

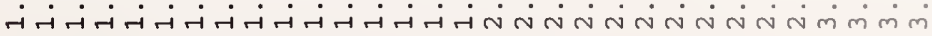

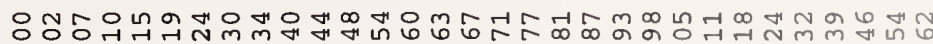

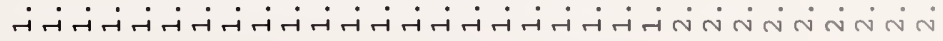

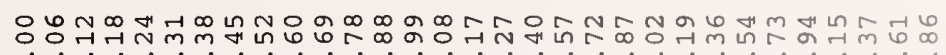

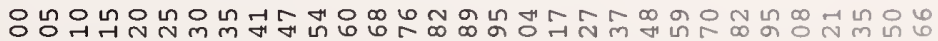

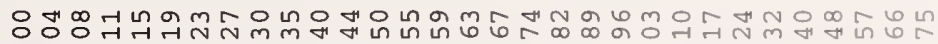

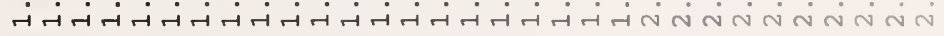




